\title{
Looking for the undiscovered asexual taxa: case studies from lesser studied life modes and habitats
}

Wijayawardene $\mathrm{NN}^{1,2}$, Phillips $\mathrm{AJL}^{3}$, Tibpromma $\mathrm{S}^{4,5}$, Dai $\mathrm{DQ}^{1, *}$, Selbmann $\mathrm{L}^{6,7}$, Monteiro $\mathbf{J S}^{\mathbf{8}}$, Aptroot $\mathrm{A}^{\mathbf{9}}$, Flakus $\mathrm{A}^{\mathbf{1 0}}$, Rajeshkumar $\mathrm{KC}^{\mathbf{1 1}}$, Coleine $\mathrm{C}^{\mathbf{6}}$, Pereira DS $^{3}$, Fan $\mathrm{X}^{12}$, Zhang L ${ }^{12}$, Maharachchikumbura $\mathrm{SSN}^{13}$, Souza $\mathrm{MF}^{9}$, Kukwa $\mathrm{M}^{14}$, Suwannarach $\mathbf{N}^{15}$, Rodriguez-Flakus $\mathbf{P}^{10}$, Ashtekar $\mathbf{N}^{11}$, Dauner $\mathbf{L}^{5}$, Tang $\mathbf{L} Z^{16}$,*, Jin $\mathrm{XC}^{1}$ and Karunarathna SC $\mathrm{SC}^{4,5, *}$

\footnotetext{
${ }^{1}$ Center for Yunnan Plateau Biological Resources Protection and Utilization, College of Biological Resource and Food Engineering, Qujing Normal University, Qujing, Yunnan 655011, P.R. China

${ }^{2}$ Section of Genetics, Institute for Research and Development in Health and Social Care, No: 393/3, Lily Avenue, Off Robert Gunawardane Mawatha, Battaramulla 10120, Sri Lanka

${ }^{3}$ Universidade de Lisboa, Faculdade de Ciências, Biosystems and Integrative Sciences Institute (BioISI), Campo Grande, 1749-016 Lisbon, Portugal

${ }^{4}$ CIFOR-ICRAF, World Agroforestry Centre, Kunming 650201, Yunnan, P.R. China

${ }^{5}$ Centre for Mountain Futures (CMF), Kunming Institute of Botany, Kunming, Yunnan, 650201, P.R. China

${ }^{6}$ Department of Ecological and Biological Sciences, University of Tuscia, Viterbo, Italy

${ }^{7}$ Italian National Antarctic Museum (MNA), Mycological Section, Genoa, Italy

${ }^{8}$ Coordination of Botany, Museu Paraense Emílio Goeldi, 66077830, Belém, PA, Brazil/Instituto Tecnológico Vale, Rua Boaventura da Silva, 955, Nazaré, 66055-090, Belém, PA, Brazil

${ }^{9}$ Laboratório de Botânica/Liquenologia, Instituto de Biociências, Universidade Federal de Mato Grosso do Sul, Avenida Costa e Silva s/n, Bairro Universitário, CEP 79070-900, Campo Grande, MS, Brazil

${ }^{10}$ W. Szafer Institute of Botany, Polish Academy of Sciences, Lubicz 46, PL-31-512 Krakow, Poland

${ }^{11}$ National Fungal Culture Collection of India (NFCCI), Biodiversity and Palaeobiology Group, MACS Agharkar Research Institute, G. G. Agarkar Road, Pune 411004, India

${ }^{12}$ The Key Laboratory for Silviculture and Conservation of Ministry of Education, Beijing Forestry University, Beijing 100083, P.R. China

${ }^{13}$ School of Life Science and Technology, Center for Informational Biology, University of Electronic Science and Technology of China, Chengdu 611731, P.R. China

${ }^{14}$ Department of Plant Taxonomy and Nature Conservation, Faculty of Biology, University of Gdańsk, Wita Stwosza 59, PL-80-308 Gdańsk, Poland

${ }^{15}$ Research Center of Microbial Diversity and Sustainable Utilization, Faculty of Science, Chiang Mai University, Chiang Mai, 50200, Thailand

${ }^{16}$ College of Life Sciences, Jiangxi Normal University, Jiangxi 330022, P.R. China
}

Wijayawardene NN, Phillips AJL, Tibpromma S, Dai DQ, Selbmann L, Monteiro JS, Aptroot A, Flakus A, Rajeshkumar KC, Coleine C, Pereira DS, Fan X, Zhang L, Maharachchikumbura SSN, Souza MF, Kukwa M, Suwannarach N, Rodriguez-Flakus P, Ashtekar N, Dauner L, Tang LZ, Jin XC, Karunarathna SC 2021 - Looking for the undiscovered asexual taxa; case studies from lesser studied life modes and habitats. Mycosphere 12(1), 1290-1333, Doi 10.5943/mycosphere/12/1/17

\section{Abstract}

Fungi are vital functional members of the biosphere, playing a crucial role in sustaining ecosystems by maintaining the nutrient balance. Many studies have verified the abundance of fungi across all-natural ecosystems and habitats, such as in forests, fresh-water (including both lentic or 
lotic), marine environments and deserts. With the focus previously on temperate regions and to a lesser extent biodiversity hotspots, the fungi in other areas remain overlooked. Therefore, it is imperative for mycologists to focus on taxa from these less-studied habitats, those dwelling on a vast number of hosts, and fungi that co-exist with other life forms. Molecular tools have been vital for species identification, in phylogeny, and linking sexual and asexual morphs. Identification of taxa based on the phylogenetic species concept, which relies on multiple loci and concordance of more than one gene genealogy, reduces subjectivity when determining the limits of a phylogenetic species. Large numbers of fungi inhabit biodiversity hotspots; however, they are underexplored owing to the vast diversity present and lack of studies. As examples of illustrating the undiscovered asexual fungi, this paper reports one new genus (Uniappendiculata Tibpromma), six new species (Caprettia lichexanthotricha Aptroot \& M.F. Souza, Hermatomyces maharashtraense Rajeshkumar et al., Lichenoconium hawksworthii Flakus et al., Phaeobotryon spiraeae L.X. Zhang \& X.L. Fan, Rachicladosporium aridum L. Selbmann \& C. Coleine and Uniappendiculata kunmingensis Tibpromma) and one new host and country record (Apiculospora spartii Wijayaw. et al.). The paper discusses the biodiversity rich areas of South-Western China, South America and India, lessstudied habitats (rock inhabiting fungi, lichens with conidiomata and lichenicolous fungi), and geographically widespread, but lesser studied hosts to show substantial studies are needed to reveal the extent of fungal diversity. The impact of discovering cryptic species on cataloguing fungal species numbers is also discussed. Each section exemplifies the status of the current research in that genus and future work that is needed.

Keywords -7 new taxa - Ascomycota - DNA sequences - fungal diversity - habitat - life modes phylogeny - taxonomy

\section{Introduction}

Predicting the number of species in the Kingdom Fungi is one of the many challenges of mycologists. Different studies have addressed this subject using different techniques (Hyde et al. 2018). Several studies have questioned "where are the missing fungi", looking at the trends that are being followed in order to discover novel taxa (Hyde 2001, Jeewon \& Hyde 2007, Hawksworth \& Lücking 2017, Hyde et al. 2020). An estimated $20 \%$ of taxa reproduce asexually, and are reported as asexually typified or as pleomorphic species (Wijayawardene et al. 2021c). Thus, based on the predictions of Hawksworth \& Lücking (2017) only $4 \%$ to $6.8 \%$ of estimated asexually reproducing species are presently known (Fig. 1). However, currently ca. 3653 genera (ca. 30,000 morphological species) are known from asexual reproduction (1388 coelomycetes and 2265 hyphomycetes) in their life cycle, while 687 genera are pleomorphic (305 coelomycetous; 378 hyphomycetous and four genera show both coelomycetous and hyphomycetous morphs) (Wijayawardene et al. 2021b).

Hawksworth (1991) forecasted that missing taxa could be discovered from tropical regions and poorly studied habitats, aquatic and lichenicolous fungi being provided as examples. This prediction was supported in recent studies with the discovery of hundreds of new taxa (e.g. aquatic fungi fide Luo et al. 2019, Dong et al. 2020, lichenicolous taxa fide Diederich et al. 2018, Baldrian et al. 2021). Hyde et al. (2018) demonstrated that up to $96 \%$ of fungi newly isolated in northern Thailand might be new to science, supporting the predictions of Hawksworth (1991) that many of the undiscovered taxa occur in the tropics. Hawksworth \& Lücking (2017) and Hyde et al. (2020) suggested that cryptic species and reference collections could harbour even more undescribed species. Undescribed species within already extant, but cryptic species have been reported in several publications (e.g. species complexes in Colletotrichum, Phyllosticta and Trichoderma fide Damm et al. 2009, Jayawardena et al. 2016, Norphanphoun et al. 2020, Bhunjun et al. 2021, Cai \& Druzhinina 2021). We have observed that many new taxa have been introduced from fungi-rich host genera/ families (such as Arecaceae, Clematis, Eucalyptus, Rosa, Salix, Tilia) during the last decade (e.g. Wanasinghe et al. 2018a for fungi on Rosaceae, Tibpromma et al. 2018a for fungi on 
Pandanaceae; Crous et al. 2019 for fungi on Eucalyptus, Mapook et al. 2020 fungi on Siam weed; Phukhamsakda et al. 2020 for fungi on Clematis).

This study, introduces a new genus and six new species from: 1. Biodiversity rich, understudied regions (i.e. from South Western China, South America, and India); 2. Lesser studied habitats - e.g. lichens with conidiomata, lichenicolous taxa and rock inhabiting taxa, and 3. Fungirich, geographically widespread hosts (and their families). Furthermore, cryptic species of Diaporthe Nitschke are discussed since they could comprise numerous undescribed new species.

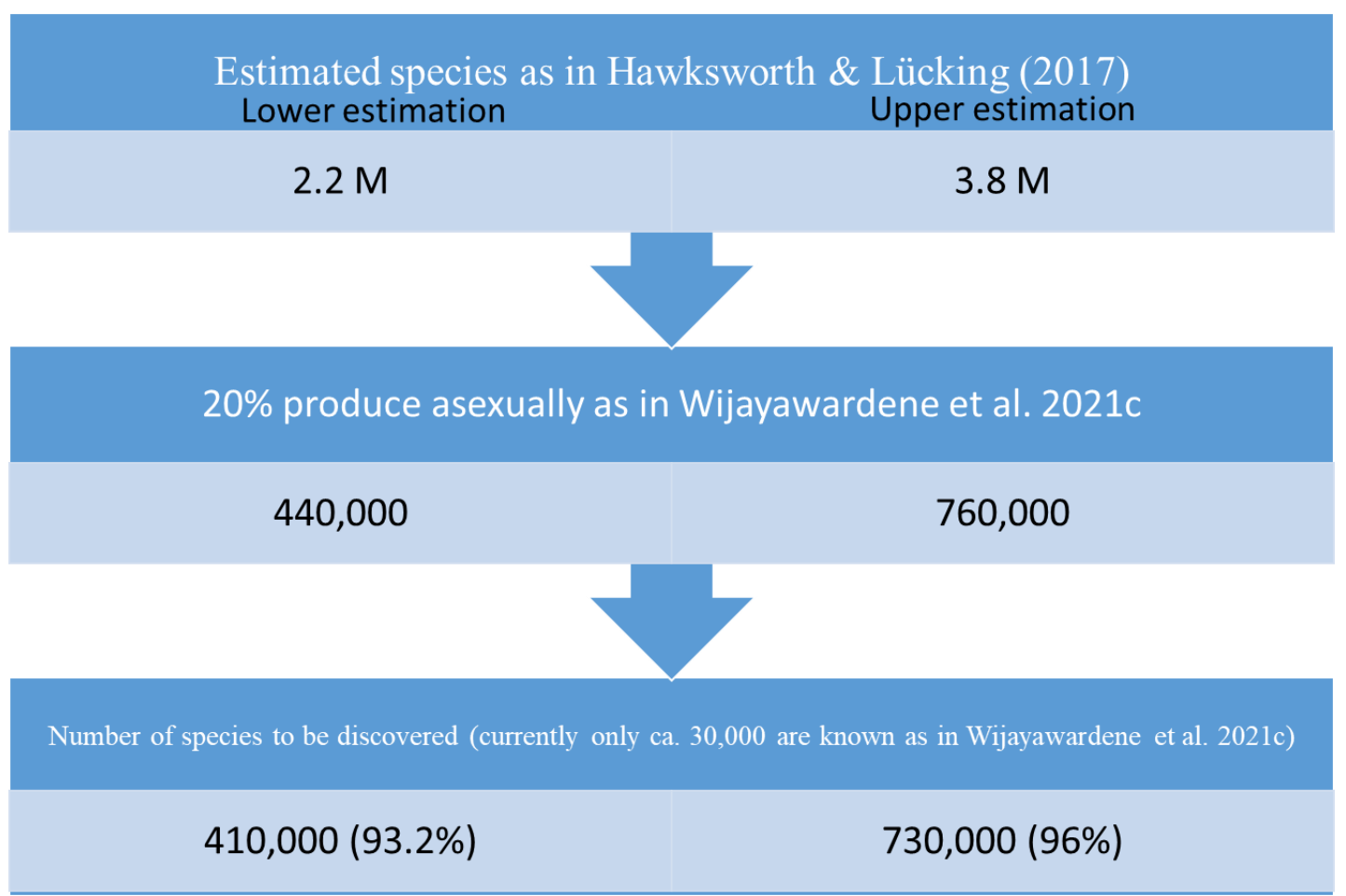

Figure 1 - Estimated species number and numbers of species to be discovered.

\section{Materials \& Methods}

\section{Sample collecting and incubating}

Living plant material with disease-like symptoms (for collecting pathogens) and dead plant material were randomly collected from different countries or regions (i.e. Antarctica, Bolivia, Brazil, China [Beijing and Yunnan Province], and India). Date, time, elevation and humidity were recorded. The samples were kept in Ziploc plastic bags and transported to the laboratory. Samples were sealed and incubated at room temperature in moist chambers using sterile distilled water.

\section{Isolation, examination and maintenance of specimens and cultures}

Single spore isolation method was used to isolate the fungus (Chomnunti et al. 2011). Conidiomata were sectioned with a razor blade, and the centrum tissue containing conidia was removed with a sterile needle and placed in sterile water. For hyphomycetous taxa, conidiophores were picked off and placed in sterilised water. A drop of conidial suspension was placed on water agar (WA) $1.5 \%$ and incubated overnight at room temperature. The germinated spores were transferred to potato dextrose agar (PDA). The dry specimens were deposited at well-known fungaria of the respective countries, and the cultures were deposited at the culture collections in the respective countries.

Morphological characteristicswere captured with a digital camera (Nikon ECLIPSE 80i) mounted on a Nikon ECLIPSE Ni compound microscope equipped with DIC optics. A digital 
camera (HDMI 200C) on an Olympus SZH10 stereomicroscope was used to capture images of macro-morphological characters.

Squash mount preparations were used to determine micromorphology (conidiophores, conidiogenous cells, conidia) (Sutton 1980). Free-hand sections were made to observe the shape of conidiomata and cell arrangement of the conidiomata wall. Conidiophores attached with conidiogenous cells and conidia were placed in water drop to determine the morphological characters of hyphomycetous taxa. Observed characteristics were presented as photo plates that were edited and combined in Adobe Photoshop version CS5 (Adobe Systems Inc., United States). Morphological characteristics were measured using Tarosoft $(\mathrm{R})$ Image Frame Work version 0.9.7.

\section{DNA extraction, PCR and sequencing}

Genomic DNA was extracted from fresh mycelia grown on PDA at $25-27^{\circ} \mathrm{C}$ using the Biospin Fungus Genomic DNA Extraction Kit (BioFlux ${ }^{\circledR}$, Hangzhou, and P.R. China) according to the manufacturer's instructions. LSU, SSU, ITS, tefl- $\alpha$ and $r p b 2$ genes were amplified by polymerase chain reaction (PCR) using LR0R/LR5, NS1/NS4 and ITS5/ITS4 primers, respectively (Table 1). PCR products were sequenced by Shanghai Sangon Biological Engineering Technology \& Services Co. (Shanghai, P.R. China). Newly generated sequences were deposited in GenBank.

Table 1 Loci, PCR primers, references and protocols used in this study.

\begin{tabular}{llll}
\hline Gene region & \multicolumn{1}{c}{ Primers } & \multicolumn{1}{c}{ Thermal cycles } & \multicolumn{1}{c}{ Reference } \\
\hline ITS & ITS5/ ITS4 & $\left(95^{\circ} \mathrm{C}: 30 \mathrm{~s}, 55^{\circ} \mathrm{C}: 50 \mathrm{~s}\right.$, & White et al. (1990) \\
& & $\left.72^{\circ} \mathrm{C}: 90 \mathrm{~s}\right) \times 35$ cycles & \\
LSU & LR0R/ LR5 & $\left(95^{\circ} \mathrm{C}: 30 \mathrm{~s}, 55^{\circ} \mathrm{C}: 50 \mathrm{~s}\right.$, & Vilgalys et al. (1990), \\
& & $\left.72^{\circ} \mathrm{C}: 90 \mathrm{~s}\right) \times 35$ cycles & Rehner \& Samuels (1994) \\
SSU & NS1/ NS4 & $\left(95^{\circ} \mathrm{C}: 30 \mathrm{~s}, 55^{\circ} \mathrm{C}: 50 \mathrm{~s}\right.$, & White et al. (1990) \\
& & $\left.72^{\circ} \mathrm{C}: 90 \mathrm{~s}\right) \times 35$ cycles & \\
$\boldsymbol{t e f 1 - \alpha}$ & EF1-983F/ EF1-2218R & $\left(94^{\circ} \mathrm{C}: 45 \mathrm{~s}, 56^{\circ} \mathrm{C}: 50 \mathrm{~s}\right.$, & Rehner (2001) \\
& & $\left.72^{\circ} \mathrm{C}: 60 \mathrm{~s}\right) \times 40$ & \\
$\boldsymbol{r p b 2}$ & RPB2-5F/ RPB2-7cR & $\left(\right.$ Touch up PCR: $50^{\circ} \mathrm{C}: 30 \mathrm{~s}$, & Liu et al. (1999) \\
& & $72^{\circ} \mathrm{C}: 90 \mathrm{~s} ; 30 \mathrm{cycles}$ with $95^{\circ} \mathrm{C}:$ & \\
& & 1 min, $52^{\circ} \mathrm{C}: 30 \mathrm{~s}, 72^{\circ} \mathrm{C}: 90 \mathrm{~s} ;$ & \\
& nine cycles of $95^{\circ} \mathrm{C}: 1 \mathrm{~min}$, & \\
& $\left.55^{\circ} \mathrm{C}: 30 \mathrm{~s}, 72^{\circ} \mathrm{C}: 90 \mathrm{~s}\right)$ & \\
& &
\end{tabular}

\section{Phylogenetic analyses}

Phylogenetic analyses were based on the combined multiple loci following the methods reported in the literature. Single locus alignments were carried out to compare tree topologies. The combined locus sequence matrices comprised newly generated sequences and related sequences obtained from GenBank. Sequences were combined and aligned in Mega 6.0.5 (Tamura et al. 2013) and MAFFT multiple sequence alignment software version 7.215 (Katoh et al. 2019), and were manually improved when necessary. Phylogenetic analyses were made using maximum likelihood (ML), maximum parsimony (MP) and Bayesian inference (BI).

ML was performed in RaxmlGUI v.1.3 (Silvestro \& Michalak 2012) with 1000 thorough bootstrap replicates. A generalized time-reversible (GTR) for nucleotides was applied with a discrete gamma distribution (Silvestro \& Michalak 2012). Rapid bootstrap analysis (Stamatakis 2014) and a search for a best-scoring ML tree were applied (Silvestro \& Michalak 2012).

BI was performed with MrBayes v. 3.1.2 (Ronquist \& Huelsenbeck 2003) and the best-fit model of sequences evolution was estimated with MrModeltest 2.2 (Nylander et al. 2004). Markov chain Monte Carlo sampling (MCMC) was used to determine the posterior probabilities (PP) (Rannala \& Yang 1996, Zhaxybayeva et al. 2006). Six simultaneous Markov chains were run for 1000000 to 5000000 generations and halted automatically when the standard deviation of split frequencies was less than 0.01 . Trees were sampled every 1000 th generation. The first $20 \%$ of trees 
were discarded as the burn-in phase. The remaining trees were used to calculate the posterior probability (PP).

\section{Results \& discussion}

In this section, we introduce one new genus and nine new species from lesser-studied habitats, biodiversity rich tropical regions and under-explored regions, lesser studied habitats and from a fungi-rich host family (e.g. Rosaceae). Each section provides the status of the current research, and predictions for future species numbers.

\section{Biodiversity-rich, tropical and under explored regions}

Biodiversity comprises three main components, ecosystem diversity, species diversity and genetic diversity (DeLong 1996). Smith et al. (2003) noted that the discovery of novel taxa is hampered by the fact that much of the world's biodiversity resides in developing countries that lack proper funding for taxonomic studies. However, the development of fungal diversity research in biodiversity-rich, Asian countries (such as China, India, Japan, Malaysia and Thailand) is remarkable in the last two decades (Hyde et al. 2020). Long term, organised studies in some regions in tropical countries, confirm higher fungal diversity than was expected (e.g. Northern Thailand fide Hyde et al. 2018). Nevertheless, in some biodiversity-rich countries such as Sri Lanka (Myers et al. 2000), the number of taxonomic studies are few, and thus, knowledge is poor. As an example, Wijayawardene et al. (2021d) suggested Sri Lanka may harbour more than 33,000 species (per new host: fungi ratio; 1:9.8 fide Hawksworth \& Lücking 2017) but currently only ca. 3000 are known (Adikaram \& Yakandawala 2020). Moreover, fungi associated with insects in Sri Lanka has never been documented, thus, a higher number of species is expected (Wijayawardene et al. 2021c). Hyde et al. (2020) emphasized the importance of experts for carrying out taxonomic studies and surveys. Some of these biodiversity-rich, developing countries lack taxonomists or working groups like other developed countries or even similar to India, Thailand and China (Hyde et al. 2020). This was accepted by Wijayawardene et al. (2021d), who showed that out of 1716 species originally described in Sri Lanka, 1511 were described by British mycologists prior to 1958. Studies which are supported by DNA sequence analyses, are also lacking in most of these tropical, developing countries thus, cryptic diversity is overlooked.

Biodiversity rich areas have been recognized as important locations to discover fungi (Hawksworth 1991, Hawksworth \& Lücking 2017, Hyde et al. 2020). The number of plants inhabiting fungi (i.e. host-fungi ratio) in tropical biodiversity rich areas may be higher than those currently known in other regions (Hawksworth \& Lücking 2017). Several studies from biodiversity rich areas (South-Western China, India, Brazil, Sri Lanka) have revealed hundreds of novel species in the last decade (Luo et al. 2019, Rajeshkumar \& Singh 2012, Rajeshkumar et al. 2019, 2021, Ferdinandez et al. 2021). These examples indicate that many new taxa will be discovered in such regions. However, it is essential to rely on DNA sequence-based species identification since some taxa could potentially represent other morphs of extant taxa (see Wijayawardene et al. 2021c).

In this section, three new taxa are introduced from biodiversity rich areas and underexplored regions, namely one new genus, Uniappendiculata Tibpromma (typified by U. kunmingensis Tibpromma), and one new host and country record, Apiculospora spartii from South-Western China (Yunnan Province); one new species, Hermatomyces maharashtraense Rajeshkumar et al. from India.

Apiculospora Wijayaw., Camporesi, A.J.L. Phillips \& K.D. Hyde, Fungal Diversity 77: 42 (2016) Index Fungorum number: IF551761; Facesoffungi number: FoF 01425

Notes - Wijayawardene et al. (2016) introduced this genus with A. spartii Wijayaw. et al. from dead branches of Spartium junceum. Apiculospora was included in Leotiomycetes, genera incertae sedis by Ekanayaka et al. (2019), although Hyde et al. (2020) transferred Apiculospora to Rhytismatales genera incertae sedis based on phylogenetics. Karunarathna et al. (2021) introduced A. penniseti from dead leaves of Pennisetum purpureum. Apiculospora currently includes two 
species (Index Fungorum 2021). Our new strain from Yunnan Province is morphologically and phylogenetically related to Apiculospora spartii(Figs 6, 7).Apiculospora species are currently reported from three hosts, Spartium junceum (Fabaceae; Italy), Pennisetum purpureum (Poaceae; Taiwan, China) and Yucca gigantea (Asparagaceae; mainland China). All these host genera have been reported with a large number of fungi (Spartium with 172 records; Pennisetum with 1891 records; Yucca with 665 records) (Farr \& Rossman 2021). Pennisetum contains 83 species and Yucca 49 species (worldflora.org.) and show cosmopolitan distribution. Spartium comprises only one species but it is reported worldwide (including Europe, Mediterranean, the middle east, tropical and temperate Asia, Africa, Australasia, USA, Central America and South America [https:/worldflora.org.; https://www.cabi.org]). We assume that many Apiculospora species are yet to be discovered since its members are not restricted to one host genus or family and are reported from temperate (Italy) and subtropical to tropical regions (Taiwan and mainland China).

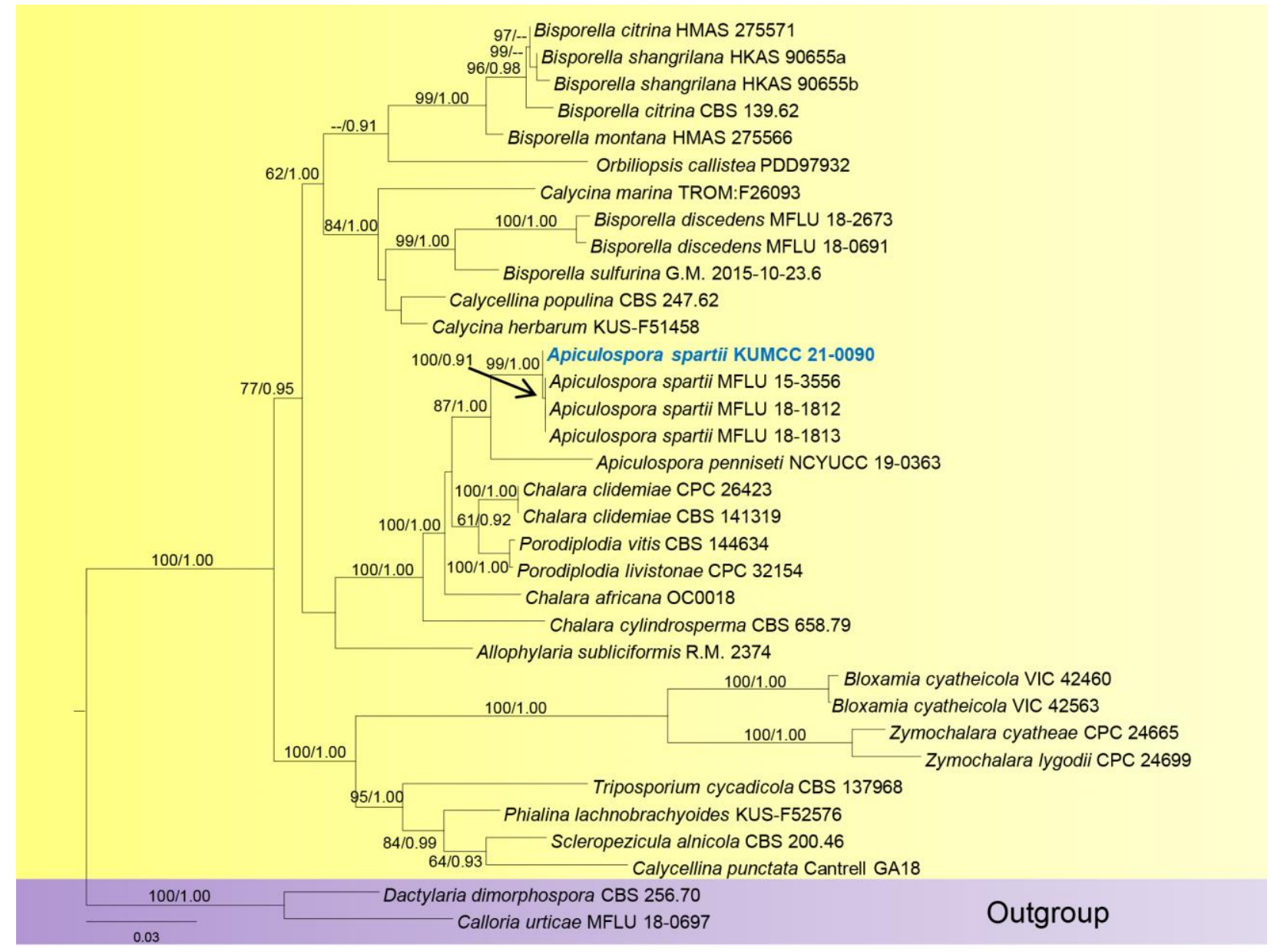

Figure 2 - The best scoring RAxML tree with a final likelihood value of -11985.843083 for combined dataset of LSU and ITS sequence data. The tree is rooted with Dactylaria dimorphospora (CBS 256.70) and Calloria urticae (MFLU 18-0697). The matrix had 627 distinct alignment patterns with $18.04 \%$ undetermined characters and gaps. Estimated base frequencies were as follows: $\mathrm{A}=0.238013, \mathrm{C}=0.236238, \mathrm{G}=0.285800, \mathrm{~T}=0.239949$; substitution rates: $\mathrm{AC}$ $=1.711489, \mathrm{AG}=2.120742, \mathrm{AT}=1.705688, \mathrm{CG}=0.816113, \mathrm{CT}=6.984196, \mathrm{GT}=1.000000$; gamma distribution shape parameter $\alpha=0.558240$. The newly generated sequence is in blue. Bootstrap support values for ML equal to or greater than $60 \%$ and BYPP equal to or greater than 0.90 are given above and below the nodes, respectively.

Apiculospora spartii Wijayaw., W.J. Li, Camporesi, A.J.L. Phillips \& K.D. Hyde 2016

Fig. 3 Index Fungorum number: IF551762; Facesoffungi number: FoF 01426 
Saprobic on dead leaves of Yucca gigantea. Sexual morph: Undetermined. Asexual morph: Conidiomata 125-155 × 145-175 $\mu \mathrm{m},(\overline{\mathrm{x}}=137 \times 161 \mu \mathrm{m}, \mathrm{n}=5)$, immersed, solitary, scattered, unilocular, subglobose, black dots, masses of spores all over the leaf surfaces of the host. Conidiomata wall 15-25 $\mu \mathrm{m}$, composed of thick-walled, orange-brown to brown cells of textura angularis; inner cell layers thin-walled, almost reduced to a conidiogenesis region. Conidiophores reduced to conidiogenous cells. Conidiogenous cells 3-10 $\times 1.5-3 \mu \mathrm{m}$, subcylindrical to ovoid, enteroblastic, with percurrent proliferation, hyaline, smooth-walled. Conidia 15-25 $\times 5-10 \mu \mathrm{m}(\overline{\mathrm{x}}=$ $22.2 \times 8.9 \mu \mathrm{m}, \mathrm{n}=40$ ), subcylindrical to ellipsoid, slightly curved, conical at apex, aseptate when immature and later become 1-septate, sometimes with a dark band at septum, sometimes constricted at septum, hyaline to pale brown when immature and later dark brown, guttulate, thickwalled non-mucilaginous.

Culture characteristics - culture on PDA, colonies slow growing, circular, spreading, flattened, flossy, smooth with entire edge, brown; reverse brown.

Material examined - Mainland, China, Yunnan Province, Kunming Institute of Botany garden (Camellia garden), dead leaves of Yucca gigantea Lem. (Asparagaceae), 7 May 2020, S. Tibpromma, ST11 (HKAS 115529); living cultures KUMCC 21-0090.

GenBank accession numbers - LSU: MZ822226; ITS: MZ822228; SSU: MZ822225.

Notes - Our collection fits with the characteristics of Apiculospora in having subcylindrical to ellipsoid conidia with a dark band at septum (Wijayawardene et al. 2016, Ekanayaka et al. 2019, Karunarathna et al. 2021). In the phylogenetic tree, our collection clusters together with A. spartii (MFLU 15-3556, MFLU 18-1812, MFLU 18-1813) with high statistical support (Fig. 2). Our collection is similar to A. spartii but only conidia size is different (Wijayawardene et al. 2016). ITS base pair differences shown only $1 \mathrm{bp}$, which suggests that our collection is identical to A. spartii. Apiculospora spartii was isolated from dead branch of Spartium junceum from Italy (Wijayawardene et al. 2016, Ekanayaka et al. 2019). We introduce our new isolate, A. spartii as a new host record from Yucca gigantea and geographical record from China.

Hermatomyces Speg., Anal. Mus. nac. B. Aires, Ser. 3 13: 445 (1910) [1911]

Hermatomyces is typified by H. tucumanensis Speg. found on fallen rotten branches of Smilax campestris and Celtis sp. in Tucumán, Argentina. It was introduced by Spegazzini (1911) with key distinguishing features of sporodochial conidiomata and muriform, lenticular, hyaline or dematiaceous, monomorphic or dimorphic conidia. Currently, the genus is only known from asexual morph characters (Spegazzini 1911, Chang 1995, Leão-Ferreira et al. 2013, Koukol et al. 2018, Tibpromma et al. 2016, 2018b, Hyde et al. 2019, Phukhamsakda et al. 2020). Hermatomycetaceae was introduced by Locquin (1984) and formalized by Hashimoto et al. (2017) based on distinctive characteristics, such as sporodochial conidiomata and two conidium types. Hermatomycetaceae was recently validated with robust phylogenetic data by Doilom et al. (2017) and Hashimoto et al. (2017) for a distinct clade of Hermatomyces species in the order Pleosporales, with Hermatomyces Speg. as the generic type. A collection of Hermatomyces from India is introduced as Hermatomyces maharashtraense sp. nov. based on morpho-molecular analyses.

Currently, 25 species (including the new species in this study) are recognized in Hermatomyces (Koukol \& Delgado 2019, Hyde et al. 2019, Nuankaew et al. 2019, Delgado et al. 2020, Phukhamsakda et al. 2020, Ren et al. 2021). We expect more species from other understudied regions and even in the regions where the species are reported.

Hermatomyces maharashtraense Rajeshkumar, Wijayaw., N. Ashtekar, S. Lad \& G. Anand, sp. nov.

Index Fungorum number: IF558559; Facesoffungi number: FoF 10419

Fig. 4

Etymology - named after Maharashtra State, where this fungus is native.

Holotype - AMH 10303, on unidentified decaying wood 

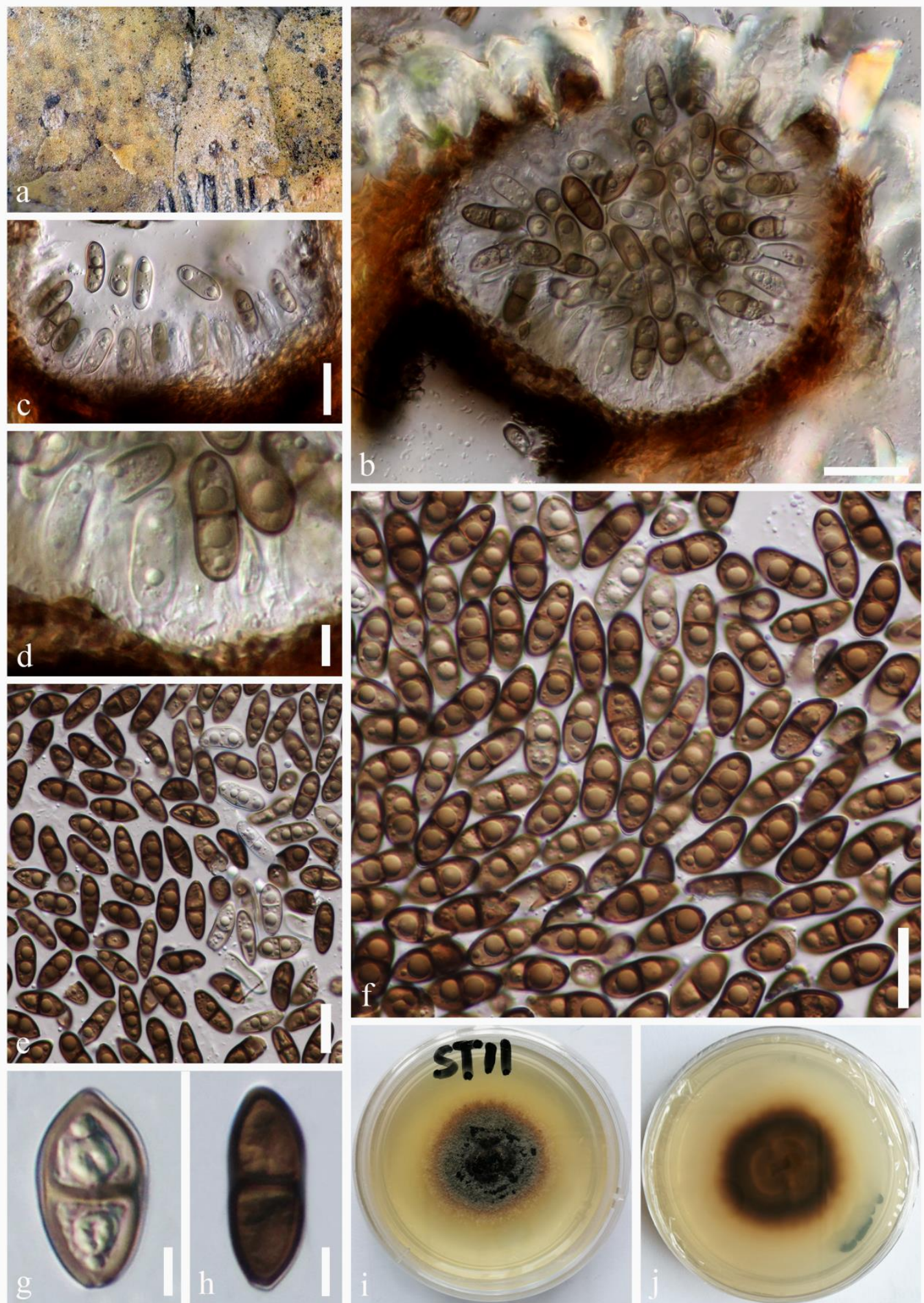

Figure 3 - Apiculospora spartii (HKAS 115529, new host and geographical record). a Conidiomata on dead leaves of Yucca gigantea. b Longitudinal section of conidioma. c, d Different stages of developing conidia attach to conidiogenous cells. e- $\mathrm{h}$ Conidia. i, j Colony characteristics on PDA medium (14 days old culture). Scale bars: $\mathrm{b}, \mathrm{e}, \mathrm{f}=20 \mu \mathrm{m}, \mathrm{c}, \mathrm{g}, \mathrm{h}=5 \mu \mathrm{m}$, $\mathrm{d}=10 \mu \mathrm{m}$.

Mycelium mostly superficial or immersed, composed of a loose or compact network of repent, branched, septate, rough and thick-walled, pale to dark brown hyphae. Sexual morph: Undetermined. Asexual morph: Colonies on natural substrate forming sporodochial conidiomata, 
subiculate, superficial, scattered, circular or oval, blackish brown, velvety. Conidiophores macronematous, mononematous, simple, straight or flexuous, septate, smooth, hyaline to pale brown, often corresponding to conidiogenous cells, 33-53 $\mu \mathrm{m}$ long, 5-10.5 $\mu \mathrm{m}$ wide. Conidiogenous cells monoblastic, integrated, terminal, determinate, cylindrical, smooth, hyaline. Conidia monomorphic, lenticular, thick-walled, globose or subglobose in front view, broadly ellipsoidal in lateral view, smooth, solitary, dry, muriform, divided longitudinally into two halves, constricted at both ends, occasionally slightly constricted at some septa, often carrying remnant of conidiogenous cell at base, 49-60 $\mu \mathrm{m}$ long, 35-55.5 $\mu \mathrm{m}$ wide. Conidia are bunched in a layer of hyaline globose or bubble-like basal cells of sporodochia, single or in chain, 20-27.5 $\mu \mathrm{m}$ diam.

Culture characteristics - Colonies on MEA at $25 \pm 2{ }^{\circ} \mathrm{C}$ after 7 days, grey to grey-brown, 15-25 mm diam., reverse dark brown to black.

Material examined - India, Maharashtra, Mulshi, on dead wood, 23 July 2018, Rajeshkumar \& Sneha Lad, holotype AMH 10303; ex-type living culture NFCCI 4879; ibid., NFCCI 4880.

GenBank accession numbers - NFCCI 4879; LSU: MZ099917 ITS: MZ147016 tefl- $\alpha$ : MZ130659 rpb2: MZ130660. NFCCI 4880; LSU: MZ147042 ITS: MZ147019 tef1-a: MZ130661 rpb2: MZ130662.

Notes - Hermatomyces maharashtraense is similar to $H$. trangensis in having a single type of lenticular conidia, globose or subglobose in front view and broadly ellipsoidal or oblong in lateral view, smooth-walled and sporulating profusely in culture. The conidial dimensions of $H$. maharashtraense are however, significantly larger than $H$. trangensis $(49-60 \times 35-55.5 \mu \mathrm{m}$ vs. 27.5-35 $\times$ 25-32.5 $\mu \mathrm{m})$. Hermatomyces clematidis is dimorphic and differs from $H$. maharashtraense in its smaller, 30-45 $\times 24-31 \mu \mathrm{m}$ conidia. Phylogeny of $H$. maharashtraense is based on ITS, LSU (not shown), and secondary barcode genes tefl- $\alpha$ and $r p b 2$. Even though the ITS region poorly resolves Hermatomyces species, LSU and combined tefl- $\alpha$ and $r p b 2$ analyses established an independent lineage of the new species closely allied to $H$. clematidis and $H$. trangensis (Fig. 5).

Uniappendiculata Tibpromma, gen. nov.

Index Fungorum Number: IF558615; Facesoffungi number: FoF 10421

Etymology - Referring to the single appendage conidia.

Type species - Uniappendiculata kunmingensis

Saprobic dead stem of Acer palmatum. Sexual morph: Undetermined. Asexual morph: Conidiomata acervular, superficial, solitary, scattered, setae formed on cushions of brown to black. Conidiophores hyaline, simple or septate, branched, smooth-walled. Conidiogenous cells enteroblastic, phialidic, hyaline, smooth-walled, cylindrical, ellipsoidal. Conidia subcylindrical, slightly curved, obtuse at apex, multi-septate, sometimes constricted at septum, hyaline, guttulate, thick-walled, with one appendage at each end.

Notes - Sulcatisporaceae was introduced by Tanaka et al. (2015) to accommodate Magnicamarosporium, Neobambusicola and Sulcatispora in Pleosporales. Sexual morphs of Sulcatisporaceae are characterized by immersed to erumpent, subglobose to hemisphaerical ascomata, short ostiolar necks, trabeculate pseudoparaphyses, clavate, broadly fusiform ascospores with hyaline, septate and mucilaginous appendages (Liew et al. 2000, Tanaka et al. 2015). The asexual morph has pycnidial conidiomata with various conidial characteristics (Tanaka et al. 2015, Phukhamsakda et al. 2017, 2020, Rupcic et al. 2018). Phylogenetic analysis of ITS, tefl- $\alpha$ and LSU sequence data indicates that one new collection from Yunnan, China, is a distinct genus in Sulcatisporaceae, which forms a clade sister to Pseudobambusicola (Fig. 6). However, Pseudobambusicola forms micro and macroconidia but our new genus forms only macroconidia. Based on morphology show macroconidia of Pseudobambusicola in having fusoid-ellipsoid, prominently guttulate, hyaline, smooth, 0-3-septate which differ from our new genus (Rupcic et al. 2018). A comparison of ITS, LSU and tefl- $\alpha$ gene regions indicate $50 \mathrm{bp}$ (ITS), $12 \mathrm{bp}$ (LSU), $52 \mathrm{bp}$ (tefl- $\alpha$ ) differences between the type species of Pseudobambusicola (BCC 79462) with our new 
genus. Hence, the new genus, Uniappendiculata is herein introduced. Uniappendiculata can be distinguished from other members in Sulcatisporaceae by subcylindrical, multi-septate, hyaline conidia with one appendage at each end.

Acer species are widely grown as ornamental plants and reported with numerous fungi (Sutton 1980, Nag Raj 1993, Farr \& Rossman 2021). Currently, 367 records of microfungi inhabiting Acer have been reported from China (Farr \& Rossman 2021). However, we predict that a large number of novel taxa are yet to be discovered from Acer species in South-Western China.
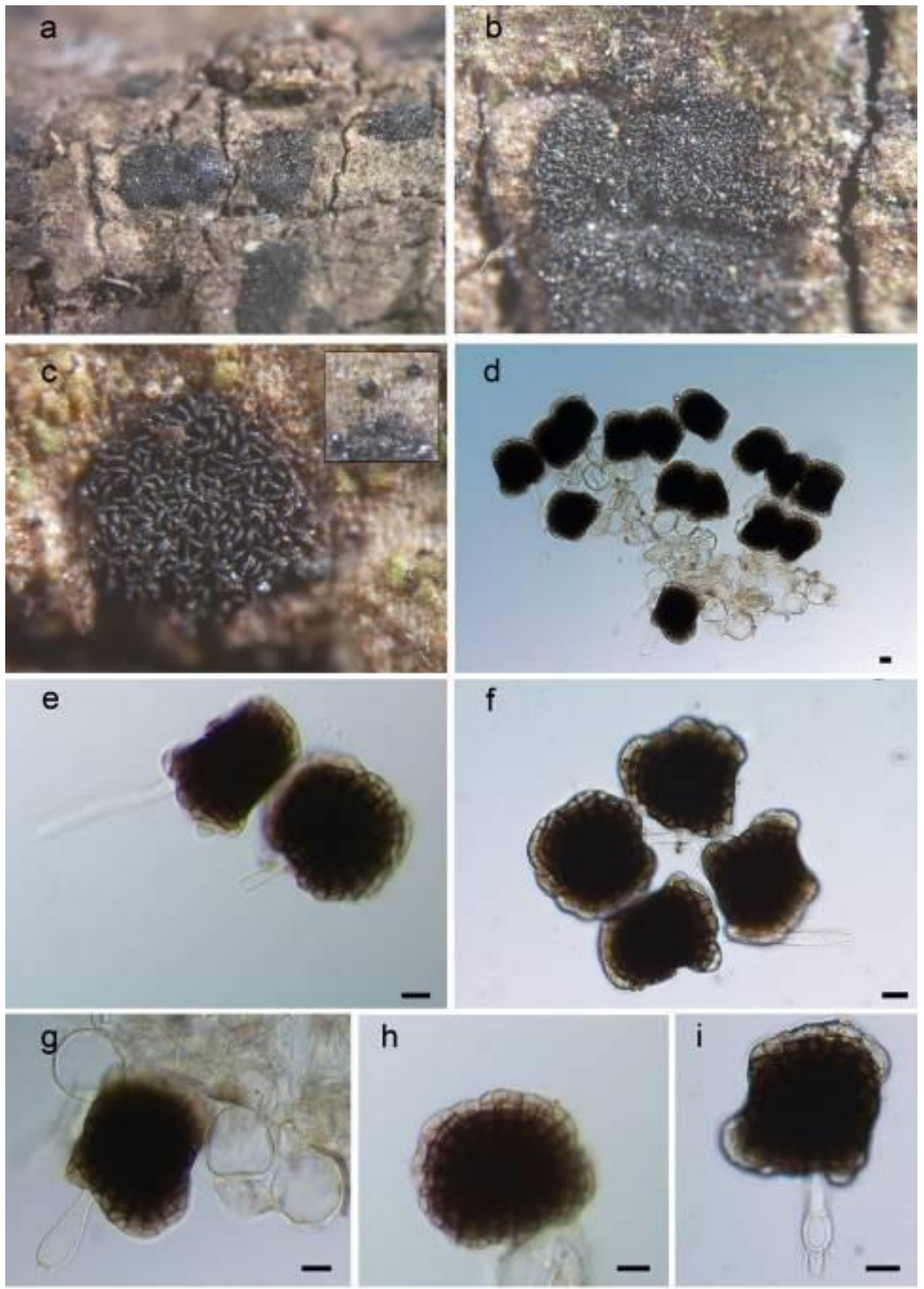

Figure 4 - Hermatomyces maharashtraense (AMH 10303, holotype). a-c Sporodochial conidiomata (c inset conidia front view). d Conidia with hyaline globose basal cells. e-i Mature conidia front view with basal attachment. Scale bars $=10 \mu \mathrm{m}$. 


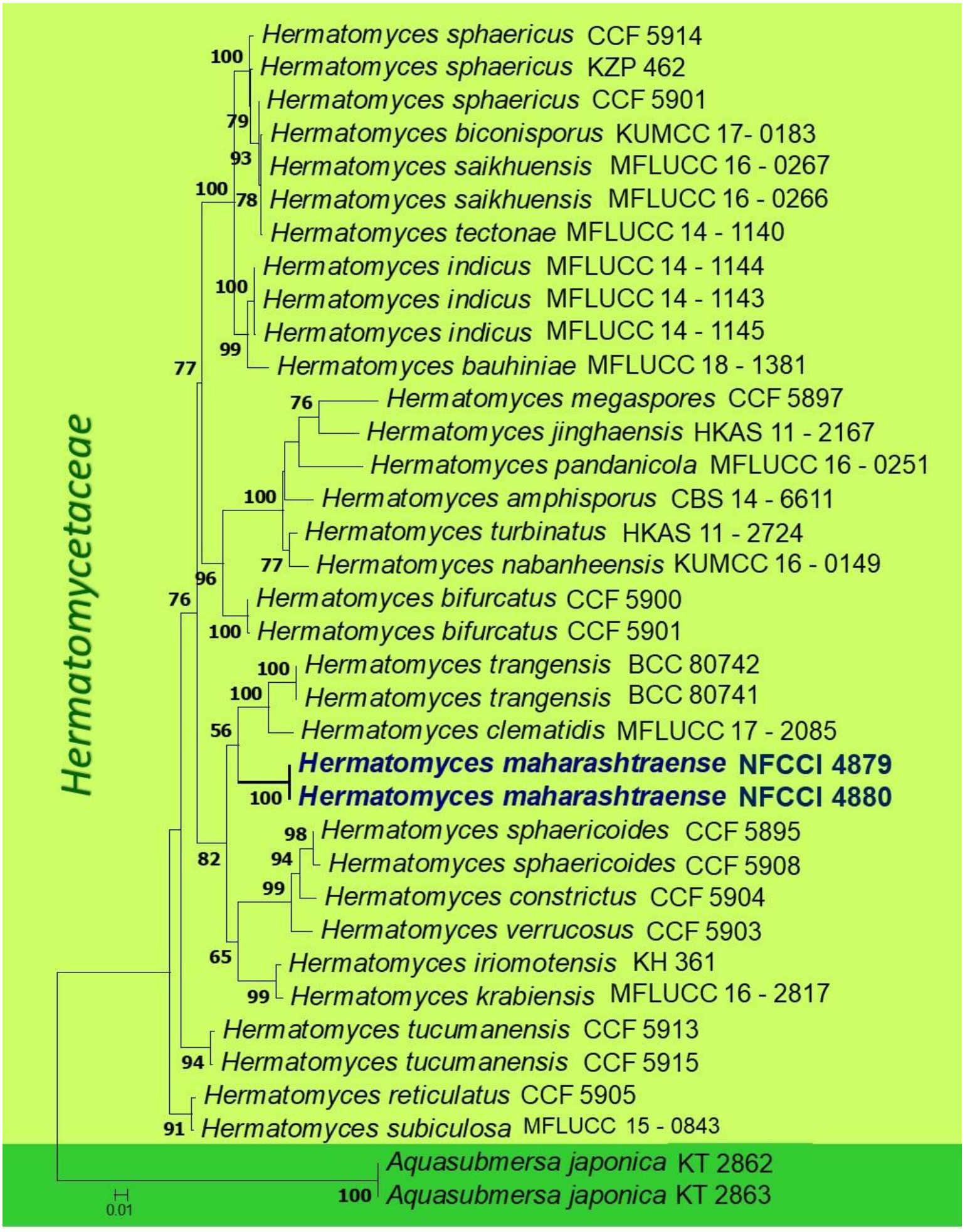

$\stackrel{H}{0.01}$

Figure 5 - The phylogram was generated from RAxML analysis based on a combined tefl- $\alpha$ and $r p b 2$ sequence data for the genus Hermatomyces (Hermatomycetaceae) with a final likelihood value of -4508.434349 . The matrix had 285 distinct alignment patterns with $1.50 \%$ undetermined characters and gaps. Estimated base frequencies were as follows: $\mathrm{A}=0.265347, \mathrm{C}=0.277374, \mathrm{G}=$ $0.244731, \mathrm{~T}=0.212548$; substitution rates: $\mathrm{AC}=0.758148, \mathrm{AG}=5.092386, \mathrm{AT}=0.713346, \mathrm{CG}=$ $0.713346, \mathrm{CT}=11.538352, \mathrm{GT}=1.000000$; gamma distribution shape parameter $\alpha=2.403317$. Bootstrap support values for ML greater than or equal to $56 \%$ are given above the nodes. The tree is rooted to Aquasubmersa japonica (KT 2862, KT 2863). The new taxon is shown in bold and blue. 


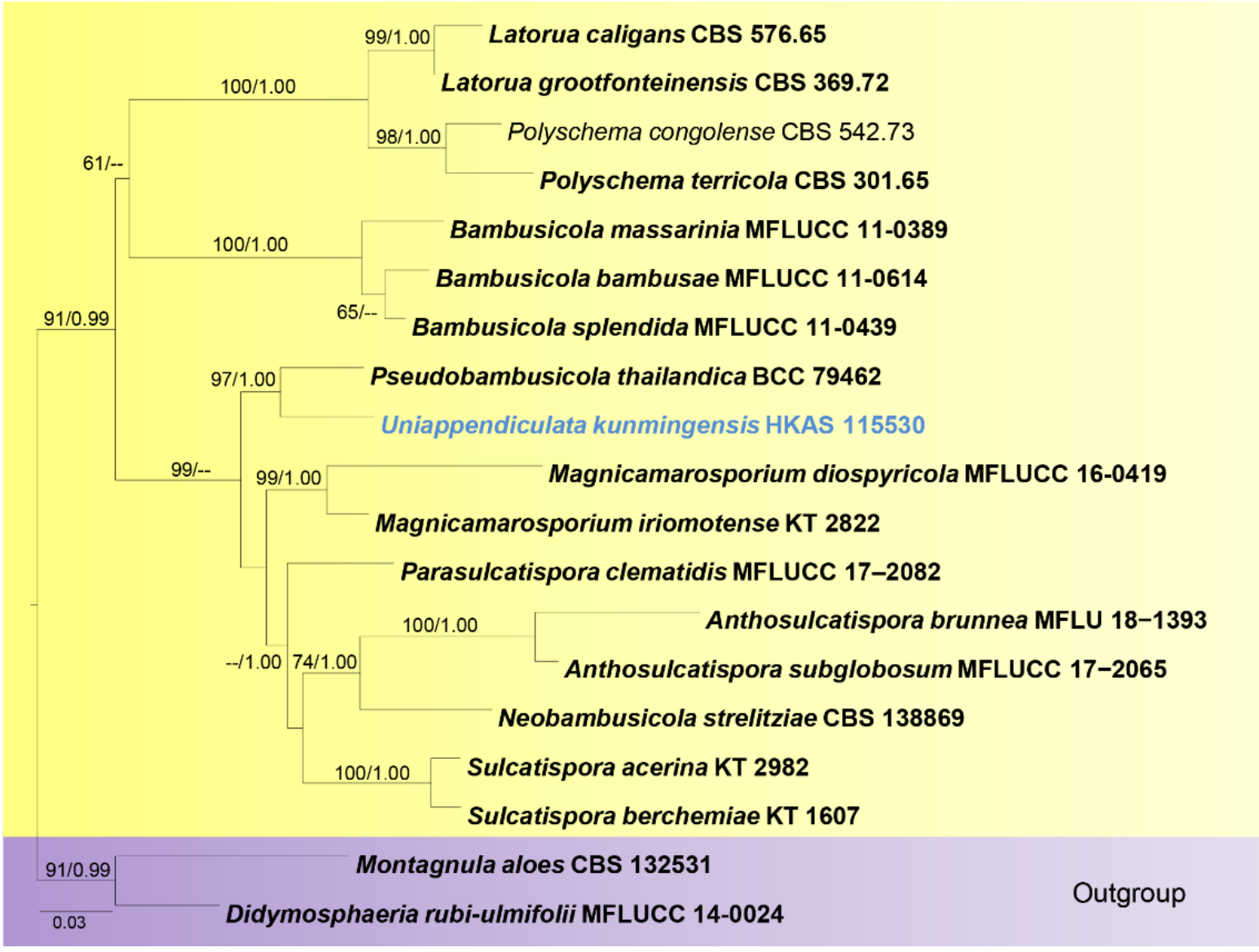

Figure 6 - The best scoring RAxML tree with a final likelihood value of -9124.516643 for combined dataset of LSU, tefl- $\alpha$ and ITS sequence data. The tree is rooted with Montagnula aloes (CBS 132531) and Didymosphaeria rubi-ulmifolii (MFLUCC 14-0024). The matrix had 547 distinct alignment patterns with $24.64 \%$ undetermined characters and gaps. Estimated base frequencies were as follows: $\mathrm{A}=0.228527, \mathrm{C}=0.263570, \mathrm{G}=0.278846, \mathrm{~T}=0.229057$; substitution rates: $\mathrm{AC}=1.094587, \mathrm{AG}=1.973297, \mathrm{AT}=1.123227, \mathrm{CG}=0.720850, \mathrm{CT}=$ $5.866173, \mathrm{GT}=1.000000$; gamma distribution shape parameter $\alpha=0.165842$. The newly generated sequence is in blue. Bootstrap support values for ML equal to or greater than 60\% and BYPP equal to or greater than 0.90 are given above and below the nodes, respectively.

Uniappendiculata kunmingensis Tibpromma, sp. nov.

Fig. 7

Index Fungorum number: IF558616; Facesoffungi number: FoF 10422

Etymology - Named after Kunming, from where the species was first collected.

Holotype - HKAS 115530

Saprobic on dead stem of Acer palmatum. Sexual morph: Undetermined. Asexual morph: Conidiomata acervuli, superficial, solitary, scattered, setae formed on cushions of brown to black, masses of spores all over the dead stem surfaces of the host. Conidiophores 5-20 $\times 1-3 \mu \mathrm{m}(\overline{\mathrm{x}}=$ $16.35 \times 2.14 \mu \mathrm{m}, \mathrm{n}=40$ ), hyaline, simple or septate, branched, smooth-walled. Conidiogenous cells 3-8 $\times 1-3 \mu \mathrm{m}(\overline{\mathrm{x}}=5.35 \times 2.12 \mu \mathrm{m}, \mathrm{n}=40)$, enteroblastic, phialidic, produce only one spore each conidiogenous cells, hyaline, smooth-walled, cylindrical, ellipsoidal, sometimes extending to form new conidiogenous loci (percurrent). Conidia 20-35 $\times 2.5-5 \mu \mathrm{m}(\overline{\mathrm{x}}=13.94 \times 3.85 \mu \mathrm{m}, \mathrm{n}=40$ ), subcylindrical, slightly curved, obtuse at apex, 3-7-septate, sometimes constricted at septum, hyaline, guttulate, thick-walled, with one appendage at each end, 4-10 $\mu \mathrm{m}$ long and without mucilaginous.

Material examined - China, Yunnan Province, Kunming Institute of Botany garden, dead stem of Acer palmatum Thunb. (Sapindaceae), 25 May 2020, S. Tibpromma, ST57 (HKAS 115530, 
holotype).

GenBank numbers - LSU: MZ822227; ITS: MZ822229; tef1- $\alpha$ : MZ889430; RPB2: MZ889431.

Notes - Maximum likelihood analysis using the alignment of LSU, tefl- $\alpha$ and ITS rDNA sequences shows the new isolate as a well-separated lineage from other genera in Sulcatisporaceae with 97\% in ML, 1.00 PP support (Fig. 6). The results from blast searches of the LSU regions of our new isolate matched $98.3 \%$ with Pseudobambusicola thailandica (MG926560), the ITS regions matched 89.71\% with Pseudobambusicola thailandica (MG92655) and the tef1- $\alpha$ regions matched 93.55\% with Sulcatispora acerina (LC014615). We consider our new isolate as a new species based on such significant differences in morphology and molecular data.
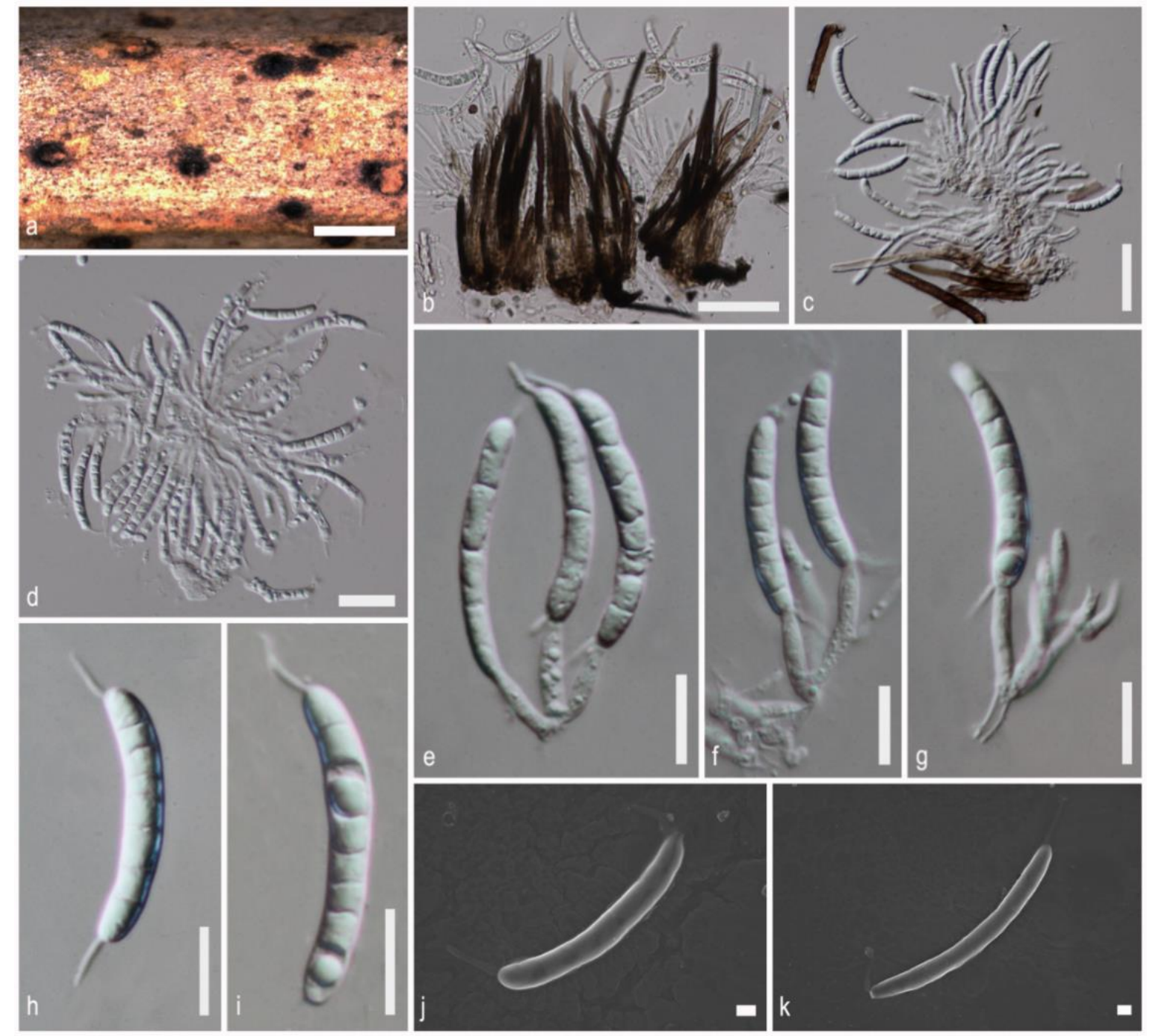

Figure 7 - Uniappendiculata kunmingensis (HKAS 115530, holotype). a Conidiomata on substrate. b Conidiomata with setate. c, d Conidiophore and conidiogenous cell. e-g Developing conidia attach to conidiogenous cells. $\mathrm{h}-\mathrm{k}$ Conidia $(\mathrm{j}, \mathrm{k}$ conidia under a SEM). Scale bars: $\mathrm{a}=1$ $\mathrm{mm}, \mathrm{b}, \mathrm{d}=40 \mu \mathrm{m}, \mathrm{c}=20 \mu \mathrm{m}, \mathrm{e}-\mathrm{i}=10 \mu \mathrm{m}, \mathrm{j}, \mathrm{k}=2 \mu \mathrm{m}$.

\section{Lesser studied habitats}

Hawksworth (2001) stated that some fungal groups had been extensively studied as they affect humans either directly (human pathogens) (e.g. Zalar et al. 2011, Chaturvedi \& de Hoog 2020) or indirectly (plant pathogens, post-harvest colonisers) (e.g. Jayawardena et al. 2019). Moreover, some taxa have been studied as they are easily accessible, especially saprobic taxa in 
temperate regions (e.g. Phukhamsakda et al. 2020, Pem et al. 2021). Hyde et al. (2020) emphasized that some habitats and life modes are overlooked even in extensively studied ecosystems. We agree with this opinion; for example, marine ecosystems have been studied over five decades but mainly focus on a few habitats such as fungi inhabiting mangroves, salt marshes, driftwoods, seaweeds. Jones et al. (2019) stated the importance of focusing on other less studied habitats and life modes such as in deep seawater and hydrothermal vents. Hyde et al. (2020) further list 'Karst fungi, caves, forests (especially pristine rainforests), extreme environments, volcanoes, mountains, deserts, freshwater aquatic systems, lakes, grasslands, indoor environment' as other important but less studied habitats to discover novel taxa. Many asexual genera are still monotypic and regarded as orphaned; we assume this is due to ignoring their original habitats and life modes.

In the last decade, frequent studies of saprobic, pathogenic and endophytic microfungi have revealed numerous new taxa (e.g. Thambugala et al. 2017, Jayawardena et al. 2018). Fungi from the soil, lichenicolous taxa and ectomycorrhizal taxa have also been introduced as novel taxa (Etayo et al. 2020, Guivin et al. 2020, Suija et al. 2020), but in lower numbers. Hence, extensive collections of less studied life modes and habitats may reveal a higher number of unknown species.

Here three habitats are used as examples viz. a. Lichens that produce conidiomata; b. Rock inhabiting taxa; c. Lichenicolous taxa that can be studied to reveal undescribed conidial taxa.

\section{A. Lichens reported with conidiomata}

Lichen-forming fungi (lichenized fungi or lichens) were always the exception to what is now a rule for all fungi, since dual nomenclature was not allowed for sexual and asexual states (Turland et al. 2018). Pycnidia with conidia are common in lichens and known from over half of the described species. The pycnidia are often partly carbonized and the conidia simple, small, acrogenic and hyaline (Smith et al. 2009). Pycnidia and conidia are often uniform within a lichen genus, insomuch that the details are hardly described, however there are exceptions and conidia can be used to separate species within such genera as Bacidina Vězda (Czarnota \& Guzow-Krzemińska 2012) or Strigula Fr. (Aptroot et al. 2008, 2014). Pycnidia typically originate in a rather early developmental state, on the same superficial thallus on which later ascomata are formed. For instance, all species of Astrothelium Eschw., a large genus of tropical lichens, go through a stage with pycnidia. Nonetheless, pycnidia are not reported for most species, because at the time a thallus has pycnidia, it cannot be identified yet to species level (Aptroot \& Lücking 2016).

In the fruticose genus Cladonia P. Browne, pycnidia are almost always present, and apothecia, when present, develop later and often without producing ascospores. Conidia are also not frequently seen, but the diagnostic character within the genus is the colour of the conidial slime, which can be hyaline or reddish, and can vary even between similar species (Ahti 2000). Propagation in this genus is mostly by fragmentation or asexual vegetative diaspores (usually soredia) (Ahti 2000). In the foliose genus Xanthoparmelia (Vain.) Hale (the most speciose lichen genus), pycnidia are formed on the marginal lobes, but only in species that do not form soredia or isidia. Thus, the presence of pycnidia on a small thallus of members of this genus helps in identifying the otherwise sterile specimen, as it can be concluded that it will never form vegetative lichenized diaspores (mostly isidia or soredia), but only apothecia. Given the development of the pycnidia before the apothecia, they have generally been interpreted as spermatia, and probably do not serve for direct propagation. The pycnidial states are not separately named, as this would be illegitimate under the International Code of Nomenclature for algae, fungi, and plants (Turland et al. 2018), but sometimes the pycnidia were thought to be parasitic fungi.

Some lichens have pycnidia with different conidia. Simple, septate and/or curved conidia occur in, e.g. Bacidina, Opegrapha Ach. and Micarea Fr. (e.g. Coppins 1983, Smith et al. 2009, Czarnota \& Guzow-Krzemińska 2012). Brown conidia, so common in free-living asexual taxa, are in lichens only known in Eopyrenula R.C. Harris (Harris 1973, Smith et al. 2009) and Savoronala Ertz et al. (Ertz et al. 2013). Larger conidia are usually called macroconidia, to differentiate from the simple microconidia. They usually occur in addition to microconidia, and in genera such as Anisomeridium (Müll. Arg.) M. Choisy and the afore-mentioned genera, two or sometimes even 
three different conidia can occur in the same species or even on one thallus (Coppins 1983, Smith et al. 2009, Czarnota \& Guzow-Krzemińska 2012, Harris 1995). In lichens, conidia with gelatinous appendages are only known in Strigulaceae. Previously, such thalli were treated in separate fungal nonlichenized genera, Discosiella Syd. \& P. Syd. and Shanoria Anahosur. Those names have been coined as thalli with such pycnidia by mistake as the algae were missed (Lücking 2008). Some Strigula species have very characteristic conidia and are known only in conidial states, viz. $S$. laureriformis Aptroot \& Lücking (Aptroot et al. 2008), S. muriconidiata Aptroot, L.I. Ferraro \& M. Cáceres (Aptroot et al. 2014) and S. pyrenuloides Aptroot (Aptroot et al. 2020). Palmate conidia are known only in Cheiromycina B. Sutton (Printzen 2007, Muggia et al. 2017) and Psammina Sacc. \& M. Rousseau (Earland-Bennett \& Hawksworth 2005, Cáceres \& Aptroot 2016). The most unusual conidia are known in the monotypic genus Savoronala (Ertz et al. 2013). They are produced in sporodochia and their cells are wrapped around a single green algal cell, thus resembling soredia (Ertz et al. 2013).

There are dozens of lichen species that usually, or only occur in a state with pycnidia. The most useful and most used key to those species is presented by Smith et al. (2009). The key treats species belonging to more than 25 unrelated genera occurring in the British Isles but can also be used in other regions with a similar climate.

Sterile lichens with only pycnidia are often left unidentified or even undescribed in case they seem unrecognizable, because it is difficult to assess which genus they might belong to without molecular data. Recently, however, several characteristic species have been recognized and have been assigned to extant or new genera based on sequencing and comparisons with related taxa. Particularly, these are species in the genus Neosergipea M. Cáceres, Ertz \& Aptroot (Aptroot \& Cáceres 2017). Molecular data allowed some conidial species to also be placed within extant genera, that otherwise would have remained undescribed, e.g., Inoderma sorediatum Ertz et al. (Ertz et al. 2018). It is predicted here that more morphologically characteristic sterile lichens with pycnidia will be described as new to science in the forthcoming years, especially from the tropics, with using molecular tools.

Because lichens with conidia do not need to have separate names, only a few generic names have been introduced for conidial lichens. Some of those were described by mistake by authors missing the algae in the thalli, or the absence of ascomatal stages. An example is Sarcinulella Sutton \& Alcorn introduced for Anisomeridium species in which the simple conidia agglutinate into packets. This asexual genus was described without recognizing that it was a lichen and it is now regarded as synonymous with Anisomeridium (Harris 1995). Other examples are the abovementioned Discosiella and sterile specimens of Bacidina species, which have been described as Lichingoldia D. Hawksw. \& Poelt and Woessia D. Hawksw. \& Poelt (Hawksworth \& Poelt 1986, Ekman 1996).

Conidia on lichens can be formed in organs other than pycnidia, sometimes even in structures only known from lichens. These structures can be categorized as sporodochia, hyphophores and campylidia.

Lichen thalli with only sporodochia are rare. They are most commonly found in the genus Tylophoron Nyl. ex Stizenb. (Ertz et al. 2011). The genus Sporodochiolichen Aptroot \& Sipman (Aptroot \& Sipman 2011) has been described to accommodate only sporodochial lichens without other known affinities. The type species has been shown to be a Tylophoron (Ertz et al. 2013), however the remaining three species are still orphaned and waiting to be transferred to other genera. Additionally, Blarneya D. Hawksw., Coppins \& P. James described originally as a sporodochial species is subsumed under Tylophoron (Ertz et al. 2011). Other sporodochial lichens are found in the small genus Cheiromycina (Aptroot \& Schiefelbein 2003, Printzen 2007, Muggia et al. 2017), two lichenized species in the typically lichenicolous-saprotrophic genus Psammina (Earland-Bennett \& Hawksworth 2005, Cáceres \& Aptroot 2016), one species of Micarea (Coppins 1983), Savoronala (Ertz et al. 2013), a species of Eremothecella Syd. (Cáceres et al. 2014), part of Sporodophoron Frisch, Y. Ohmura, Ertz \& G. Thor and Glomerulophoron Frisch, Ertz \& G. Thor (Frisch et al. 2015), Sprucidea penicillata (Aptroot, M. Cáceres, Lücking \& Sparrius) M. Cáceres, 
Aptroot \& Lücking (Cáceres et al. 2017) and a single species within the typically non-lichenized Sclerococcum Fr. (Smith et al. 2009, Diederich et al. 2018).

Hyphophores are most common in foliicolous lichens and display a huge variation of shapes, from threads with hanging conidia to umbrella- or shortly stalked shell-shaped structures with conidia forming underneath. The families Asterothyriaceae and Gomphillaceae are particularly rich in variously shaped hyphophores. Species without known ascomata have not been described, or at least none have been accepted to date. Batista and co-workers described several species in the last century, but this was usually based on incomplete information, as algae were usually not observed. Lücking et al. (1998) presented an evaluation of these taxa. Even though the genera described by Batista \& Maria (1965) are not currently accepted, they should be kept in mind when genera are being delineated again, as is commonly being done now. Keys and descriptions to lichens with hyphophores can be found in e.g. Ferraro (2004), Kalb \& Vězda (1988), Lücking (2008), and Lücking et al. (2006).

Campylidia are three-dimensional structures with conidia, occurring in Calopadia Vězda and related genera. They are triangular to ear-shaped, sometimes with fringes. Their function is to facilitate the dispersal of conidia, as it catches rain droplets and the conidia disperse with the water. Malme (1935) was the first to understand the function. Later, many authors, notably Santesson (1952), got it wrong and interpreted the conidia as parasitic fungi, accepting the genus name Pyrenotrichum Mont. for them. Sérusiaux (1986) showed the nature of the campylidia again, and Aptroot \& Sipman (1993) found these structures in a totally unrelated group of lichens, viz. Musaespora Aptroot \& Sipman.

Apparently, many asexually reproducing species can be revealed in lichens. It is necessary to explore this in geographic areas that have not been studied systematically (e.g. biodiversity rich, tropical regions) as previously discussed.

Caprettia Bat. \& H. Maia, Atas Inst. Micol. Univ. Pernambuco 2: 377 (1965)

The genus Caprettia was introduced by Batista \& Silva-Maia (1965) with C. amazonensis Bat. \& H. Maia as the type species. Subsequent studies by Sérusiaux \& Lücking (2003), Lücking (2008) and Yeshitela et al. (2009) introduced six taxa from Costa Rica, Ethiopia, and Papua New Guinea. Currently, all the species lack DNA sequences, thus identification is based on only morphology. Herein, we introduce a new lichen species, Caprettia lichexanthotricha, from Brazil.

We assume that the species of Caprettia are mainly restricted to Central and South America and in some countries of Africa. Our new collection indicates hidden diversity in Brazil, which has enormous fungal diversity. However, tropical countries or regions which have not been thoroughly studied (e.g. Western Ghats in India, coastal regions of Madagascar) could also harbour more novel taxa.

Caprettia lichexanthotricha Aptroot \& M.F. Souza sp. nov.

Fig. 8

Index Fungorum number: IF 551453; Facesoffungi number: FoF 10423

Etymology - From lichexanthone and tricha (hair).

Holotype - CGMS 82022

Thallus pale greenish grey, dull, almost dusty, thin, covering an area of up to $10 \mathrm{~cm}$ diam., without prothallus. Algae trentepohlioid, green, c. 10-17 $\times 7-12 \mu \mathrm{m}$, partly escaping from the thallus and becoming filamentous. Sexual morph: Undetermined. Asexual morph: Conidiomata pycnidial, densely covering the thallus, superficial, tubular, not tapering, with a dull black, partly (especially often at the tips) white pruinose, often branched, hair-like beak of c. $0.3-0.5 \times 0.1 \mathrm{~mm}$. Conidiophores hyaline, c. $1 \mu \mathrm{m}$ wide. Conidia hyaline, bacillar, c. 4-4.5 $\times 1.5 \mu \mathrm{m}$, mostly agglutinated together in gelatinous masses with c. 100 conidia.

Chemistry - Thallus patchily UV+ yellow, with lichexanthone.

Material examined - Brazil, Paraná, Guaraqueçaba, Tagaçaba, $10 \mathrm{~m}$ alt., on tree bark, October 2020, A. Aptroot \& M.F. Souza (82022, CGMS, holotype). 
Notes - Caprettia is a small genus in the Monoblastiaceae Walt. Watson (Hongsanan et al. 2020). So far eight species are known, all exclusively from South America. Most of the species are foliicolous and have a very inconspicuous thallus. The new species is the first with lichexanthone and the first reported with secondary metabolites.
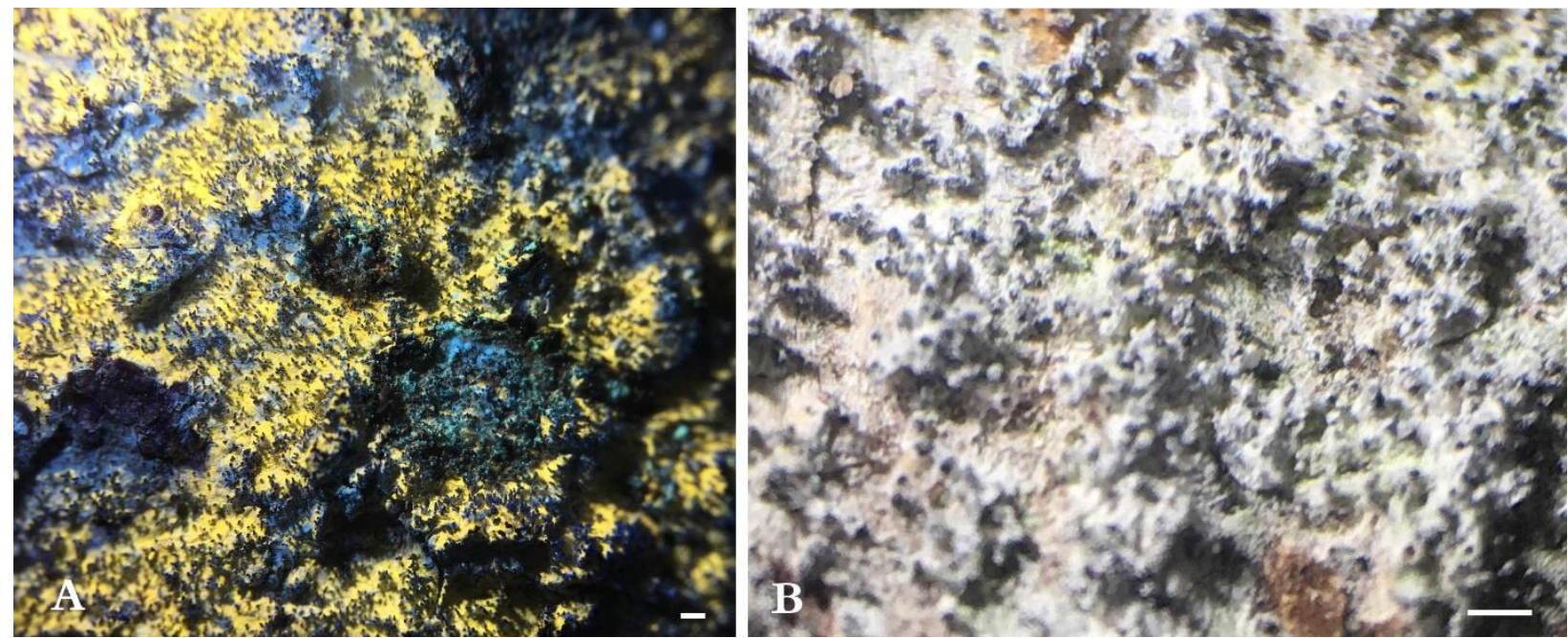

Figure 8 - Caprettia lichexanthotricha (CGMS 82022, holotype). A Thallus under 365nm UV light. B Thallus under normal light.

\section{B. Lichenicolous taxa}

Lichenicolous taxa (lichenicolous fungi or lichenicolous lichens) are exclusively parasitic on lichens and over 2,350 species have been described (Diederich et al. 2018). Hawksworth (1991) predicted that the diversity of lichenicolous taxa has been overlooked, and this prediction was confirmed in Hawksworth \& Lücking (2017) who provided statistics for newly described species from the mid-1970s to the present. However, most of the known lichenicolous taxa have been reported from temperate regions, thus the species diversity of these fungi in tropical regions is unclear. Although, during the last decade, a large number of lichen species have been described across tropical and sub-tropical regions, the surveys on lichenicolous fungi have been carried out with less intensity, and only in selected countries, among others, in Bolivia, Colombia, Costa Rica, Ecuador, Kenya, New Guinea or USA (Florida) (e.g. Matzer 1996, Diederich 1997, Etayo 2002, 2017, Etayo et al. 2015, Suija et al. 2018, Diederich et al. 2019, Flakus et al. 2019 a, b). Boonmee et al. (2017) revised old genera which were reported as lichenicolous (e.g. Myxophora amerospora Döbbeler \& Poelt and Opegrapha reactiva (Alstrup \& D. Hawksw.) Etayo \& Diederich) and further discussed about the necessity of future studies to reveal the hidden taxa. Thus, a higher number of undiscovered, lichenicolous species could be reported in the future in tropical countries that have high lichen diversity (Diederich 1997, Flakus et al. 2016).

Lichenoconium Petr. \& Syd., Beih. Reprium nov. Spec. Regni veg. 42(1): 432 (1927) [1926]

The genus Lichenoconium was introduced by Petrak \& Sydow (1927) with L. lichenicola (P. Karst.) Petr. \& Syd. as the type species. Twenty-seven epithets are listed in Index Fungorum (2021) but only 20 species are accepted in Species Fungorum (2021). Nevertheless, Diederich et al. (2018) accepted only 15 species. Since Petrak \& Sydow (1927), several studies revisited the genus which indicated the members of Lichenoconium show widespread distribution (e.g. Alstrup \& Cole 1998, Cole \& Hawksworth 2004, Lawrey et al. 2011). During the present study, a new Lichenoconium taxon was isolated growing on the thallus of Heterodermia comosa from Bolivia, which is herein presented as the new lichenicolous species L. hawksworthii. As far as we know L. cargillianum (Linds.) D. Hawksw. (from Bolivia, Chile, Ecuador fide Etayo \& Sancho 2008, Flakus \& Kukwa 2012, Etayo 2017), L. echinosporum D. Hawksw. (from Ecuador fide Etayo 2017), L. erodens M.S. 
Christ. \& D. Hawksw. (from Chile, Ecuador fide Etayo \& Sancho 2008, Etayo 2017), L. lecanorae (Jaap) D. Hawksw. (from Bolivia, Chile fide Diederich 2003, Etayo \& Sancho 2008), L. lichenicola (P. Karst.) Petr. \& Syd. (from Chile fide Etayo \& Sancho 2008), L. usneae (Anzi) D. Hawksw. (from Chile, Colombia, Ecuador fide Etayo 2002, 2017, Etayo \& Sancho 2008) and L. xanthoriae M.S. Christ. (from Colombia) have been reported from South America. We assume that there could be a large number of asexual species to be described from tropical South American countries, such as Bolivia and Brazil.

Lichenoconium hawksworthii Flakus, Etayo, Kukwa \& Rodr. Flakus, sp. nov.

Fig. 9 MycoBank number: MB838684; Facesoffungi number: FoF 10424

Holotype - KRAM-L 72092

Etymology - The new species is named in honour of Professor David L. Hawksworth, eminent British mycologist and lichenologist, for his great contribution to our knowledge of lichenicolous asexual taxa and to the Lichenoconium genus.

Mycelium indistinct, completely immersed in the host, composed of hyaline to pale brown hyphae, septate, uneven in thickness, about 2-3 $\mu \mathrm{m}$ thick. Sexual morph: Undetermined. Asexual morph: Conidiomata pycnidial, arising singly or in groups, at maturity the uppermost part evidently exposed, convex, black and matt, subglobose to obpyriform, (150-) 200-250 $\mu \mathrm{m}$ high, (70-)150200(-230) $\mu \mathrm{m}$ wide, ostiole conspicuous, apical, covered by accumulating, dark-brown conidial mass. Conidiomatal wall pseudoparenchymatous composed of 3-6 layers of cells, 8-25 $\mu \mathrm{m}$ thick, with cells irregularly polyhedral to almost subglobose in shape, lumen $3-10 \times 2-4 \mu \mathrm{m}$. Wall thickened in the upper part, pale to dark brown below and dark purple in the upper and lateral part, apical part usually incrusted by hyaline crystals, the purple pigment located in the exciple becoming strongly aeruginose in $\mathrm{KOH}$. Conidiogenous cells forming a single layer lining the pycnidial cavity, subcylindrical, phialidic, with visibly narrower necks, hyaline, (6-)9-12 × (22.5-3.5 $\mu \mathrm{m}$. Conidia arising from the apices of the conidiogenous cells, abundant, accumulating in a dry mass in the conidiomatal cavity, globose to subglobose or rarely slightly obovoid, not attenuated, apically rounded, basally sometimes narrower, the base usually truncated, yellow-brown to dark-brown, almost black in mass, delicately warted, aseptate, $(3-) 3.5-4(-4.5) \times(2.5) 3-3.5(-4)$ $\mu \mathrm{m}$.

Material examined - Bolivia, Dept. Tarija, Prov. Burnet O'Connor, close to Entre Ríos, new road between Tarija and Entre Ríos, 21³0'47'S, 64'11'49”W, $1338 \mathrm{~m}$, disturbed TucumanoBoliviano forest with shrubs and Tillandsia, on thallus of Heterodermia comosa, 28 July 2015, A. Flakus 27364 (KRAM-L 72092, holotype, LPB - isotype). GenBank No.: MW315198

Additional specimens examined - Lichenoconium cf. cargillanum: Bolivia, Dept. Tarija, 22 $02^{\prime} 38^{\prime \prime} \mathrm{S}, 64^{\circ} 35^{\prime} 47^{\prime \prime} \mathrm{W}$, on apothecial disc of Punctelia sp., 2015, A. Flakus 27023 (KRAM, LPB); GenBank No.: MW315196; Lichenoconium erodens: Bolivia, Dept. Chuquisaca, $18^{\circ} 45^{\prime} 53^{\prime}$ 'S $64^{\circ} 49^{\prime} 57^{\prime \prime} \mathrm{W}$, on thallus of Parmotrema reticulatum, 2015, A. Flakus 26452 (KRAM, LPB); GenBank No.: MW315197.

Ecology and distribution - Lichenoconium hawksworthii is known from the type locality in Tucumano-Boliviano forests in Bolivian Andes and grows on epiphytic Heterodermia comosa.

Notes - The phylogenetic placement of Lichenoconium in Dothideomycetes was shown by Lawrey et al. (2011). Ertz \& Diederich (2015) recently found that Lichenoconium is closely related to Abrothallus, however, to fully understand the phylogenetic relationship between those two genera additional analyses with larger datasets are necessary.

The new species occurs on discolored or brownish infected parts of the host thalli, and is characterized by only partly immersed, large conidiomata $(150-250 \times 70-230 \mu \mathrm{m})$, large conidiogenous cells, small conidia $(3-4.5 \times 2.5-4 \mu \mathrm{m})$ and the presence of purple pigment in apical and lateral part of exciple becoming strongly aeruginose in $\mathrm{KOH}$. The two most morphologically similar species are Lichenoconium aeruginosum and L. pyxidatae growing mainly on Cladonia. Lichenoconium aeruginosum differs in smaller conidiomata, 80-100(-140) $\mu \mathrm{m}$ diam., with bluish pigment (turning aeruginose in $\mathrm{KOH})$, and larger conidia, $(3.4-) 3.8-4.6(-5.4) \times(3.0-) 3.4-3.8(-$ 
4.3) $\mu \mathrm{m}$. Lichenoconium pyxidatae also differs in smaller conidiomata, (60-) $120(-150) \mu \mathrm{m}$ diam., with brown pigment in exciple (becoming darker and olivaceous in $\mathrm{KOH}$ ), and slightly smaller conidia, (2-)2.5-3.5(-4) × 2-3 $\mu \mathrm{m}$ (Hawksworth 1977, Cole \& Hawksworth 2004, Lawrey et al. 2011).

Our phylogenetic analyses based on nuLSU sequences (Fig. 10) show that L. hawksworthii is placed in a highly supported clade that includes six species of Lichenoconium. Although we included all Lichenoconium sequences available in GenBank in our analyses, the relationship of our new species to other species within the genus remains uncertain due to the lack of statistical support. However, it seems to place together with the Bolivian sample of $L$. cf. cargillanum (growing on apothecial discs of Punctelia). The significant phylogenetic distance between $L$. hawksworthii and L. aeruginosum together with morphological discrepancies and different host preferences seems to justify the description of the new species.
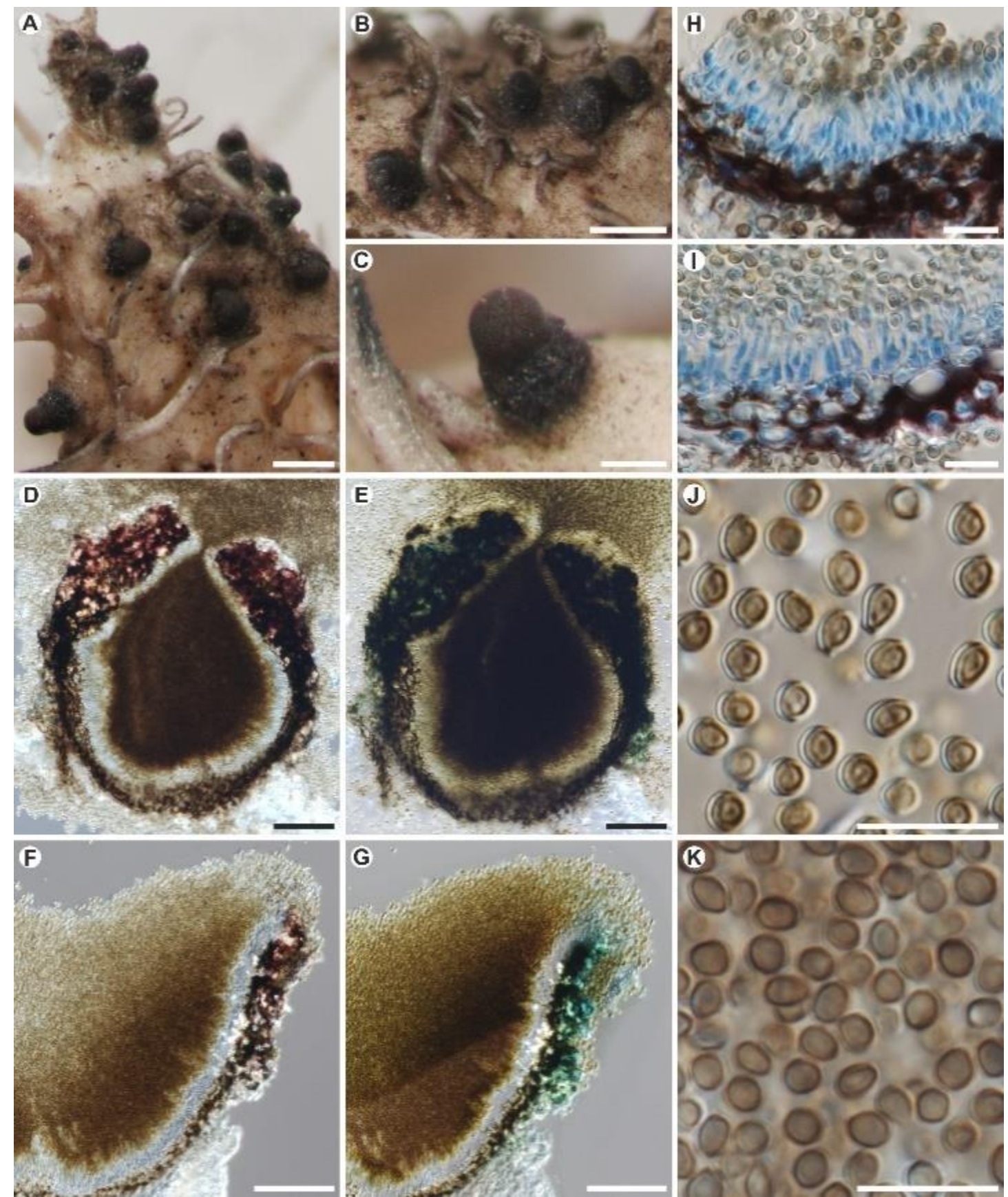

Figure 9 - Lichenoconium hawksworthii (KRAM-L 72092, holotype). A-C Habit of conidiomata growing in thallus of Heterodermia comosa. D-E Transversal section of conidiomata showing 
excipular pigmentation and conidial mass filling the conidiomatal cavity ( $\mathrm{D}$ in water, $\mathrm{E}$ in $\mathrm{KOH}$ ). $\mathrm{F}-\mathrm{G}$ Transversal section of exciple ( $\mathrm{F}$ in water, $\mathrm{G}$ in $\mathrm{KOH}$ ). $\mathrm{H}-\mathrm{I}$ Conidiogenous cells (in LPCB). $\mathrm{J}-\mathrm{K}$ Conidia ( $\mathrm{J}$ in water, $\mathrm{K}$ in LPCB). Scales: A-B $=250 \mu \mathrm{m}, \mathrm{C}=100 \mu \mathrm{m}, \mathrm{D}-\mathrm{E}=50 \mu \mathrm{m}, \mathrm{F}-\mathrm{K}=$ $10 \mu \mathrm{m}$.

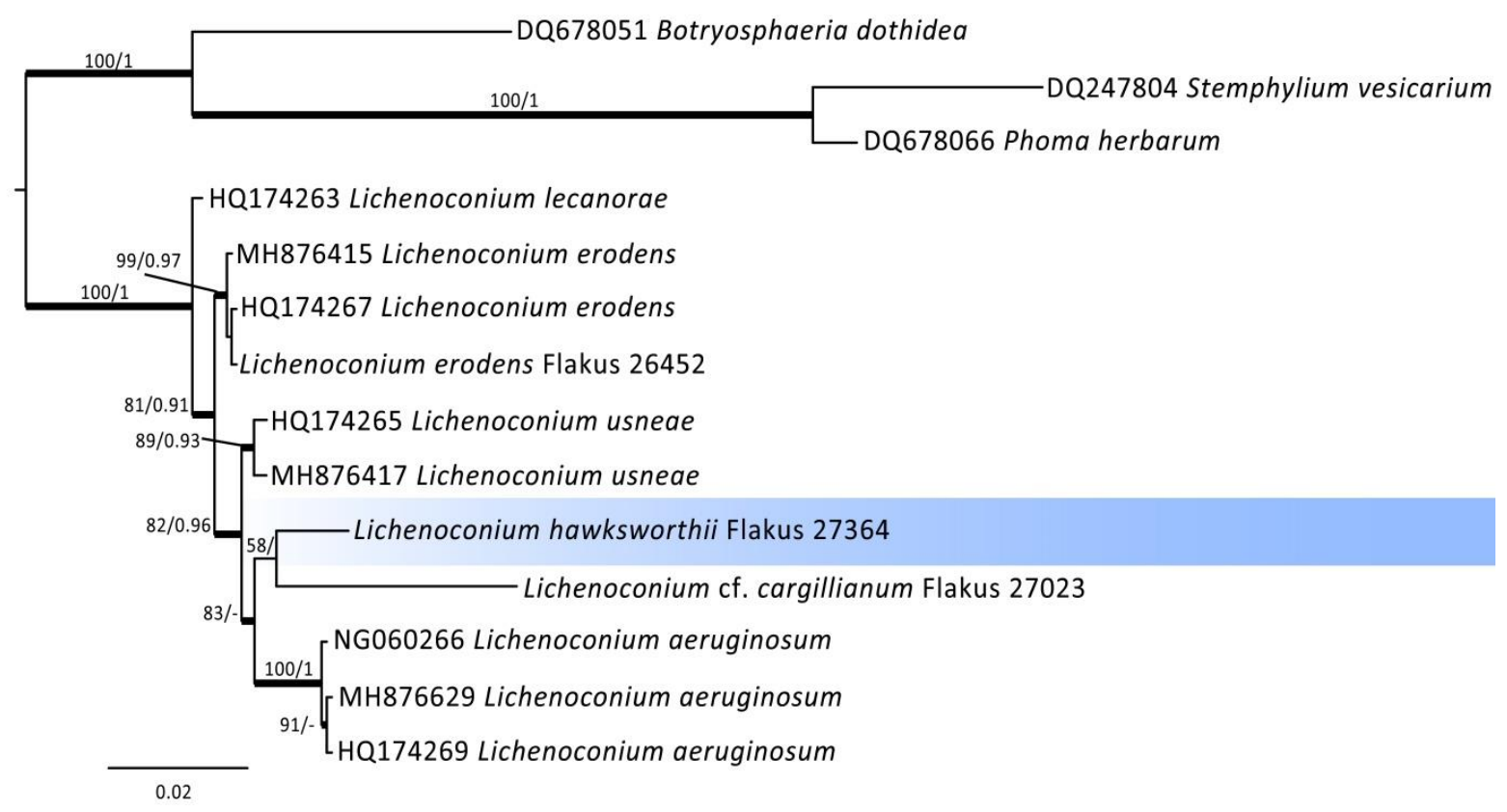

Figure 10 - Phylogenetic reconstruction of the systematic position of Lichenoconium hawksworthii within Lichenoconium inferred from ML analyses of nuLSU rDNA dataset. The outgroup is represented by Botryosphaeria dothidea, Phoma herbarum and Stemphylium vesicarium. Bold branches represent either bootstrap values $\geq 70$ and/or Bayesian posterior probabilities $\geq 0.95$.

\section{Rock inhabiting fungi (RIF)}

Fungi found on rocks can be separated into two ecologically and taxonomically different groups: (i) hyphomycetes of soil and epiphytic origin (Sterflinger \& Prillinger 2001) and (ii) black (highly melanized) fungi that are slow growing, typically with meristematic development, (i.e. Ascomycota, mainly within orders Capnodiales and Dothideales in Dothideomycetes and Chaetothyriales in Eurotiomycetes) that form peculiar and compact microcolonies (Wollenzien et al. 1997, Quan et al. 2020) (Fig. 11).

Rock-inhabiting hyphomycetes, proliferating during milder and humid seasons, such as Aureobasidium pullulans or hormonema-like fungi reported on marble artworks in Sicily, have been described as coming from surrounding vegetation (leaves, barks or soils) (De Leo et al. 1996). Phoma species have frequently been isolated from rock surfaces in humid as well as in semi-arid areas (Sterflinger \& Prillinger 2001), and also reported together with Epicoccum species from surfaces of monuments in Vienna and from the historical quarry in a rural area near there (Sterflinger et al. 1999, Sterflinger \& Prillinger 2001). The presence of these hyphomycetes on monument surfaces has a considerable impact on monument alteration, causing evident surface discoloration (Diakumaku et al. 1995).

Black meristematic fungi prevail under harsh and hostile conditions where they are not outcompeted by fast growing fungi (Selbmann et al. 2005). They are variously named as black yeasts, meristematic, microcolonial or rock-inhabiting fungi (RIF), to evoke the idea of organisms perfectly adapted to life on rocks and are among the most competent colonizers of this substratum, providing exceptional occasions for species diversification. In fact, it is now clear that rocks worldwide serve as enduring reservoirs of new RIF species, which are consistently encountered as soon as a new stone surface is sampled and studied (Ruibal et al. 2005, 2009, Selbmann et al. 2005, 2008) (Fig. 12). 


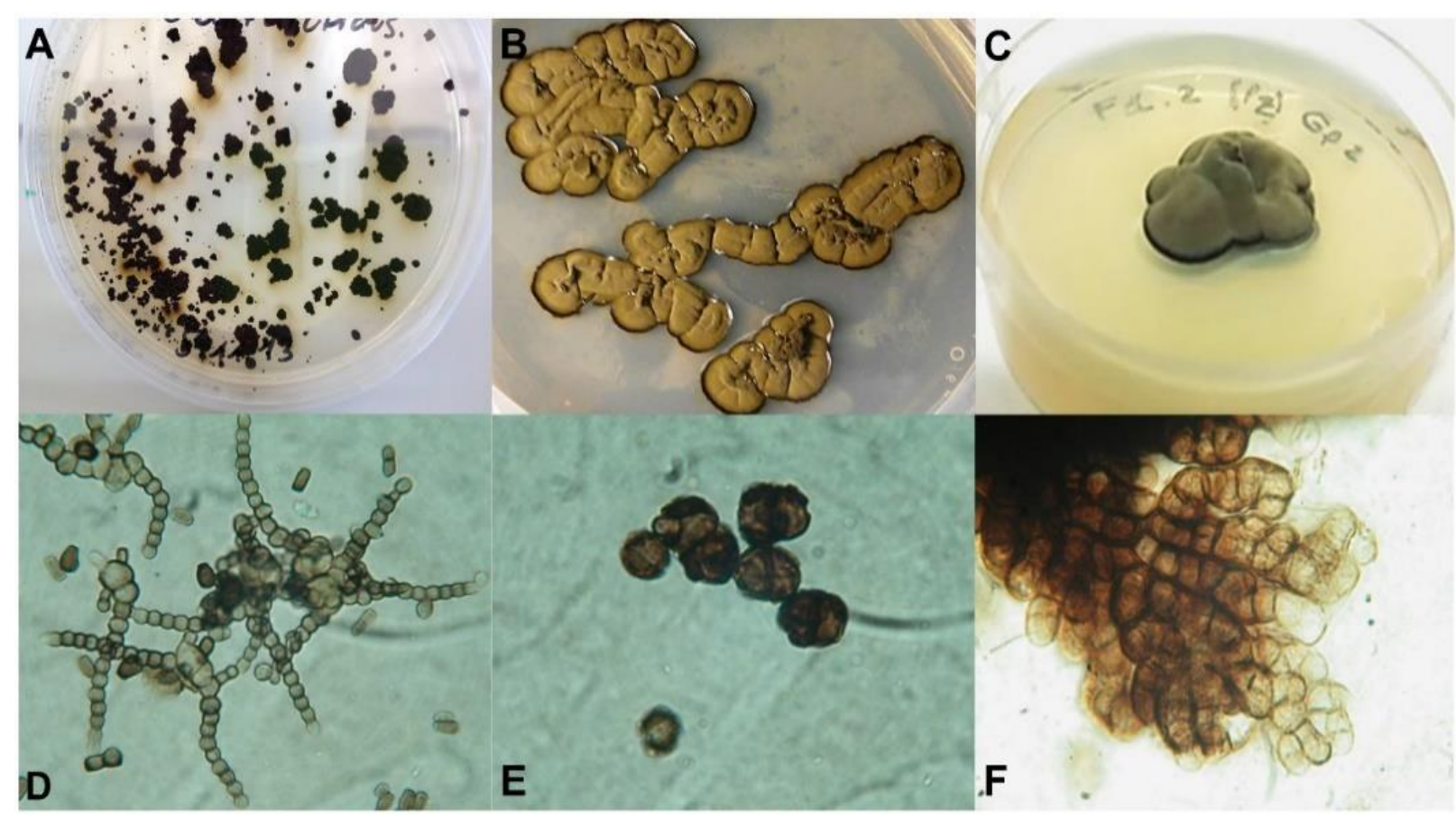

Figure 11 - Examples of black fungi. A Cryomyces antarcticus. B Rachicladosporium antarcticum. C Extremus antarcticus. D Saxomyces alpinus. E Cryomyces minteri.

\section{F Rachicladosporium mcmurdoi.}

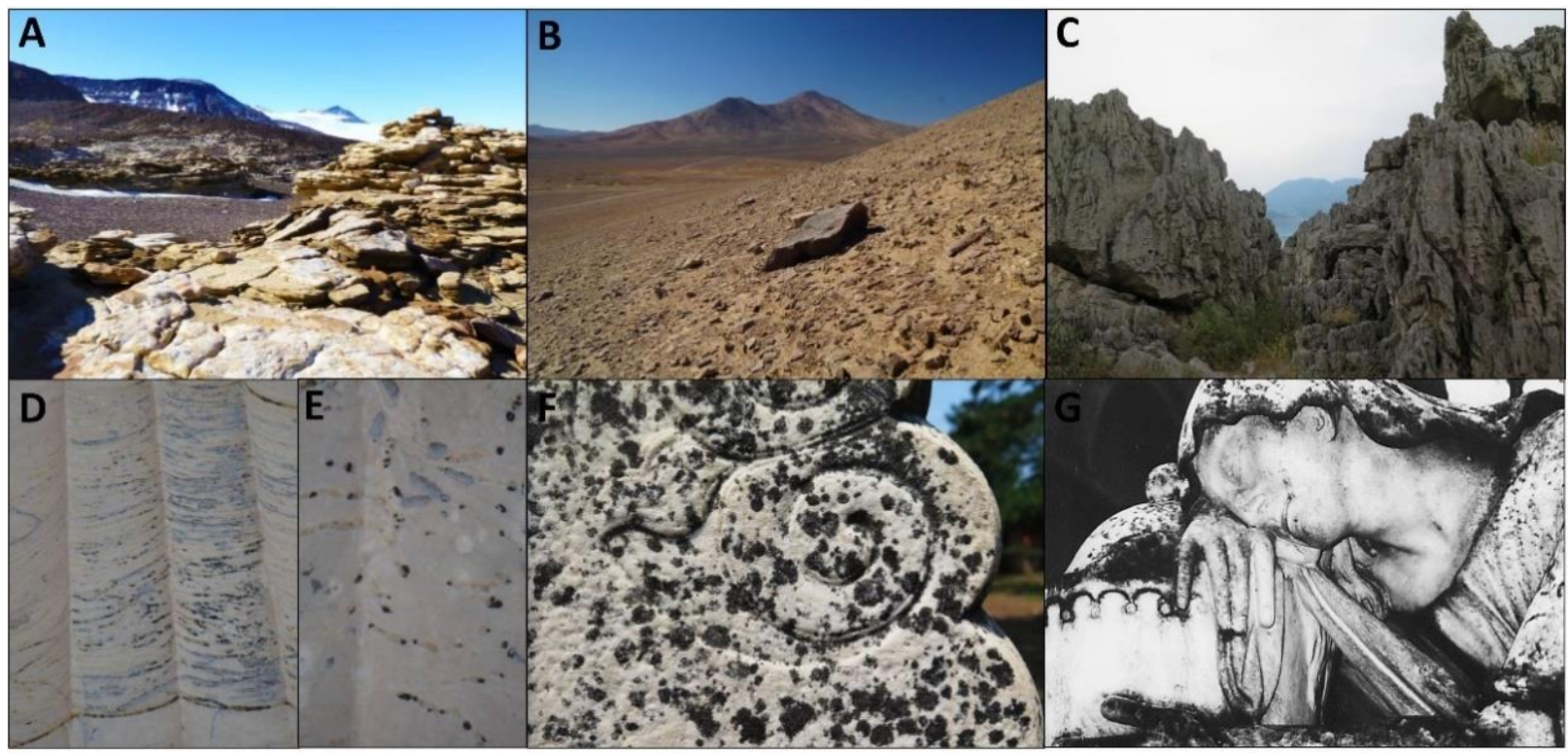

Figure 12 - Examples of natural rocks where black meristematic fungi are found: A Battleship Promontory, McMurdo Dry Valleys, Southern Victoria Land, Antarctica (Photo credit: Italian National Program for Antarctic Researches). B Atacama Desert, Chile. C The Karst landform area in Guizhou province (Sun et al. 2020). D, E Temple of Hephaestus in Athens, Greece. F Monument in Beijing, China (Sun et al. 2020). G Black biofilms on the horizontal parts of the Khitrovo tombstone, 18th century necropolis, the Alexander Nevsky Abbey, Saint Petersburg, Russia.

RIF are invariably asexual morphs. They were overlooked for a long time in routine studies due to their very slow growth rate and poor competitive abilities. Often, they are even confused with ash, soot or dust on building and monument surfaces. With improvements in isolation procedures, it has become clear that they are much more common and widespread than previously believed. Yet, their sparse morphology, morphological plasticity, and scarce metabolic 
competences has hampered identification, and it is impossible to use only morphology to support species identification and description. Indeed, the high degree of rock-inhabiting species biodiversity only became apparent when molecular techniques became routine in fungal systematics.

Taxonomically, RIF belong to lineages of Dothideomycetes, Eurotiomycetes (specifically in the order Chaetothyriales) (Ruibal et al. 2009, Egidi et al. 2014, Su et al. 2015), and Arthoniomycetes (Muggia et al. 2021). In Dothideomycetes, rock-inhabiting species belong mainly to the order Capnodiales, but a few lineages are also found in Pleosporales, Dothideales and Myriangiales. However, some clusters are still unclassified at the order level.

Notably, some rock-inhabiting species show a worldwide distribution, while others seem to occur in specific restricted areas. For instance, the black fungal species Elasticomyces elasticus and Recurvomyces mirabilis have been reported from Antarctica, the Andes and the Himalaya, and from Antarctica and the Alps, respectively. On the other hand, most species show a more restricted distribution and occur in specific areas; for instance, Bradymyces alpinus has been recorded only from Alpine rocks at high altitude and B. yunannensis only from rocks in China. Lithohypha guttulata occurs in the Mediterranean area and L. catenulata from Tibet. The species Knufia petricola, K. marmoricola, $K$. karalitana, $K$. vaticanii, $K$. perforans occur in the Mediterranean area, while $K$. separata and $K$. calcareola are from limestone in Beijing and from sandstone in Yunnan province (China), respectively. Cryomyces antarcticus and C. minteri were found exclusively in the Antarctic desert, while C. funiculosus and $C$. montanus are only retrieved on rocks above 3,000 meters in the Alps. In some cases, this limited distribution encompasses the whole genus, as for Friedmanniomyces (Antarctica), Monticola (Alps), Perusta (Spain), Saxomyces (Alps), and Spissiomyces, Rupestriomyces and Anthracina (China).

Studies on Antarctic ice-free areas revealed a new RIF species in the genus Rachicladosporium based on morpho-molecular analyses (Figs 13, 14). Thus, it is herein introduced as Rachicladosporium aridum sp. nov.

Rachicladosporium Crous, U. Braun \& C.F. Hill, Stud. Mycol. 58: 38 (2007)

The genus Rachicladosporium was introduced by Crous et al. (2007) with $R$. luculiae as the type species. Most of the species have been reported from both rocks or plant materials. Members of Rachicladosporium have been reported as species associated with leaf spots (e.g. R. luculiae fide Crous et al. 2007), as saprobes (e.g. $R$. americanum Cheew. \& Crous fide Cheewangkoon et al. 2009, R. iridis (Auersw.) Crous fide Crous et al. 2020), and as RIF species (e.g. R. antarcticum Egidi \& Onofri fide Egidi et al. 2014).

It is plausible that there could be a large number of species to be discovered from different localities as different life modes.

Rachicladosporium aridum Selbmann \& Coleine, sp. nov.

Fig. 13

MycoBank number: MB 839200; Facesoffungi number: FoF 10416

Holotype - MUT6494

Etymology - named after the extremely dry conditions of the natural environment of the fungus (McMurdo Dry Valleys).

Description based on 12 -week-old cultures grown on malt extract agar (MEA) at $15^{\circ} \mathrm{C}$. Slow growing colonies attaining up to $15 \mathrm{~mm}$ in diam. in 12 weeks, black in surface and reverse, compact, cerebriform, lobed with irregular margin crusty and hard, brittle in texture. Hyphae dark brown, septate, thick-walled, with apical or lateral germination producing elongated, cylindrical, regular hyphae 2.5-3 $\mu \mathrm{m}$ wide; torulose hyphae often present, composed of swollen cells, 4.4-5.5 $\mu \mathrm{m}$ wide, with or without transverse septa, brown, thick-walled, smooth, easily evolving in meristematic growth. Torulose hyphae showing polar growth by enteroblastic proliferation and branching by laterally enteroblastic elongation in acropetal chains, liberating by arthric secession, 3.5-4.5 $\mu \mathrm{m}$ long scared ramoconidia with truncated ends. Sexual morph: Undetermined. Asexual morph: Conidiophores micronematous 5.5-7.5 $\mu \mathrm{m}$ wide. Conidiogenous cells (hyphae) holothallic, 
integrated or discrete, determinate. Conidial secession schizolytic. Conidia globose, doliiform, brown to dark brown, 0-3-septate, very thick walled, coated with fragmented incrustations, 5.5-7.5 $\mu \mathrm{m}$ wide, forming by thallic-arthric disarticulation of the apical and lateral branches of the conidiogenous hyphae. Terminal or intercalary chlamydospore-like cells sometimes present.

Material examined - Antarctica, Mt. Elektra, McMurdo Dry Valleys, collected by Laura Selbmann, MUT6494, holotype = MNA-CCFEE 6514, Culture preserved at $-150^{\circ} \mathrm{C}$ and in dried condition.

GenBank accession numbers - Rachicladosporium aridum MNA-CCFEE 6514T (ITS, MW834577) and Rachicladosporium aridum MNA-CCFEE 6480 (ITS, MW834584; rpb2, 2446081).

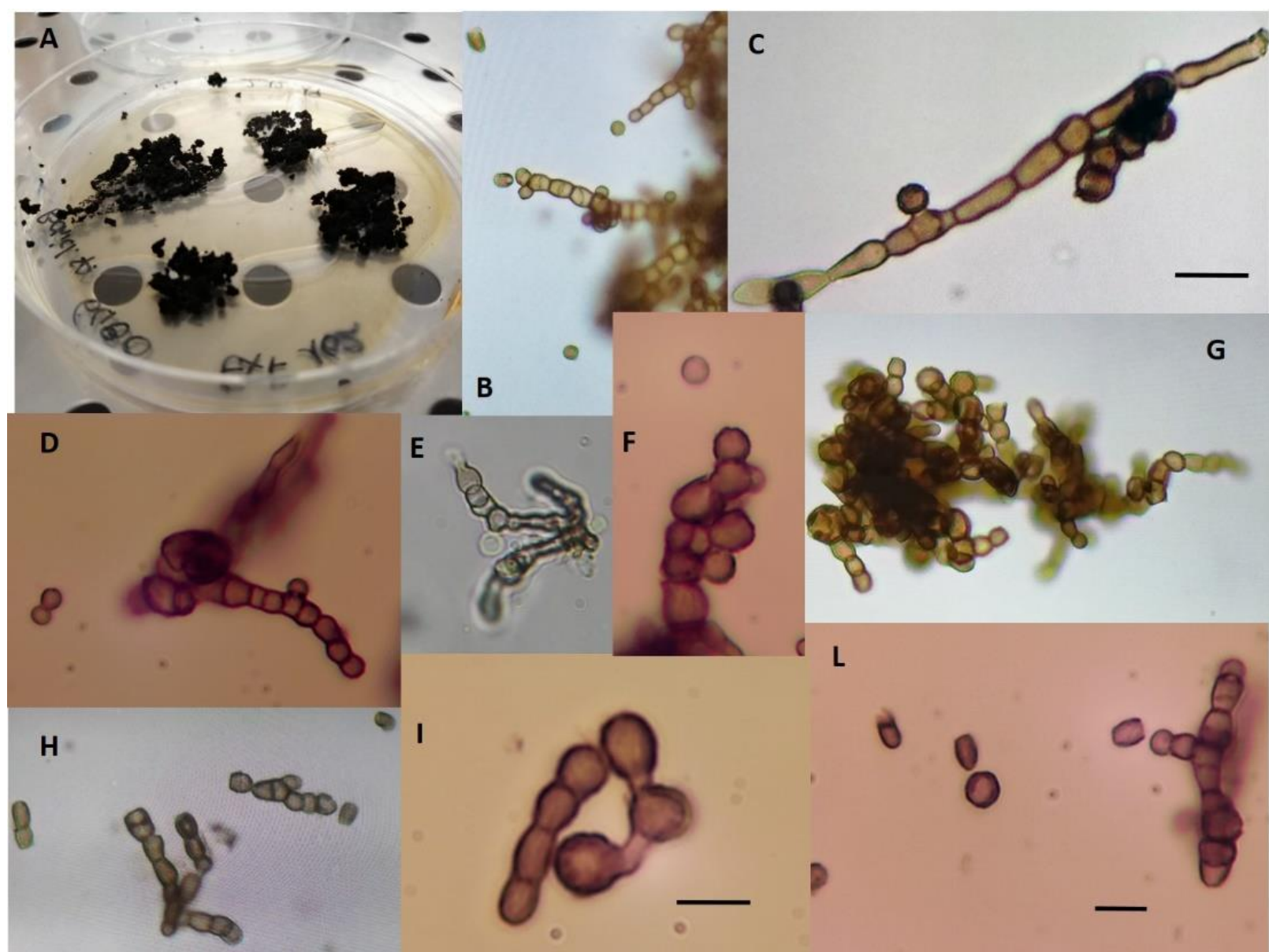

Figure 13 - Rachicladosporium aridum (MNA-CCFEE 6514, holotype). A colony appearance. B, D, L Torulose hyphae with 1- and 2-septate swollen cells. F, G Meristematic growth. E, L Arthric conidiation. H 2-3 scarred ramoconidia. I Terminal and intercalary chlamydospores. $\mathrm{G}$ Thick cell walled conidium with encrustations. Enteroblastic proliferation. C, D, E Micronematous conidiophores with thick cell walled conidium. Scale bars $=10 \mu \mathrm{m}$.

\section{Fungi-rich, geographically widespread hosts (and their families) and less studied hosts (e.g. endemic plants)}

Collecting fungi based on the host is one of the popular methods in mycology, thus most of the studies provide host-fungi indices in their publications (e.g. Ellis 1971, Sutton 1980, Nag Raj 1993). Farr \& Rossman (2021) is continuously updating, host-fungi index, which is one of the important resources in current mycology. In traditional, morphological based mycology, the identification and naming of fungi was based on the host (Jayawardena et al. 2019). Hence, giving two names for one taxon is common, but DNA sequence-based studies suggested to regard these morphologically-defined species as synonyms of other species (Phillips et al. 2013, Groenewald et 
al. 2013). Nevertheless, DNA sequence-based phylogenetic studies reveal cryptic species that show overlapping morphological characters but inhabit the same host or different hosts (Bensch et al. 2015). Besides, studies that used polyphasic approaches (Maharachchikumbura et al. 2021) reveal hundreds of novel taxa even from extensively studied localities and hosts in the last decade (e.g. Wijayawardene et al. 2016, Wanasinghe et al. 2018a, Hyde et al. 2019, Li et al. 2020).

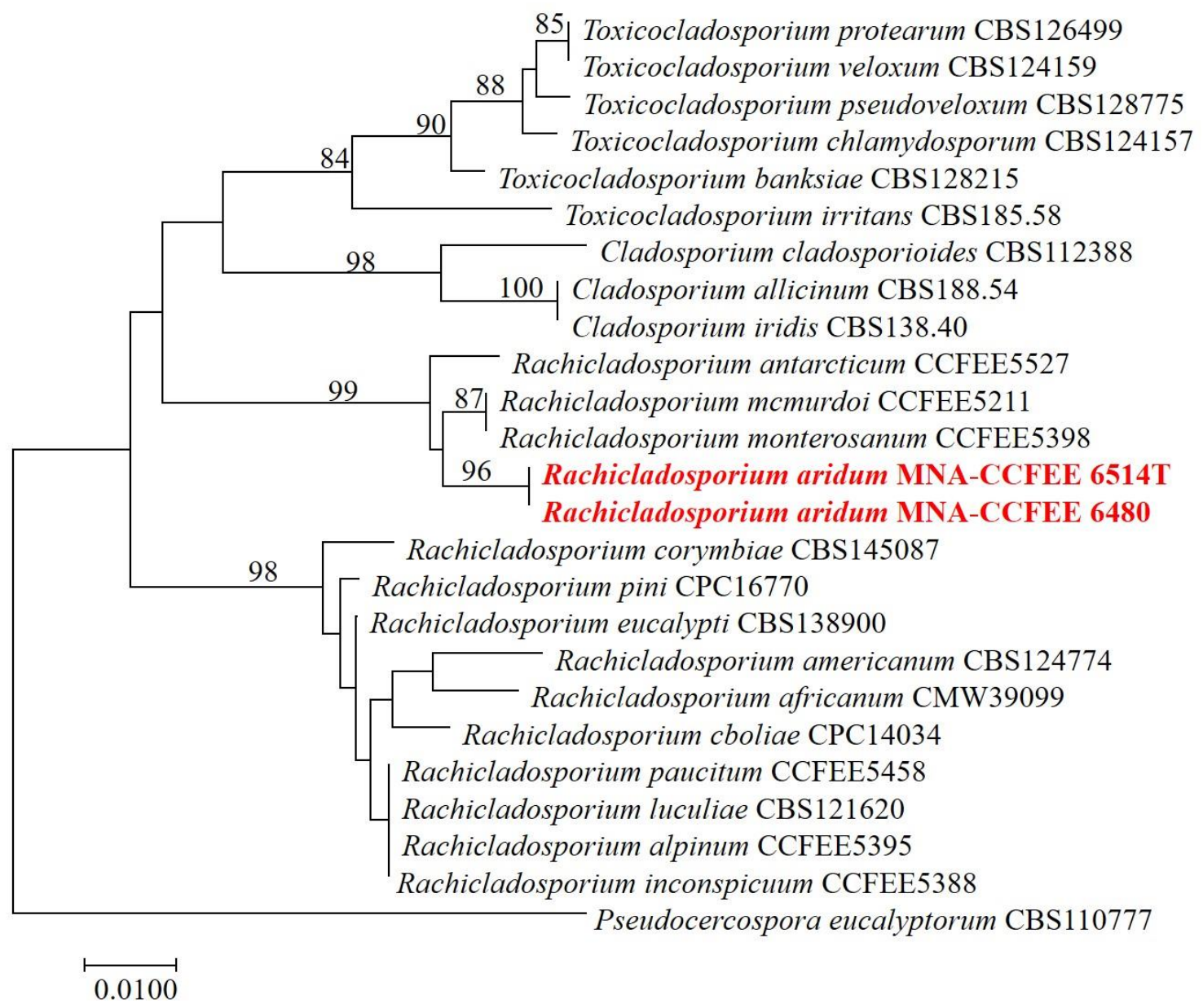

Figure 14 - ITS-LSU-rpb2 (ITS: 1-530; LSU: 531-1417; rpb2: 1418-1686) multi-locus tree constructed using the maximum-likelihood (ML) criterion. The best scoring RAxML tree with a final likelihood value of -19053.72 (2015 sites). The tree was rooted with Pseudocercospora eucalipty (CBS 110777). Estimated base frequencies were as follows: $\mathrm{A}=0.2458414, \mathrm{C}=$ $0.240345, \mathrm{G}=0.2749433, \mathrm{~T}=0.2388703$; substitution rates: $\mathrm{AC}=0.1429208, \mathrm{AG}=0.1356144$, $\mathrm{AT}=0.1416212, \mathrm{CG}=0.09844051, \mathrm{CT}=0.3933481, \mathrm{GT}=0.08805502$; gamma distribution shape parameter $\alpha=0.03569929$. The bootstrap values have been calculated on 1000 pseudo-replicated and values above $80 \%$ are shown. New species is shown in bold red.

The extensive collection from fungi-rich host plants (e.g. Eucalyptus, Rosa, Clematis, palms and bamboo species) would help to reveal new taxa and old taxa that need to be epitypified. Here, we suggest making new collections from the host families for which the fungi-rich hosts are included. In the case of Eucalyptus hosts, collections can be extended to family Myrtaceae instead of focusing only on Eucalyptus, as well as to other families proven to be fungi-rich hosts, such as Arecaceae (Hyde et al. 1998, Fröhlich \& Hyde 1999, Taylor et al. 1999, 2000, Konta et al. 2016, 2020, Thambugala et al. 2017, Wanasinghe et al. 2018b). Moreover, the fungi-rich hosts that have worldwide distribution could also be prioritized for seeking new taxa. For example, in Sri Lanka, a large area of reforested land is occupied by Eucalyptus species (mainly E. camaldulensis, E. grandis, E. robusta fide Bandaratillake 1993), however, no research has been carried out to 
investigate the fungi inhabiting them, including pathogens. Some host species that are geographically restricted (i.e. endemic) could be recognized as a valuable source of new species.

Wanasinghe et al. (2018a) studied the fungi on genus Rosa (Rosaceae) and recognized it as a fungi-rich host genus. Farr \& Rossman (2021) listed 767 and 581 records of coelomycetous and hyphomycetous taxa from Rosa, respectively. Hence, we assume that there could be a large number of undiscovered species from Rosa and its family, Rosaceae. Besides, members of Rosaceae are important in agriculture and in ornamental plant industry thus, cultivated as economic crops. Most edible species are originally temperate crops (e.g. strawberry, apple) but introduced and cultivated in some tropical countries (e.g. strawberry cultivations in Sri Lanka). Even though these species are important as economic crops, only a few studies have been carried out to study their associated fungi, except pathogens (e.g. Cloete et al. 2011). Thus, we conclude that Rosaceae is an important host family to reveal more taxa. Moreover, we predict that there would be interesting relationships between hosts (as an exotic species) with native fungal species in tropical regions.

We have selected Spiraea salicifolia, a member of Rosaceae, from which to collect conidial taxa during our survey. A new taxon, which morphologically resembles asexual taxa in Botryosphaeriaceae, was collected. Morpho-molecular analyses (Figs 18, 19) confirmed that the new collection belongs in Phaeobotryon and formed a distinct clade, and thus it is introduced as a new species, Phaeobotryon spiraeae. Many Rosaceae plants are cultivated as economic crops (e.g. strawberry, apple, pear, loquats) in China, and occur in natural vegetation. Hence, many species may yet to be discovered from China, which could be important as opportunistic pathogens in the future.

Phaeobotryon Theiss. \& Syd., Annls mycol. 13(5/6): 664 (1915)

Theissen \& Sydow (1915) introduced this genus with P. cercidis (Cooke) Theiss. \& Syd. as the type species. The genus was re-visited based on both morphology and phylogeny, which established clear generic boundaries with the members of Botryosphaeriales (Phillips et al. 2013). Species boundaries are also well established and several novel species have been recently introduced (Daranagama et al. 2016, Chen et al. 2019, Pan et al. 2019). The genus is holomorphic and recently introduced species from China are represented by asexual morphs. We assume that novel taxa of Phaeobotryon can be expected from unexplored regions in China and other South East Asia countries which have higher fungal diversity (e.g. Thailand).

Phaeobotryon spiraeae L.X. Zhang \& X.L. Fan sp. nov.

Fig. 15

Index Fungorum number: IF558666; Facesoffungi number: FoF 10495

Holotype - CF 20186828

Etymology - Named after the host genus on which it occurs, Spiraea.

Sexual morph: Undetermined. Asexual morph: Conidiomata pycnidial, stromatic, scattered to gregarious, multiloculate, immersed to erumpent from bark surface. Locules multiple, irregular arrangement with common walls, (430-)530-695(-780) $\mu \mathrm{m}$ (av. $=580 \mu \mathrm{m}, \mathrm{n}=30$ ) in diam., ectostromatic disc and ostiole inconspicuous. Conidiophores reduced to conidiogenous cells. Conidiogenous cells hyaline, smooth, thin-walled, cylindrical to doliiform, holoblastic, phialidic, formed from the cells lining the inner walls. Conidia initially hyaline, becoming dark brown, aseptate, smooth with granular contents, guttulate, thick-walled, oblong to cylindrical, straight, both ends broadly rounded, $(21.0-) 23.5-28.5 \times 8.5-13.5 \mu \mathrm{m}(\mathrm{av} .=26.5 \times 10.5 \mu \mathrm{m}, \mathrm{n}=50)$.

Material examined - China, Beijing City, Huairou District, Labagoumen Primeval Forest, from Spiraea salicifolia, June 2018, X.L. Fan, CF 20186828 holotype, ex-type CFCC 53925.

Other material examined - China, Beijing City, Huairou District, Labagoumen Primeval Forest, from Spiraea salicifolia, June 2018, X.L. Fan, CF 20186829 paratype, ex-paratype CFCC 53926; ibid. CF 20186830, living culture CFCC 53927.

GenBank accession numbers: ITS: OM049420-OM049422; LSU: OM049432-OM049434

Notes - The new collections from Spiraea salicifolia is morphologically and phylogenetically distinct from extant species, thus we introduce it as a new species (Figs 15, 16). 


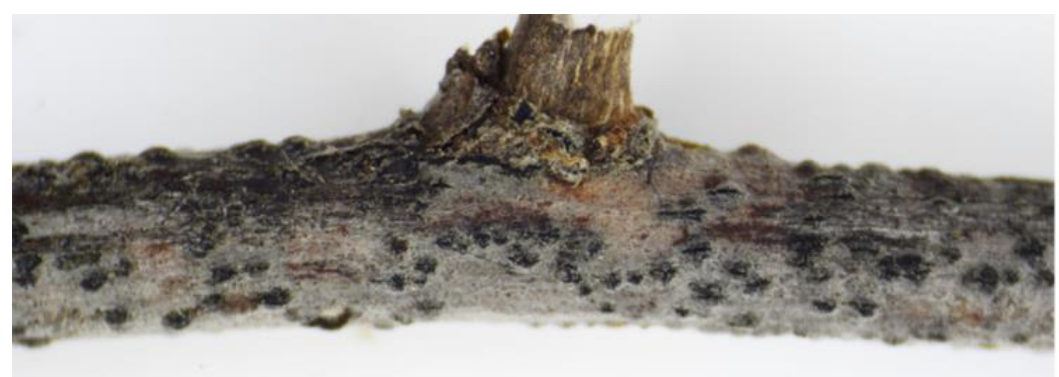

A
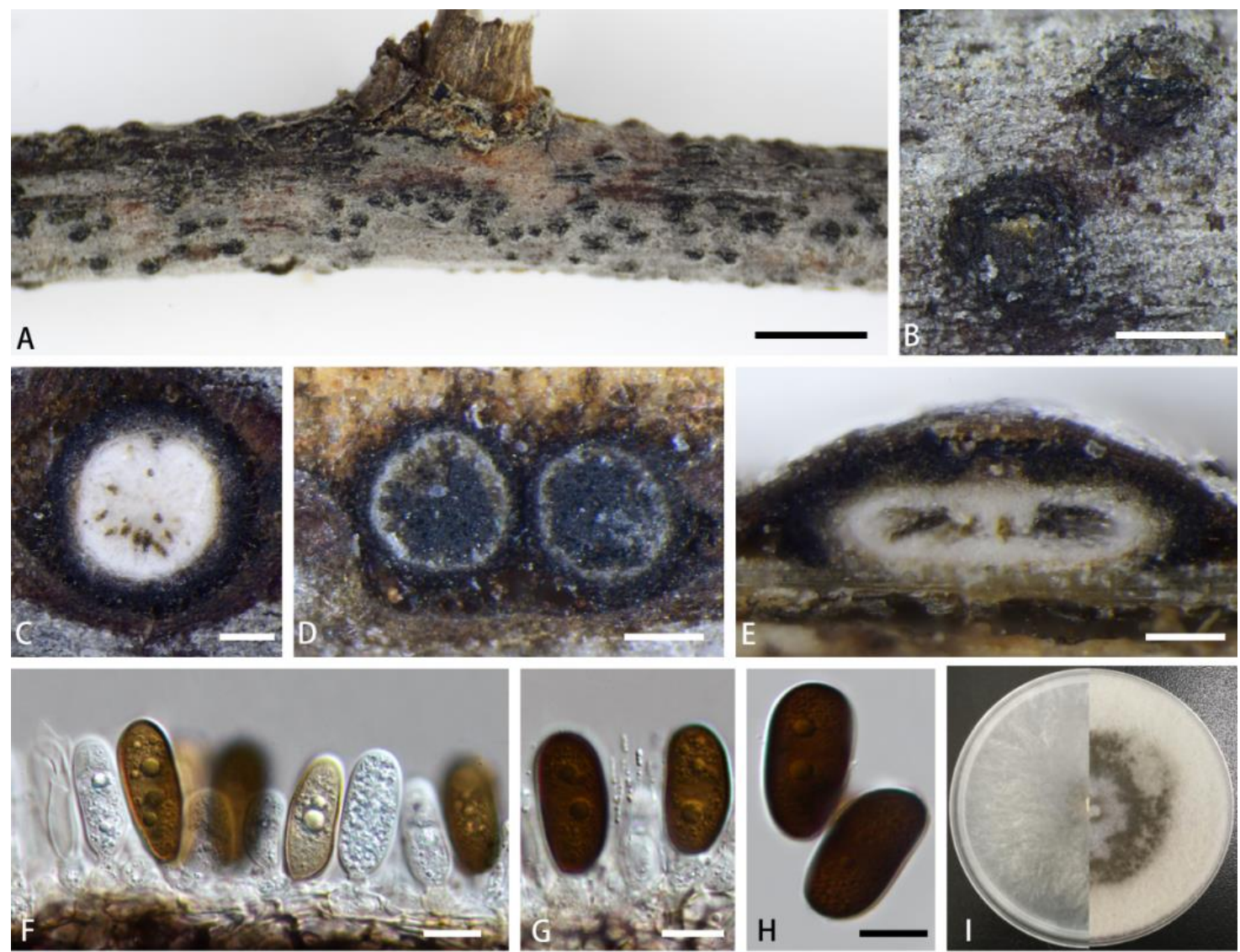

Figure 15 - Phaeobotryon spiraeae (CF 20186828, holotype) from Spiraea salicifolia. A, B Pycnidia on a twig of Spiraea salicifolia. C, D Transverse section of conidiomata. E Longitudinal section through conidioma. F, G Conidia attached to conidiogenous cells. H Conidia. I. Cultures on PDA, surface and reverse views. Scale bars: $A=2 \mathrm{~mm}, \mathrm{~B}=500 \mu \mathrm{m}, \mathrm{C}=$ $100 \mu \mathrm{m}, \mathrm{D}-\mathrm{E}=150 \mu \mathrm{m}, \mathrm{F}-\mathrm{H}=10 \mu \mathrm{m}$.

\section{New taxa from genera that are reported with cryptic species}

The term "cryptic species" is frequently mentioned in systematic works in mycology, but the term has not always been applied correctly, and other times the term has not been mentioned at all, even when the study clearly involves cryptic species. For these reasons, it is important to define the term before discussing how it can impact the estimates of extant species of fungi.

It is well known that cryptic species exist in all groups of organisms. While cryptic species have been variously defined, and often synonymised with sibling species, a good discussion of the concept has been provided by Bickford et al. (2007). Although Bickford et al. (2007) discussed this term in relation to animal species their definition applies equally to all organisms. In that respect they considered that the term "cryptic species" describes distinct species that are erroneously classified (and hidden) under one species name (Bickford et al. 2007). Thus, the term is often applied when species cannot be distinguished reliably by morphology even if they are known to be distinct. Although this is a relatively simple definition, applying the concept in practice can be fraught with difficulties.

For many years, the morphological species concept was the most commonly applied concept for fungi. In some genera, species were also defined according to the host with which they were associated. However, both approaches are now known to lead to misinterpretations of the number of species. Host-association is a misleading character to define a species and application of this concept has led to a gross over-estimation of species. Thus, this practice has long been considered as unsuitable for species definition. On the other hand, the morphological species concept is considered to underestimate species numbers because morphological characters can be very plastic (phenotypic plasticity), and they frequently overlap between species. In this way, the 
morphological species concept, as well as the use of host-association as a character to define species, often define groups of cryptic species (Burnett 2003).

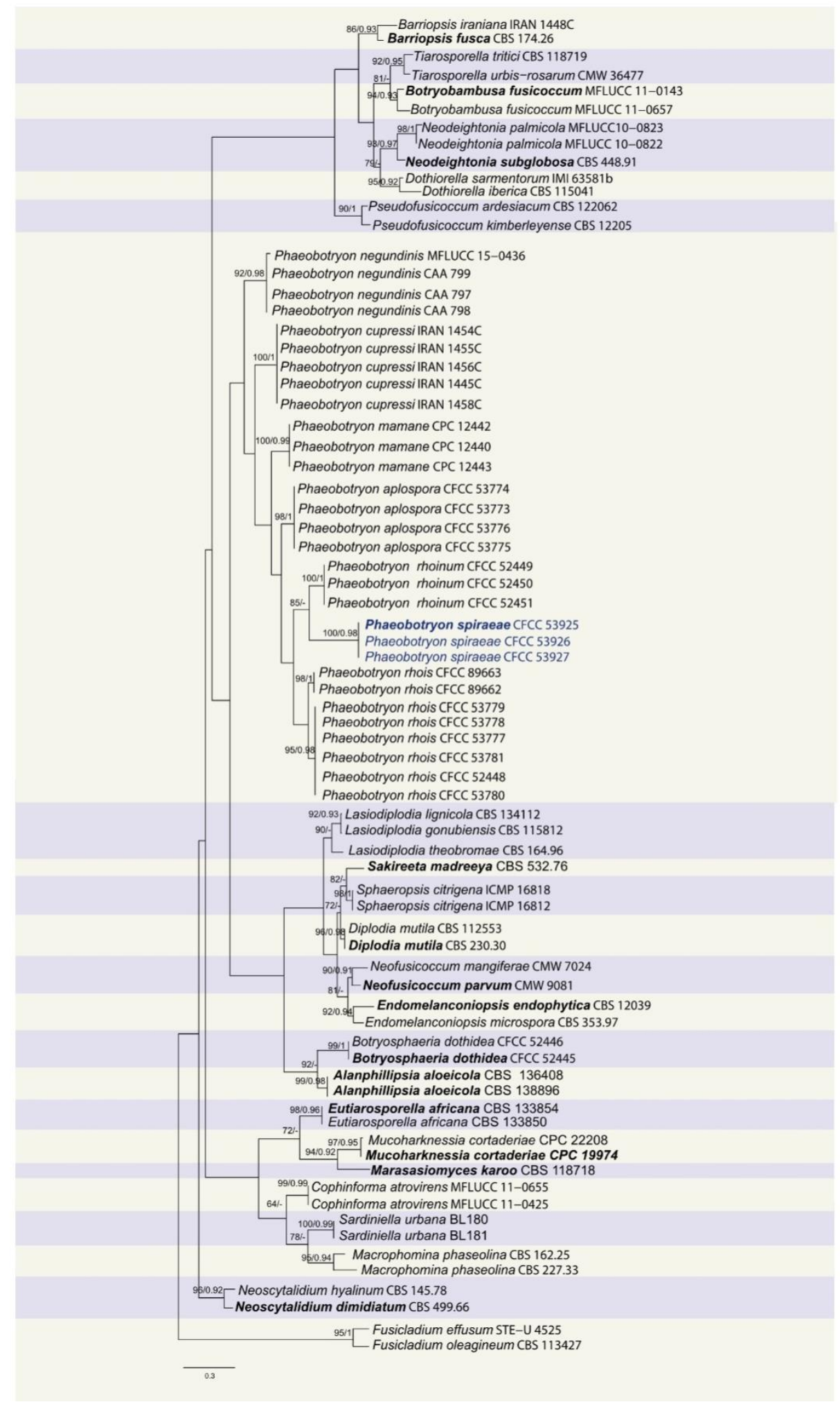

Figure 16 - The best scoring RAxML tree with a final likelihood value of -22601.460384 for combined dataset of ITS, LSU, tefl- $\alpha$ sequence data. The topology and clade stability of the combined gene analyses were compared to the single gene analyses. Numbers above the branches indicate ML bootstraps (left, ML BS $\geq 50 \%$ ) and Bayesian Posterior Probabilities (right, BPP $\geq$ 0.90). The tree is rooted with Fusicladium effusum (STE-U 4525) and Fusicladium oleagineum (CBS 113427). The matrix had 929 distinct alignment patterns with $27.43 \%$ undetermined 
characters and gaps. Estimated base frequencies were as follows: $\mathrm{A}=0.228527, \mathrm{C}=0.263570, \mathrm{G}=$ $0.278846, \mathrm{~T}=0.229057$; substitution rates: $\mathrm{AC}=1.250159, \mathrm{AG}=2.344965, \mathrm{AT}=1.178390, \mathrm{CG}=$ $1.445313, \mathrm{CT}=4.419963, \mathrm{GT}=1.000000$; gamma distribution shape parameter $\alpha=0.259595$. The newly generated sequence is in blue. Ex-type strains are in bold. "-." indicates ML BS $<50 \%$ or BI $\mathrm{PP}<0.90$.

The genus Diaporthe is a notable example where these species complexes occur frequently due to the definition of species based on host-association. While some Diaporthe species are relatively host-specific (generally pathogenic for their respective hosts and less variable at infraspecific level), most of them are species with a broad host range (generally opportunistic pathogens or secondary invaders) (Udayanga et al. 2014a, b). These species often have a high degree of genetic diversity, insomuch as they are frequently regarded as species complexes. Critical analysis of these complexes, well supported with suitable DNA sequence data, often unveils hidden cryptic species (Gomes et al. 2013, Udayanga et al. 2012, 2014a, b). Udayanga et al. (2014b) recognised nine distinct phylogenetic species in the Diaporthe eres species complex (D. alleghaniensis, D. alnea, D. bicincta, D. celastrina, D. eres, D. helicis, D. neilliae, D. pulla and D. vaccinii) occurring on an extensive range of hosts. Therefore, several isolates of Diaporthe that were formerly identified based on their host were shown to represent different taxa. Several other well-known and important species of phytopathogenic fungi represent complexes of cryptic species, to be found in genera such as Calonectria, Dothiorella, Fusarium and Phyllosticta (Cai et al. 2011, Shivas \& Cai 2011). Thus, their accurate identification is of particular importance to national biosecurity agencies that promote plant diseases control and prevent the introduction of exotic phytopathogens.

In many genera of microfungi, the number of morphological characters that can be used to distinguish a species is small and the ranges of differences within each character are also small. Not only that but the phenotypic plasticity of the characters confounds the value of their use. Thus, only a few species can be distinguished on morphology and for this reason taxonomists rely increasingly on a phylogenetic concept for species definitions. In that respect it is clear that mycologists have been applying the concept of cryptic species even if the concept is not actually stated. Returning to the previous Diaporthe example, many Diaporthe species that are morphologically similar have proven to be genetically distinct, which shows how cryptic species can be hidden under the same morphological species. For example, D. rudis and D. australafricana are two closely related species associated with grapevines that, although morphologically similar, occur on different continents, which probably allowed them to accumulate genetic differences due to their geographical isolation (occupation of non-overlapping areas separated by geographical barriers) (van Niekerk et al. 2005, Gomes et al. 2013). In fact, Diaporthe represents a highly complex genus comprising numerous cryptic species, which resulted from either host-association identification or morphology-based identification. However, both of these approaches do not reflect the natural evolutionary history due to the simple and plastic morphological characters. While DNA-based phylogenetic studies on fungi have been applied since the 1980s, the concept of using a DNAbarcoding system was first introduced by Hebert et al. (2003). The original idea was that identifications based on morphology rely on specialist knowledge accumulated over many years of study by individual taxonomists. When those taxonomists retire, their knowledge would be lost. However, an identification system based on a DNA barcode can be applied by anyone with a basic training in working with DNA and who has access to a sequencer. The concept was soon adopted by fungal taxonomists who ultimately chose the ITS cluster as the barcoding locus, with the proviso that other loci would be necessary to resolve cryptic species complexes and these extra loci would not necessarily be the same for all groups of fungi.

Taylor et al. (2000) summarized the challenges associated with the phylogenetic species concept (PSC) and its operational version, the phylogenetic species recognition (PSR), namely the fact that "individuals are grouped very well, but the decision about where to place the limit of the species is subjective". Through the analysis of variable nucleic acid characters, PSC and PSR are 
the concepts that closer recognize species consistent with the Evolutionary Species Concept (ESC), since changes in gene sequences occur and can be noticed before any changes in mating behaviour or morphology. Nevertheless, using DNA barcodes to diagnose species can be challenging for polymorphic genes within certain species since one would not know if the gene is polymorphic within a species, or fixed for alternate alleles in two species. For this reason, mycologists have increasingly relied on phylogenetic species concepts based on multiple loci, since by relying on the concordance of more than one gene genealogy, PSC and PSR can prevent the subjectivity of determining the limits of a phylogenetic species. This concept, which was proposed by Avise \& Ball (1990) and named by Mayden (1997), is known in its operational version as the Genealogical Concordance Phylogenetic Species Recognition (GCPSR). GCPSR relies on essentially three aspects: 1) comparison of more than one gene genealogy; 2) parts of certain genes can be used to construct genealogies since recombination does not occur within the gene; 3 ) the concordances on the topology of different gene trees result from the fixation of formerly polymorphic loci. Thus, concordant branches on the genealogy of different genes define the limits of a phylogenetic species (Taylor et al. 2000). Several examples of cryptic species in different genera, besides the Diaporthe examples referred to above, were described based on GCPSR. The application of this concept has great implications for accurate species recognition and resolution of species complexes, namely in common plant pathogenic genera, such as Calonectria (Lombard et al. 2010), Cercospora (Groenewald et al. 2005, Crous et al. 2006), Fusarium (Aoki et al. 2005, Summerell et al. 2010, 2011, Summerell \& Leslie 2011), besides other genera where phylogenetic cryptic species are consistent with allopatric speciation as discussed in Diaporthe. Such genera include Cladosporium (Bensch et al. 2012), Colletotrichum (Crouch et al. 2009, Phoulivong et al. 2010, Damm et al. 2012a, b), Harknessia (Crous et al. 2012), Ilyonectria (Cabral et al. 2012a, b) and Phyllosticta (Glienke et al. 2011, Wikee et al. 2011, Wang et al. 2012) amongst others.

Although several studies have shown that multigene analyses are important for aiding in species recognition, insomuch that they often identify cryptic species. However, interpretation of the outcomes of such studies can be challenging, especially if species variation is simply due to natural polymorphism within gene sequences. As stated many years ago by Darwin (1859), variation within a species is essential and is one of the key factors at the base of his theory of evolution. Thus, individuals in a population must vary significantly from one another and much of this variation must be heritable so that individuals less suited to the environment are less likely to survive and less likely to reproduce; individuals more suited to the environment are more likely to survive and more likely to reproduce and leave their heritable traits to future generations. This is the basis of natural selection, which in turn is the basis of speciation events. Unfortunately, in fungi, this aspect of variation within a population has often been ignored by fungal taxonomists and minor variations have been interpreted as indicating species.

\section{Conclusion}

The question, 'what is the number of species in Kingdom Fungi?' is always followed by the question 'where and how do we find the missing species? Hawksworth (1991) predicted that molecular tools, e.g. DNA sequence data, are vital in species identification, in phylogeny and in linking sexual and asexual morphs. As the usage of DNA sequences in species identification has become more popular in the last decade, a large number of cryptic species have been introduced. Moreover, many novel taxa have been introduced from tropical and subtropical regions such as Asia (Hyde et al. 2020) (Fig. 17). These records indicate that extensive studies in tropical and subtropical regions are essential to discover missing taxa, and it is important to epitypify the already-described taxa.

Different life modes from different habitats are also essential to study using extensive collections. We have introduced one new genus and nine new species from different life modes that are regarded as overlooked or less studied, viz. lichens with pycnidia, rock-inhabiting fungi and lichenicolous taxa. In addition, fungicolous fungi, indoor fungi, coprophilous fungi and fungi associated with lower plants (e.g. Bryophytes) are also important to study thoroughly. It is 
necessary to expand the research on well-studied life modes and habitats. For example, Sri Lanka is an island with rich mangrove diversity, but the knowledge of fungal taxa inhabiting those mangroves is lacking. However, in other regions, fungi associated with mangroves are well studied.

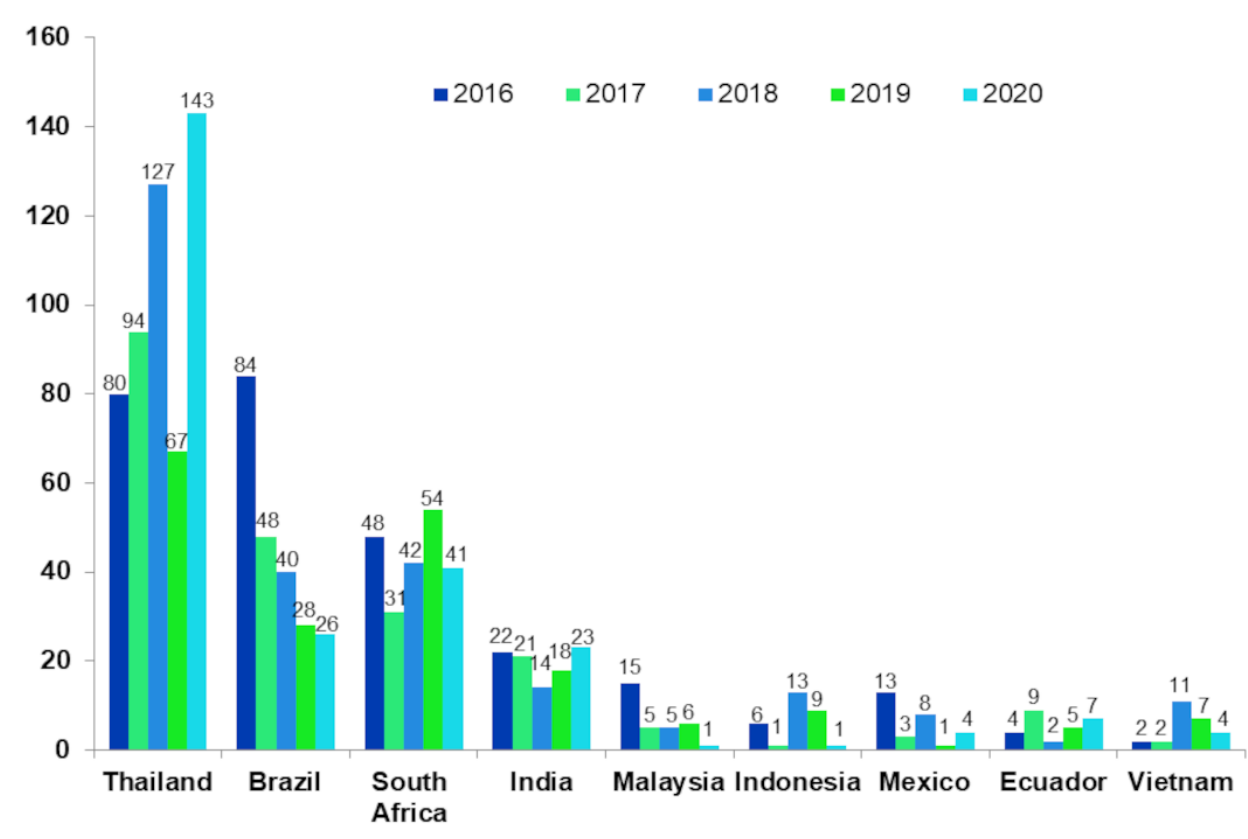

Figure 17 - Number of novel taxa described from tropical countries

\section{Lesser studied habitats}

Fungi play significant roles in different ecosystems. Many studies have focused on natural ecosystems or habitats such as natural forests, fresh-water ecosystems (including both lentic or lotic) and marine environments (e.g. estuaries). In addition to the fungi in natural ecosystems, considerable research has focused on agricultural lands and forest plantations. Hence, a large number of species have been reported from these ecosystems or habitats. Extensively studied ecosystems still contain a large number of undiscovered species. For example, Luo et al. (2019) introduced three new genera and 47 new species of Sordariomycetes from freshwater bodies in China. Rashmi et al. (2019) mentioned that foliar endophytic species are the broadly studied group among other endophytic fungi. Asian countries (such as China, India), European countries (such as Germany, Spain and the UK), Brazil and the USA regions have been thoroughly studied (Rashmi et al. 2019). However, the fungi colonize in other parts of the plants, unculturable taxa and slow growing taxa need to be studied based on proper methods, such as culture-independent methods, such as high-throughput sequencing (Wijayawardene et al. 2021a). Sun et al. (2019) comprehensively reviewed the current status of fungicolous taxa and listed 1552 species. Moreover, Sun et al. (2019) regarded that it is essential to carry out further studies to 'understand their biology, ecological aspects, origin and divergence, host-specificity and application in biocontrol'.

Large ecosystems may also harbour different microhabitats that are distinct from their surroundings. These habitats might be important in revealing undescribed species. For example, swamps or seasonal ponds in evergreen rain forests provide distinct environmental conditions, and so they may be home for different species that are distinct from those inhabiting the neighbouring environments. Moreover, the concept of endemism (or endemic fungal species) has largely been ignored by mycologists, and so species inhabiting particular microhabitats would be an interesting topic for future studies.

\section{Environmental sequencing and its importance in new species detection}

Characterization of microbial diversity is a key issue, since the composition of natural microbial communities is known to be ecologically relevant. In the past, investigations of the 
diversity and functioning of microbial communities have been based on isolation and cultivation of microbes and their characterization through direct observation of distinct morphologies (e.g. Guba 1961). These studies have allowed for a preliminary taxonomical classification. However, by showing that the number of cells observed microscopically far outweighed the number of colonies growing on a petri plate (Amann 1911), it was confirmed that this type of analysis cannot be considered an accurate measure of microbial diversity. This fact clearly hinders our ability to characterize them taxonomically, and thus our knowledge of the microbial world.

Environmental genomics or metagenomics is the term applied to the study, of complex fungal communities sampled directly from the environment. There is no need to perform previous culturing or isolation of inhabiting taxa thus directly used to screen the taxa. Several metabarcoding techniques have been developed since the introduction of high-throughput sequencing (HTS) techniques (Margulies et al. 2005, Shendure et al. 2005), which offer high-speed and low-cost massive sequencing services. Numerous pipelines such as PIPITS (Gweon et al. 2015), CloVR-ITS (White et al. 2013), PipeCraft (Anslan et al. 2017), and FindFungi (Donovan et al. 2018) have been developed to generate sequence data linked to the environmental samples. Baldrian et al. (2021) discussed the future possibilities of using HTS in fungal diversity studies and emphasized the magnitude of undiscovered, voucher less taxa which are important to reveal missing species.

The possibility of obtaining DNA sequence information from environmental samples has allowed for the identification of uncultured microbes, regardless of their viability (Amann et al 1995, Hongsanan et al. 2018). Such analyses have revealed an unexpected hidden diversity that had never been seen before through traditional cultivation methods. Metabarcoding studies of soil (Tedersoo et al. 2014, 2017, 2021, Bahram et al. 2018), deep sea water and sediments (Singh et al. 2010, Luo et al. 2020) and plant litter (Bálint et al. 2014, Duarte et al. 2020) revealed 'dark taxa' which have not been discovered before. Tennakoon et al. (2021) strongly suggested that future studies to discover plant litter fungi must depend on high-throughput sequencing.

Nevertheless, naming the sequences or operational taxonomic units (OTUs) generated from environmental studies (and voucher less species) have been a controversial topic. Hibbett et al. (2011), Lücking \& Hawksworth (2018) and Lücking et al. (2020) encouraged to proceed with sequence-based nomenclature since it would be the best solution to address the sequences generated from environmental sequencing. However, Hongsanan et al. (2018) and Thines et al. (2018) discussed its disadvantages such as the short-length sequences and acceptable value for similarity threshold. However, Tedersoo et al. (2020) broadly discussed about the perspectives of long read sequences in future ecological studies and mentioned that techniques such as 'PacBio and nanopore sequencing are still relatively costly, require large amounts of high-quality starting material, and commonly need specific solutions in various analysis steps. Despite these challenges, long-read sequencing technologies offer high-quality, cutting-edge alternatives for testing hypotheses about microbiome structure and functioning as well as assembly of eukaryote genomes from complex environmental DNA samples. A provisional name system similar to bacterial nomenclature would be the most suitable system for future studies (Hibbett et al. 2011, Lücking et al. 2021).

Murray \& Stackebrandt (1995) suggested a provisional category for classifying uncultured taxa, which is called as Candidatus. Nevertheless, this rank has not been widely accepted by the scientific community, claiming the technical limitations and lack of priority for Candidatus names in the official nomenclature (Konstantinidis et al. 2017). Currently, cutting-edge sequencing techniques and computational methods for genome assembly make it feasible for high-quality taxonomic descriptions of uncultivated microbes, as well as for more realistic microbial diversity analyses.

Consequently, a new genome-based taxonomy is emerging based on these "uncultured genome sequences", although there is a clear need for standards that establish widely adopted procedures and standards. Publication of explicit and well-documented guidelines will facilitate the convergence of traditional and genome-based taxonomies to develop a unique, comprehensive 
taxonomic classification system that will include uncultivated microbes with validly published names. However, even if some characters can be inferred from genome sequences, it should be noted that the lack of living cultures limits the information traditionally required for full taxonomic descriptions (e.g., morphologically, physiologically, biochemically). Moreover, the International Code of Nomenclature for Algae, Fungi and Plant (ICNafp) demands the preservation of type material (Turland et al. 2018)

Additionally, considering that all organisms are "culturable" in their natural environment, genomes mined from environmental samples could assist to improve culturing efforts through the coded information found on these sequences. For instance, specific nutrient requirements or other growing condition determinants could be extracted from genomic data. In conclusion, this genomeguided approach has the potential to enhance current isolation and cultivation strategies for taxa classified as unculturable, enriching our repertoire of microbiological techniques, and providing access to previously hidden metabolic diversity.

\section{Acknowledgements}

This work was supported by the National Natural Science Foundation of China (No. NSFC 31950410558, NSFC 31760013), Department of Science and Technology of Yunnan Province (No. 2018FB050), the State Key Laboratory of Functions and Applications of Medicinal Plants, Guizhou Medical University (No. FAMP201906K); Science and Technology Department of Guizhou Province (QKHRCPT[2017]5101) and High-Level Talent Recruitment Plan of Yunnan Provinces ("Young Talents" Program and "High-End Foreign Experts" Program). Nalin. N. Wijayawardene thanks Dr. Paul M. Kirk and Prof. Rafael Castaneda for their supports for nomenclatural issues and correcting descriptions. AJL Phillips and DS Pereira acknowledge the support from UIDB/04046/2020 and UIDP/04046/2020 Centre grants from FCT, Portugal (to BioISI). Laura Selbmann and Claudia Coleine wish to thank the Italian National Program for Antarctic Research for funding sampling campaigns and research activities in Italy in the frame of PNRA projects. The Italian Antarctic National Museum (MNA) is kindly acknowledged for financial support to the Culture Collection of Fungi From Extreme Environments (MNA-CCFEE; University of Tuscia, Italy) of the Mycological Section of the MNA, where the fungus (Rachicladosporium aridum) described in this study is stored. AF is greatly indebted to Dr. Javier Etayo (Pamplona) for taxonomic discussion, and also to staff of the Herbario Nacional de Bolivia, Instituto de Ecología, Universidad Mayor de San Andrés, La Paz, for their cooperation. The research of AF was financially supported by the National Science Centre (NCN) in Poland (DEC2013/11/D/NZ8/03274). Saowaluck Tibpromma would like to thank the International Postdoctoral Exchange Fellowship Program (number Y9180822S1), CAS President's International Fellowship Initiative (PIFI) (number 2020PC0009), China Postdoctoral Science Foundation and the Yunnan Human Resources, and Social Security Department Foundation for funding her postdoctoral research. Samantha C. Karunarathna thanks CAS President's International Fellowship Initiative (PIFI) for funding his postdoctoral research (number 2018PC0006) and the National Science Foundation of China (NSFC) for funding this research work under project code 31750110478.

\section{References}

Adikaram NKB, Yakandawala DMD. 2020 - A checklist of plant pathogenic fungi and Oomycota in Sri Lanka. Ceylon Journal of Science 49(1), 93-123. Doi 10.4038/cjs.v49i1.7709

Ahti T. 2000 - Cladoniaceae. Flora Neotropica 78, 1-362.

Alstrup V, Cole MS. 1998 - Lichenicolous fungi of British Columbia. Bryologist 10(2), 221-229. Doi $10.2307 / 3244200$

Amann J. 1911 - Die direkte Zählung der Wasserbakterien mittels des Ultramikroskops. Centralbl. Bakteriol. II Abt 29, 381-384.

Amann RI, Ludwig W, Schleifer KH. 1995 - Phylogenetic identification and in situ detection of individual microbial cells without cultivation. Microbiology Reviews 59, 143-169. 
Anslan S, Bahram M, Hiiesalu I, Tedersoo L. 2017 - PipeCraft: Flexible open-source toolkit for bioinformatics analysis of custom high-throughput amplicon sequencing data. Molecular Ecology Resources 17(6), e234-40. Doi: 10.1111/1755-0998.12692

Aoki T, O'Donnell K, Scandiani MM. 2005 - Sudden death syndrome of soybean in South America is caused by four species of Fusarium: Fusarium brasiliense sp. nov., $F$. cuneirostrum sp. nov., F. tucumaniae, and F. virguliforme. Mycoscience 46(3), 162-183. Doi 10.1007/s10267-005-0235-y

Aptroot A, Cáceres MES. 2017 - New Arthoniales from Amapá (Amazonian North Brazil) show unexpected relationships. Lichenologist 49, 607-615. Doi 10.1017/S0024282917000500

Aptroot A, Lücking R. 2016 - A revisionary synopsis of the Trypetheliaceae (Ascomycota: Trypetheliales). Lichenologist 48(6), 763-982. Doi 10.1017/S0024282916000487

Aptroot A, Schiefelbein U. 2003 - Additional species of Cheiromycina (lichenized hyphomycetes), with a key to the known species. Mycological Research 107(1), 104-107. Doi 10.1017/S0953756202007128

Aptroot A, Sipman HJM. 1993 - Musaespora, a genus of pyrenocarpous lichens with campylidia, and other additions to the foliicolous lichen flora of New Guinea. Lichenologist 25, 121-135. Doi 10.1006/lich.1993.1021

Aptroot A, Sipman HJM. 2011 - Sporodochiolichen, a new genus of tropical hyphomycetous lichens. Lichenologist 43, 357-362. Doi 10.1017/S0024282911000314

Aptroot A, Lücking R, Sipman HJM, Umaña J et al. 2008 - Pyrenocarpous lichens with bitunicate asci: a first assessment of the lichen biodiversity inventory in Costa Rica. Bibliotheca Lichenologica 97, 1-162.

Aptroot A, Ferraro LI, Cáceres MES. 2014 - New pyrenocarpous lichens from NE Argentina. Lichenologist 46, 95-102. Doi 10.1017/S0024282913000716

Aptroot A, Souza MF, Spielmann AA. 2020 - New lichen species from the Pantanal in Mato Grosso do Sul, Brazil. Archive for Lichenology 20, 1-9.

Avise JC, Ball RM, Jr. 1990 - Principles of genealogical concordance in species concepts and biological taxonomy. In Oxford Surveys in Evolutionary Biology (D. Futuyma and J. Antonovics, Eds.) 7, 45-67.

Bahram M, Hildebrand F, Forslund SK, Anderson JL et al. 2018 - Structure and function of the global topsoil microbiome. Nature 560, 233-237. Doi 10.1038/s41586-018-0386-6

Baldrian P, Větrovský T, Lepinay C, Kohout P. 2021 - High-throughput sequencing view on the magnitude of global fungal diversity. Fungal Diversity. Doi 10.1007/s13225-021-00472

Bálint M, Schmidt PA, Sharma R, Thines M et al. 2014 - An illumina metabarcoding pipeline for fungi. Ecology and Evolution 4(13), 2642-2653. Doi 10.1002/ece3.1107

Bandaratillake HM. 1993 - Eucalyptus plantations in Sri Lanka: environmental, social, economic and policy issues. Reports submitted to the regional expert consultation on Eucalyptus. http://www.fao.org/3/ac772e/ac772e01.html

Batista AC, Maria HDS. 1965 - Caprettia, novo gênero de ascoliquen, em homenagem ao micologo Venezuelano, Corrado Capretti. Atas do instituto de micologia da universidade do recife 2, 375-382.

Bensch K, Braun U, Groenewald JZ, Crous PW. 2012 - The genus Cladosporium. Studies in Mycology 72, 1-401. Doi 10.3114/sim0003

Bensch K, Groenewald JZ, Braun U, Dijksterhuis J et al. 2015 - Common but different: The expanding realm of Cladosporium. Studies in Mycology 82, 23-74.

Doi 10.1016/j.simyco.2015.10.001

Bhunjun CS, Phukhamsakda C, Jayawardena RS, Jeewon R et al. 2021 - Investigating species boundaries in Colletotrichum. Fungal Diversity 107(1), 107-127.

Doi 10.1007/s13225-021-00471-z

Bickford D, Lohman D, Sodhi N, Ng P et al. 2007 - Cryptic species as a window on diversity and conservation. Trends in Ecology \& Evolution 22, 148-155. Doi 10.1016/j.tree.2006.11.004 
Boonmee S, Phookamsak R, Hongsanan S, Doilom M et al. 2017 - Mycosphere notes 51-101. Revision of genera in Perisporiopsidaceae and Pseudoperisporiaceae and other Ascomycota genera incertae sedis. Mycosphere 8(10), 1695-1801.

Burnett JH. 2003 - Fungal populations and species. Oxford University Press, Oxford.

Cabral A, Groenewald JZ, Rego C, Oliveira H et al. 2012a - Cylindrocarpon root rot: multi-gene analysis reveals novel species within the Ilyonectria radicicola species complex. Mycological Progress 11(3), 655-688. Doi 10.1007/s11557-011-0777-7

Cabral A, Rego C, Nascimento T, Oliveira H et al. 2012b - Multi-gene analysis and morphology reveal novel Ilyonectria species associated with black foot disease of grapevines. Fungal Biology 116(1), 62-80. Doi 10.1016/j.funbio.2011.09.010

Cáceres MES, Aptroot A. 2016 - First inventory of lichens from the Brazilian Amazon in Amapá State. Bryologist 119, 250-265. Doi 10.1639/0007-2745-120.2.202

Cáceres MES, Aptroot A, Ertz D. 2014 - New species and interesting records of Arthoniales from the Amazon, Rondônia, Brazil. Lichenologist 46, 573-588.

Doi $10.1017 /$ S0024282914000036

Cáceres MES, Aptroot A, Mendonça CO, Santos LA et al. 2017 - Sprucidea, a further new genus of rain forest lichens in the family Malmideaceae (Ascomycota). Bryologist 120, 202-211.

Doi 10.1639/0007-2745-120.2.202

Cai F, Druzhinina IS. 2021 - In honor of John Bissett: authoritative guidelines on molecular identification of Trichoderma. Fungal Diversity 107, 1-69.

Doi 10.1007/s13225-020-00464-4

Cai L, Udayanga D, Manamgoda DS, Maharachchikumbura SSN et al. 2011 - The need to carry out re-inventory of plant pathogenic fungi. Tropical Plant Pathology 36, 205-213.

Doi 10.1590/S1982-56762011000400001

Chang HS. 1995 - Notes on Taiwan dematiaceous hyphomycetes, some species of the genera Exserticlava, Craspedodidymum and Hermatomyces. Botanical Bulletin-Academia Sinica Taipei 1(36), 243-6.

Chaturvedi V, de Hoog GS. 2020 - Onygenalean fungi as major human and animal pathogens. Mycopathologia 185, 1-8. Doi 10.1007/s11046-020-00428-x

Cheewangkoon R, Groenewald JZ, Summerell BA, Hyde KD et al. 2009 - Myrtaceae, a cache of fungal biodiversity. Persoonia 23, 55-85. Doi 10.3767/003158509X474752

Chen J, Hao X, Liu X, Liu Z et al. 2019 - Identification of caragana arborescens shoot blight disease caused by Phaeobotryon caraganae sp. nov. (Botryosphaeriales) in China. European Journal of Plant Pathology 155(2), 537-44. Doi 10.1007/s10658-019-01789-w

Chomnunti P, Schoch CL, Aguirre-Hudson B, Ko Ko TW et al. 2011 - Capnodiaceae. Fungal Diversity 51, 103-134. Doi 10.1007/s13225-011-0145-6

Cloete M, Fourie PH, Damm U, Crous PW et al. 2011 - Fungi associated with die-back symptoms of apple and pear trees, a possible inoculum source of grapevine trunk disease pathogens. Phytopathologia Mediterranea 1(50), 176-90. Doi 10.14601/Phytopathol_Mediterr-9004

Cole M, Hawksworth D. 2004 - Lichenoconium christiansenii sp. nov. from Nodobryoria abbreviata (Parmeliaceae) in the Pacific Northwest, with a key to the known lichenicolous species. Lichenologist 36(1), 1-6. Doi 10.1017/S0024282904013970

Coppins BJ. 1983 - A taxonomic study of the lichen genus Micarea in Europe. Bulletin of the British Museum (Natural History). Botany Series 11(2), 17-214.

Doi 10.1017/S0024282984000372

Crouch JA, Clarke BB, Hillman BI. 2009 - What is the value of ITS sequence data in Colletotrichum systematics and species diagnosis? A case study using the falcate-spored graminicolous Colletotrichum group. Mycologia 101(5), 648-656. Doi 10.3852/08-231

Crous PW, Braun U, Schubert K, Groenewald JZ. 2007 - Delimiting Cladosporium from morphologically similar genera. Studies in Mycology 1(58), 33-56.

Doi 10.3114/sim.2007.58.02 
Crous PW, Groenewald JZ, Groenewald M, Caldwell P. 2006 - Species of Cercospora associated with grey leaf spot of maize. Studies in Mycology 55, 189-197. Doi 10.3114/sim.55.1.189

Crous PW, Summerell BA, Shivas RG, Groenewald AJ et al. 2012 - A re-appraisal of Harknessia (Diaporthales), and the introduction of Harknessiaceae fam. nov. Persoonia 28, 49-65.

Doi 10.3767/003158512X639791

Crous PW, Wingfield MJ, Cheewangkoon R, Carnegie AJ et al. 2019 - Foliar pathogens of eucalypts. Studies in Mycology 94, 125-298. Doi 10.1016/j.simyco.2019.08.001

Crous PW, Wingfield MJ, Schumacher RK, Akulov A et al. 2020 - New and interesting fungi. 3. Fungal Systematics and Evolution 6, 157-231. Doi 10.3114\%2Ffuse.2020.06.09

Czarnota P, Guzow-Krzemińska B. 2012 - ITS rDNA data confirm a delimitation of Bacidina arnoldiana and $B$. sulphurella and support a description of a new species within the genus Bacidina. Lichenologist 44, 743-755. Doi 10.1017/S0024282912000515

Damm U, Cannon PF, Woudenberg JH, Crous PW. 2012a - The Colletotrichum acutatum species complex. Studies in Mycology 73, 37-113. Doi 10.3114/sim0010

Damm U, Cannon PF, Woudenberg JH, Johnston PR et al. 2012b - The Colletotrichum boninense species complex. Studies in Mycology 73, 1-36. Doi 10.3114/sim0002

Damm U, Woudenberg JHC, Cannon PF, Crous PW 2009 - Colletotrichum species with curved conidia from herbaceous hosts. Fungal Diversity 39, 45-87.

Daranagama DA, Thambugala KM, Campino B, Alves A et al. 2016 - Phaeobotryon negundinis sp. nov. (Botryosphaeriales) from Russia. Mycosphere 1(7) 933-41.

Doi $10.5943 / \mathrm{mycosphere/si/1b/2}$

Darwin C. 1809-1882 [1859] - On the origin of species by means of natural selection, or preservation of favoured races in the struggle for life. London: John Murray.

De Leo F, Criseo G, Urzi C. 1996 - Impact of surrounding vegetation and soil on the colonization of marble statues by dematiaceous fungi. In Proceeding of the eighth international congress on deterioration and conservation of stone 625-630.

Delgado G, Koukol O, Heredia G, Piepenbring M. 2020 - Texas microfungi: Hermatomyces amphisporus (Pleosporales, Dothideomycetes) revisited. Czech mycology 72, 95-107.

Doi 10.33585/cmy.72107

DeLong JDC. 1996 - Defining biodiversity. Wildlife society Bulletin 1, 738-49.

Doi 10.1007/BF00044642

Diakumaku E, Gorbushina AA, Krumbein WE, Panina L et al. 1995 - Black fungi in marble and limestones - an aesthetical, chemical and physical problem for the conservation of monuments. Science of the Total Environment 167(1-3), 295-304.

Doi 10.1016/0048-9697(95)04590-W

Diederich P. 1997 - Lichenicolous fungi in the tropics. Bibliotheca Lichenologica 68, 215-221.

Diederich P. 2003 - New species and new records of American lichenicolous fungi. Herzogia 16, 41-90.

Diederich P, Common RS, Braun U, Heuchert B et al. 2019 - Lichenicolous fungi from Florida growing on Graphidales. Plant and Fungal Systematics 64(2), 249-282.

Doi 10.2478/pfs-2019-0021

Diederich P, Lawrey JD, Ertz D. 2018 - The 2018 classification and checklist of lichenicolous fungi, with 2000 non-lichenized, obligately lichenicolous taxa. Bryologist 121, 340-425. Doi 10.1639/0007-2745-121.3.340

Doilom M, Dissanayake AJ, Wanasinghe DN, Boonmee S et al. 2017 - Microfungi on Tectona grandis (teak) in Northern Thailand. Fungal Diversity 82(1), 107-182.

Doi 10.1007/s13225-016-0368-7

Dong W, Wang B, Hyde KD, Kenzie EHM et al. 2020 - Freshwater Dothideomycetes. Fungal Diversity 105(1), 319-575. Doi 10.1007/s13225-020-00463-5

Donovan PD, Gonzalez G, Higgins DG, Butler G, Ito K. 2018 - Identification of fungi in shotgun metagenomics datasets. PLoS One 13(2), e0192898. Doi 10.1371/journal.pone.0192898 
Duarte S, Wurzbacher C, Seena S. 2020 - Metabarcoding of litter-associated fungi and bacteria in methods to study litter. Springer cham. 339-346. Doi 10.1007/978-3-030-30515-4_37

Earland-Bennett PM, Hawksworth DL. 2005 - The first lichen-forming species of Psammina, P. palmata sp. nov., with notes on the status of Cheiromycina and Pycnopsammina. Lichenologist 37, 191-197. Doi 10.1017/S0024282905015203

Egidi E, De Hoog GS, Isola D, Onofri S et al. 2014 - Phylogeny and taxonomy of meristematic rock-inhabiting black fungi in the Dothideomycetes based on multi-locus phylogenies. Fungal Diversity 65(1), 127-165. Doi 10.1007/s13225-013-0277-y

Ekanayaka AH, Hyde KD, Gentekaki E, McKenzie EH et al. 2019 - Preliminary classification of Leotiomycetes. Mycosphere 10(1), 310-489. Doi 10.5943/mycosphere/10/1/7

Ekman S. 1996 - Proposal to conserve the name Bacidina against Lichingoldia and Woessia (lichenized Ascomycotina). Taxon 45, 687-688.

Ellis MB. 1971 - Demattaceous Hyphomycetes. Commonwealth Mycological Institute, Kew.

Ertz D, Bungartz F, Diederich P, Tibell L. 2011 - Molecular and morphological data place Blarneya in Tylophoron (Arthoniaceae). Lichenologist 43, 345-356.

Doi 10.1017/S002428291100020X

Ertz D, Diederich P. 2015 - Dismantling melaspileaceae: A first phylogenetic study of Buelliella, Hemigrapha, Karschia, Labrocarpon and Melaspilea. Fungal Diversity 71(1), 141-164.

Doi 10.1007/s13225-015-0321-1

Ertz D, Fischer E, Killmann D, Razafindrahaja T et al. 2013 - Savoronala, a new genus of Malmideaceae (Lecanorales) from Madagascar with stipes producing sporodochia. Mycological Progress 12, 645-656. Doi 10.1007/s11557-012-0871-5

Ertz D, Sanderson N, Łubek A, Kukwa M. 2018 - Two new species of Arthoniaceae from oldgrowth European forests, Arthonia thoriana and Inoderma sorediatum, and a new genus for Schismatomma niveum. Lichenologist 50, 161-172. Doi 10.1017/S0024282917000688

Etayo J. 2002 - Aportación al conocimiento de los hongos liquenícolas de Colombia. Bibliotheca Lichenologica 84, 1-154.

Etayo J. 2017 - Hongos liquenícolas de Ecuador. Opera lilloana 50, 1-535.

Etayo J, Aptroot A, Cáceres MEDS. 2020 - New lichenicolous fungi from Brazil, with a checklist of all lichenicolous fungi known from Brazil. Bryologist 123(3), 483-91.

Doi 10.1639/0007-2745-123.3.483

Etayo J, Flakus A, Suija A, Kukwa M. 2015 - Macroskyttea parmotrematis gen. et sp. nov. (Helotiales, Leotiomycetes, Ascomycota), a new lichenicolous fungus from Bolivia. Phytotaxa 224, 247-257. Doi 10.11646/phytotaxa.224.3.3

Etayo J, Sancho LG. 2008 - Hongos liquenícolas del sur de sudamérica, especialmente de isla navarino (Chile). Bibliotheca Lichenologica, ISBN 978-3-443-58077-3.

Farr DF, Rossman AY. 2021 - Fungal Databases, U.S. National Fungus Collections, ARS, USDA. Retrieved from https://nt.ars-grin.gov/fungaldatabases/

Ferdinandez HS, Manamgoda DS, Udayanga D, Deshappriya N et al. 2021 - Molecular phylogeny and morphology reveal three novel species of Curvularia (Pleosporales, Pleosporaceae) associated with cereal crops and weedy grass hosts. Mycological Progress 20(4), 431-451. Doi 10.1007/s11557-021-01681-0

Ferraro LI. 2004 - Morphological diversity in the hyphophores of Gomphillaceae (Ostropales, lichenized Ascomycetes). Fungal Diversity 15, 153-169. Doi 10.1002/yea.1100

Flakus A, Kukwa M. 2012 - New records of lichenicolous fungi from Bolivia. Opuscula Philolichenum 11, 36-48.

Flakus A, Etayo J, Kukwa M, Flakus PR. 2016 - High diversity of lichenicolous fungi in the tropical Andes of Bolivia. In: The 8th IAL symposium lichens in deep time, Helsinki, Finland. IAL8 Abstracts. 182.

Flakus A, Etayo J, Miadlikowska J, Lutzoni F et al. 2019a - Biodiversity assessment of ascomycetes inhabiting Lobariella lichens in Andean cloud forests led to one new family, three new genera and 13 new species of lichenicolous fungi. Plant Fung Syst 64, 283-344. 
Doi 0.2478/pfs-2019-0022

Flakus A, Etayo J, Pérez-Ortega S, Kukwa M et al. 2019b - A new genus, Zhurbenkoa, and a novel nutritional mode revealed in the family Malmideaceae (Lecanoromycetes, Ascomycota). Mycologia 111, 593-611. Doi 10.1080/00275514.2019.1603500

Frisch A, Ohmura Y, Ertz D, Thor G. 2015 - Inoderma and related genera in Arthoniaceae with elevated white pruinose pycnidia or sporodochia. Lichenologist 47, 233-256.

Doi 10.1017/S0024282915000201

Fröhlich J, Hyde KD. 1999 - Biodiversity of palm fungi in the tropics: are global fungal diversity estimates realistic? Biodiversity \& Conservation 8(7), 977-1004.

Doi 10.1023/A:1008895913857

Glienke C, Pereira OL, Stringari D, Fabris J et al. 2011 - Endophytic and pathogenic Phyllosticta species, with reference to those associated with Citrus Black Spot. Persoonia 26, 47-56. Doi 10.3767/003158511X569169

Gomes RR, Glienke C, Videira SIR, Lombard L et al. 2013 - Diaporthe: a genus of endophytic, saprobic and plant pathogenic fungi. Persoonia 31, 1-41. Doi 10.3767/003158513X666844

Groenewald JZ, Nakashima C, Nishikawa J, Shin HD et al. 2013 - Species concepts in Cercospora: spotting the weeds among the roses. Studies in Mycology 75, 115-170.

Doi 10.3114/sim0012

Groenewald M, Groenewald JZ, Crous PW 2005 - Distinct species exist within the Cercospora apii morphotype. Phytopathology 95, 951-959. Doi 10.1094/PHYTO-95-0951

Guba EF. 1961 - Monograph of Pestalotia and Monochaetia; Harvard University Press: Cambridge, MA, USA. Doi 10.2307/3755860

Guivin MAC, Cerna MA, Abad JCG, Vallejos TA et al. 2020 - Paraglomus occidentale, a new arbuscular mycorrhizal fungus from the sources of the Amazon river in Peru, with a key to the Paraglomeromycetes species. Sydowia 72, 85-94.

Doi 10.12905/0380.sydowia72-2020-0085

Gweon HS, Oliver A, Taylor J, Booth T et al. 2015 - PIPITS: An automated pipeline for analyses of fungal internal transcribed spacer sequences from the Illumina sequencing platform. Methods in Ecology and Evolution 6, 973-980. Doi 10.1111/2041-210X.12399

Harris RC. 1973 - The corticolous pyrenolichens of the Great Lakes region. Michigan Botanist 12, 3-68.

Harris RC. 1995 - More Florida lichens. Published by the author.

Hashimoto A, Matsumura M, Hirayama K, Tanaka K. 2017 - Revision of Lophiotremataceae (Pleosporales, Dothideomycetes): Aquasubmersaceae, Cryptocoryneaceae, and Hermatomycetaceae fam. nov. Persoonia 39, 51-73. Doi 10.3767/persoonia.2017.39.03

Hawksworth DL. 1977 - Taxonomic and biological observations on the genus Lichenoconium (Sphaeropsidales). Persoonia 9(2), 159-198.

Hawksworth DL. 1991 - The fungal dimension of biodiversity: magnitude, significance, and conservation. Mycological Research 95, 641-655. Doi 10.1016/S0953-7562(09)80810-1

Hawksworth DL. 2001 - The magnitude of fungal diversity: the 1.5 million species estimate revisited. Mycological Research 105, 1422-1432. Doi 10.1017/S0953756201004725

Hawksworth DL, Lücking R. 2017 - Fungal diversity revisited: 2.2 to 3.8 million species. Microbiol Spectrum 5, 79-95. Doi 10.1128/microbiolspec.FUNK-0052-2016

Hawksworth DL, Poelt J. 1986 - Five additional genera of conidial lichen-forming fungi from Europe. Plant Systematics and Evolution 154(3), 195-211. Doi 10.1007/BF00990123

Hebert PDN, Cywinska A, Ball SL, de Waard JR. 2003 - Biological identifications through DNA barcodes. Proceedings of the Royal Society of London 270, 313-321.

Doi 10.1098/rspb.2002.2218

Hibbett DS, Ohman A, Glotzer D, Nuhn M et al. 2011 - Progress in molecular and morphological taxon discovery in Fungi and options for formal classification of environmental sequences. Fungal Biology Reviews 25(1), 38-47. Doi 10.1016/j.fbr.2011.01.001 
Hongsanan S, Hyde KD, Phookamsak R, Wanasinghe DN et al. 2020 - Refined families of Dothideomycetes: orders and families incertae sedis in Dothideomycetes. Fungal Diversity 105(1), 17-318. Doi 10.1007/s13225-020-00462-6

Hongsanan S, Jeewon R, Purahong W, Xie N et al. 2018 - Can we use environmental DNA as holotypes? Fungal Diversity 92(1), 1-30. Doi 10.1007/s13225-018-0404-X

http://www.worldfloraonline.org (Accessed on Sep 3, 2021)

https://www.cabi.org/isc/ (Accessed on Sep 3, 2021)

Hyde KD. 2001 - Where are the missing fungi? Does Hong Kong have any answers? Mycological Research 105, 1514-1518. Doi 10.1017/S0953756201225477

Hyde KD, Fröhlich J, Taylor JE. 1998 - Fungi from palms. XXXVI. Reflections on unitunicate ascomycetes with apiospores. Sydowia 50(1), 21-80.

Hyde KD, Jeewon R, Chen YJ, Bhunjun CS et al. 2020 - The numbers of fungi: is the descriptive curve flattening? Fungal Diversity 103(1), 219-271. Doi 10.1007/s13225-020-00458-2

Hyde KD, Norphanphoun C, Chen J, Dissanayake AJ et al. 2018 - Thailand's amazing diversity: up to $96 \%$ of fungi in northern Thailand may be novel. Fungal Diversity 93, 215-239.

Doi 10.1007/s13225-018-0415-7

Hyde KD, Tennakoon DS, Jeewon R, Bhat DJ et al. 2019 - Fungal diversity notes 1036-1150: taxonomic and phylogenetic contributions on genera and species of fungal taxa. Fungal Diversity 96(1), 1-242. Doi 10.1007/s13225-019-00429-2

Index Fungorum. 2021 - http://www.indexfungorum.org/names/names.asp. Accessed on: 03 Sep 2021.

Jayawardena RS, Hyde KD, Chethana KW, Daranagama DA et al. 2018 - Mycosphere notes 102168: Saprotrophic fungi on Vitis in China, Italy, Russia and Thailand. Mycosphere 9(1), 1114. Doi 10.5943/mycosphere/9/1/1

Jayawardena RS, Hyde KD, Damm U, Cai L et al. 2016 - Notes on currently accepted species of Colletotrichum. Mycosphere 7(8), 1192-260. Doi 10.1007/s13225-021-00484-8

Jayawardena RS, Hyde KD, Jeewon R, Ghobad-Nejhad M et al. 2019 - One stop shop II: taxonomic update with molecular phylogeny for important phytopathogenic genera: $26-50$. Fungal Diversity 94, 41-129. Doi 10.1007/s13225-019-00418-5

Jeewon R, Hyde KD. 2007 - Detection and diversity of fungi from environmental samples: traditional versus molecular approaches. In advanced techniques in soil microbiology. Springer, Berlin, Heidelberg 1-15. Doi 10.1007/978-3-540-70865-0_1

Jones EBG, Pang KL, Wahab MAA, Scholz B et al. 2019 - An online resource for marine fungi. Fungal Diversity 96(1), 347-433. Doi 10.1007/s13225-019-00426-5

Kalb K, Vězda A. 1988 - Neue oder bemerkenswerte Arten der Flechtenfamilie Gomphillaceae in der Neotropis. Bibliotheca Lichenologica 29, 1-80.

Karunarathna A, Działak P, Jayawardena RS, Karunarathna SC et al. 2021 - A novel addition to the Pezizellaceae (Rhytismatales, Ascomycota). Phytotaxa 480(3), 251-261.

Doi 10.11646/phytotaxa.480.3.4

Katoh K, Rozewicki J, Yamada KD. 2019 - MAFFT online service: multiple sequence alignment, interactive sequence choice and visualization. Briefings in Bioinformatics 20(4), 1160-1166. Doi 10.1093/bib/bbx108

Konstantinidis KT, Rosselló-Móra R, Amann R. 2017 - Uncultivated microbes in need of their own taxonomy. ISME J 11, 2399-2406. Doi 10.1038/ismej.2017.113

Konta S, Hongsanan S, Phillips AJ, Jones EB et al. 2016 - Botryosphaeriaceae from palms in Thailand II-two new species of Neodeightonia, N. rattanica and N. rattanicola from Calamus (rattan palm). Mycosphere 7(7), 950-61. Doi 10.5943/mycosphere/si/1b/6

Konta S, Maharachchikumbura SSN, Senanayake IC, Kenzie EHCM et al. 2020 - A new genus Allodiatrype, five new species and a new host record of diatrypaceous fungi from palms (Arecaceae). Mycosphere 11(1), 239-268. Doi 10.5943/mycosphere/11/1/4 
Koukol O, Delgado G, Hofmann TA, Piepenbring M. 2018 - Panama, a hot spot for Hermatomyces (Hermatomycetaceae, Pleosporales) with five new species, and a critical synopsis of the genus. IMA fungus 9(1), 107-41. Doi 10.5598/imafungus.2018.09.01.08

Koukol O, Delgado G. 2019 - Do not forget Africa - revision of fungarium collections at Kew revealed a new species of Hermatomyces (Hermatomycetaceae, Pleosporales). Nova hedwigia 109, 413-423.

Lawrey JD, Diederich P, Nelsen MP, Sikaroodi M et al. 2011- The obligately lichenicolous genus Lichenoconium represents a novel lineage in the Dothideomycetes. Fungal Biology 115, 176187. Doi 10.1016/j.funbio.2010.12.002

Leão-Ferreira SM, Gusmão LFP, Castañeda RF. 2013 - Conidial fungi from the semi-arid Caatinga biome of Brazil. Three new species and new records. Nova Hedwigia 96, 479-494.

Doi 10.1127/0029-5035/2013/0084

Li WJ, McKenzie EH, Liu JK, Bhat DJ et al. 2020 -Taxonomy and phylogeny of hyaline-spored coelomycetes. Fungal Diversity 100, 279-801. Doi 10.1007/s13225-020-00440-y

Liu YJ, Whelen S, Hall BD. 1999 - Phylogenetic relationships among ascomycetes: evidence from an RNA polymerse II subunit. Molecular Biology \& Evolution 16(12), 1799-1808.

Doi 10.1093/oxfordjournals.molbev.a026092

Liew ECY, Aptroot A, Hyde KD. 2000 - Phylogenetic significance of the pseudoparaphyses in Loculoascomycete taxonomy. Molecular Phylogeny and Evolution 16, 392-402.

Doi 10.1006/mpev.2000.0801

Locquin M. 1984 - Mycologie générale et structurale: 202. Masson, Paris.

Lombard L, Crous PW, Wingfield BD, Wingfield MJ. 2010 - Phylogeny and systematics of the genus Calonectria. Studies in Mycology 66, 31-69. Doi 10.3114/sim.2010.66.03

Lücking R. 2008 - Foliicolous lichenized fungi. Flora neotropica 103, 1-867.

Lücking R, Aime MC, Robbertse B, Miller AN et al. 2021 - Fungal taxonomy and sequence-based nomenclature. Nature Microbiology 6(5), 540-548. Doi 10.1038/s41564-021-00888-x

Lücking R, Aime MC, Robbertse B, Miller AN et al. 2020 - Unambiguous identification of fungi: where do we stand and how accurate and precise is fungal DNA barcoding? IMA fungus 11(1), 1-32. Doi 10.1186/s43008-020-00033-Z

Lücking R, Aptroot A, Umaña, L, Chaves J et al. 2006 - A first assessment of the Ticolichen biodiversity inventory in Costa Rica: the genus Gyalideopsis and its segregates (Ostropales: Gomphillaceae), with a world-wide key and name status checklist. Lichenologist 38, 131160. Doi 10.1017/S0024282905005657

Lücking R, Hawksworth DL. 2018 - Formal description of sequence-based voucherless Fungi: Promises and pitfalls, and how to resolve them. IMA fungus 9, 143-165.

Doi 10.5598/imafungus.2018.09.01.09.

Lücking R, Sérusiaux E, Maia LC, Pereira CG. 1998 - A revision of the names of foliicolous lichenized fungi published by Batista and co-workers between 1960 and 1975. Lichenologist 30, 121-191. Doi 10.1006/lich.1997.0117

Luo Y, Wei X, Yang S, Gao YH et al. 2020 - Fungal diversity in deep-sea sediments from the Magellan seamounts as revealed by a metabarcoding approach targeting the ITS2 regions. Mycology 11, 214-229. Doi 10.1080/21501203.2020.1799878.

Luo ZL, Hyde KD, Liu JK, Maharachchikumbura SSN et al. 2019 - Freshwater Sordariomycetes. Fungal Diversity 99, 451-660. Doi 10.1007/s13225-019-00438-1

Maharachchikumbura SSN, Chen Y, Ariyawansa HA, Hyde KD et al. 2021 - Integrative approaches for species delimitation in Ascomycota. Fungal Diversity 109, 155-179.

Doi 10.1007/s13225-021-00486-6

Malme GOA. 1935 - Das kampylidium, ein verkanntes Fortpflanzungsorgan der Flechten. Svensk Botanisk TidskriftlSvensk Bot. Tidskr 29, 302-305

Mapook A, Hyde KD, Kenzie EHM, Jones EBG et al. 2020 - Taxonomic and phylogenetic contributions to fungi associated with the invasive weed Chromolaena odorata (Siam weed). Fungal Diversity 101(1), 1-75. Doi 10.1007/s13225-020-00444-8 
Margulies M, Egholm M, Altman WE, Attiya S et al. 2005 - Genome sequencing in microfabricated high-density picolitre reactors. Nature 437, 376-380.

Doi 10.1038/nature03959

Matzer M. 1996 - Lichenicolous ascomycetes with fissitunicate asci on foliicolous lichens. Mycological Papers 171, i-x, 1-202.

Mayden RL. 1997 - A hierarchy of species concepts: The denouement in the saga of the species problem. In Species: The Units of Biodiversity (M. F. Claridge, H. A. Dawah, and M. R. Wilson, Eds.) Chapman \& Hall, London 381-424.

Muggia L, Mancinelli R, Tønsberg T, Jablonska J et al. 2017 - Molecular analyses uncover the phylogenetic placement of the lichenized hyphomycetous genus Cheiromycina. Mycologia 109, 588-600. Doi 10.1080/00275514.2017.1397476

Muggia L, Coleine C, De Carolis R, Cometto A, Selbmann L 2021 - Antarctolichenia onofrii gen. nov. sp. nov. from Antarctic endolithic communities untangles the evolution of rockinhabiting and lichenized fungi in Arthoniomycetes. Journal of Fungi 7(11), 935.

Doi 10.3390/jof7110935

Murray RGE, Stackebrandt E. 1995 - Taxonomic note: implementation of the provisional status Candidatus for incompletely described procaryotes. International Journal of Systematic and Evolutionary Microbiology 45, 186-187. Doi 10.1099/00207713-45-1-186

Myers N, Mittermeier RA, Mittermeier CG, Da Fonseca GA, Kent J. 2000 - Biodiversity hotspots for conservation priorities. Nature 403(6772), 853-858. Doi 10.1038/35002501

Nag Raj TR. 1993 - Coelomycetous anamorphs with appendage-bearing conidia. Mycologue publications.

Norphanphoun C, Hongsanan S, Gentekaki E, Chen YJ et al. 2020 - Diferentiation of species complexes in Phyllosticta enables better species resolution. Mycosphere 11, 2542-2628.

Doi 10.5943/mycosphere/11/1/16

Nuankaew S, Suetrong S, Wutikhun T, Pinruan U. 2019 - Hermatomyces trangensis sp. nov., a new dematiaceous hyphomycete (Hermatomycetaceae, Pleosporales) on sugar palm in Thailand. Phytotaxa 391, 277-288. Doi 10.11646/phytotaxa.391.5.1

Nylander JA, Ronquist F, Huelsenbeck JP, Nieves-Aldrey J. 2004 - Bayesian phylogenetic analysis of combined data. Systematic Biology 53(1), 47-67. Doi 10.1080/10635150490264699

Pan M, Zhu H, Bezerra JD, Bonthond G et al. 2019 - Botryosphaerialean fungi causing canker and dieback of tree hosts from Mount Yudu in China. Mycological Progress (11), 1341-61.

Doi 10.1007/s11557-019-01532-z

Pem D, Jeewon R, Chethana KWT et al. 2021 - Species concepts of Dothideomycetes: classification, phylogenetic inconsistencies and taxonomic standardization. Fungal Diversity 109, 283-319. Doi 10.1007/s13225-021-00485-7

Petrak F, Sydow H. 1927 - Die Gattungen der Pyrenomyzeten, Sphaeropsideen und Melanconieen. 1. Die phaeosporen Sphaeropsideen und die Gattung Macrophoma. Repertorium Specierum Novarum Regni Vegetabilis Beihefte 42, 1-551.

Phillips AJL, Alves A, Abdollahzadeh J, Slippers B. 2013 - The Botryosphaeriaceae: genera and species known from culture. Studies in Mycology 76, 51-167. Doi 10.3114/sim0021

Phoulivong S, Cai L, Chen H, McKenzie EHC et al. 2010 - Colletotrichum gloeosporioides is not a common pathogen on tropical fruits. Fungal Diversity 44(1), 33-43.

Doi 10.1007/s13225-010-0046-0

Phukhamsakda C, Bhat DJ, Hongsanan S, Tibpromma S et al. 2017 - Magnicamarosporium diospyricola sp. nov. (Sulcatisporaceae) from Thailand. Mycosphere 8(4), 512-520.

Doi 10.5943/mycosphere/8/4/3

Phukhamsakda C, McKenzie EH, Phillips AJ, Jones EBG et al. 2020 - Microfungi associated with Clematis (Ranunculaceae) with an integrated approach to delimiting species boundaries. Fungal Diversity 102(1), 1-203. Doi 10.1007/s13225-020-00448-4

Printzen C. 2007 - New records of Cheiromycina species, a genus of lichenized hyphomycetes, with $C$. reimeri sp. nov. and a revised key to the species. Nova Hedwigia 84, 261-267. 
Doi 10.1127/0029-5035/2007/0084-0261

Quan Y, Muggia L, Moreno LF, Jones EBG et al. 2020 - A re-evaluation of the Chaetothyriales using criteria of comparative biology. Fungal Diversity 103, 47-85.

Doi 10.1007/s13225-020-00452-8

Rajeshkumar KC, Braun U, Groenewald JZ, Lad SS et al. 2021 - Phylogenetic placement and reassessment of Asperisporium pongamiae as Pedrocrousiella pongamiae gen. et comb. nov. (Mycosphaerellaceae). Fungal Systematics and Evolution 7, 165.

Doi 10.3114/fuse.2021.07.08

Rajeshkumar KC, Singh SK. 2012 - Manoharachariella indica sp. nov. from the Western Ghats, India. Mycotaxon 120(1), 43-8. Doi 10.5248/120.43

Rajeshkumar KC, Yilmaz N, Marathe SD, Seifert KA. 2019 - Morphology and multigene phylogeny of Talaromyces amyrossmaniae, a new synnematous species belonging to the section Trachyspermi from India. MycoKeys (45), 41. Doi 10.3897/mycokeys.45.32549

Rannala B, Yang Z. 1996 - Probability distribution of molecular evolutionary trees: a new method of phylogenetic inference. Journal of Molecular Eevolution 43(3), 304-11.

Doi 10.1007/BF02338839

Rashmi M, Kushveer JS, Sarma VV. 2019 - A worldwide list of endophytic fungi with notes on ecology and diversity. Mycosphere 10(1), 798-1079. Doi 10.5943/mycosphere/10/1/19

Rehner S. 2001 - Primers for elongation factor 1- $\alpha$ (EF1- $\alpha)$. Available from: http://ocid. NACSE.ORG/research/deephyphae/EF1primer. pdf (Accessed on September 30, 2020)

Rehner SA, Samuels GJ. 1994 - Taxonomy and phylogeny of Gliocladium analysed from nuclear large subunit ribosomal DNA sequences. Mycological Resreach 98, 625-634.

Doi 10.1016/S0953-7562(09)80409-7

Ren GC, Wanasinghe DN, Monkai J, Mortimer PE. 2021 - Novel saprobic Hermatomyces species (Hermatomycetaceae, Pleosporales) from China (Yunnan province) and Thailand. Mycokeys 82, 57-79. Doi 10.3897\%2Fmycokeys.82.67973

Ronquist F, Huelsenbeck JP. 2003 - MrBayes 3: Bayesian phylogenetic inference under mixed models. Bioinformatics 12, 1572-1574. Doi 10.1093/bioinformatics/btg180

Ruibal C, Gueidan C, Selbmann L, Gorbushina AA et al. 2009 - Phylogeny of rock-inhabiting fungi related to Dothideomycetes. Studies in Mycology 64, 123-133.

Doi 10.3114/sim.2009.64.06

Ruibal C, Platas G, Bills GF. 2005 - Isolation and characterization of melanized fungi from limestone formations in Mallorca. Mycological Progress 4(1), 23-38.

Doi 10.1007/s11557-006-0107-7

Rupcic Z, Chepkirui C, Hernández-Restrepo M, Crous PW et al. 2018 - New nematicidal and antimicrobial secondary metabolites from a new species in the new genus, Pseudobambusicola thailandica. MycoKeys 1, 1-23. Doi 10.3897/mycokeys.33.23341

Santesson R. 1952 - Foliicolous lichens I. A revision of the taxonomy of the obligately foliicolous, lichenized fungi. Symbolae Botanicae Upsalienses 12(1), 1-590.

Selbmann L, De Hoog GS, Mazzaglia A, Friedmann EI et al. 2005 - Fungi at the edge of life: cryptoendolithic black fungi from Antarctic desert. Studies in Mycology 51(1), 1-32.

Doi 10.1111/j.1439-0507.2005.01118.x

Selbmann L, De Hoog GS, Zucconi L, Isola D et al. 2008 - Drought meets acid: three new genera in a dothidealean clade of extremotolerant fungi. Studies in Mycology 61, 1-20.

Doi 10.3114/sim.2008.61.01

Sérusiaux E. 1986 - The nature and origin of campylidia in lichenized fungi. Lichenologist 18, 135. Doi 10.1017/S0024282986000038

Sérusiaux E, Lücking R. 2003 - The lichen genus Caprettia Bat. \& H. Maia (Monoblastiaceae). Bibliotheca Lichenologica 86, 161-176.

Shendure J, Porreca GJ, Reppas NB, Lin X et al. 2005 - Accurate multiplex polony sequencing of an evolved bacterial genome. Science 309(5741), 1728-1732. Doi 10.1126/science.1117389 
Shivas RG, Cai L. 2011 - Cryptic fungal species unmasked. Microbiology Australia 33, 36-37. Doi 10.1071/ma12036

Silvestro D, Michalak I. 2012 - raxmlGUI: a graphical front - end for RAxML. Organisms Diversity \& Evolution 12(4), 335-337. Doi 10.1007/s13127-011-0056-0

Singh P, Raghukumar C, Verma P, Shouche Y. 2010 - Fungal community analysis in the deep-sea sediments of the Central Indian basin by culture-independent approach. Microbial Ecology 61, 507-517. Doi 10.1007/s00248-010-9765-8

Smith CW, Aptroot A, Coppins BJ, Fletcher A et al. 2009 - The lichens of Great Britain and Ireland. British Lichen Society, London 1046.

Smith RJ, Muir RD, Walpole MJ, Balmford A et al. 2003 - Governance and the loss of biodiversity. Nature 426(6962), 67-70. Doi 10.1038/nature02025

Species Fungorum. 2021 - http://www.speciesfungorum.org/names/names.asp, accessed date 7th September 2021.

Spegazzini CL. 1911 - Mycetes Argentinenses. Series V. Anales Museo Nacional de Historia Natural Buenos Aires 3(13), 446.

Stamatakis A. 2014 - RAxML version 8: a tool for phylogenetic analysis and post-analysis of large phylogenies. Bioinformatics 30(9), 1312-1313. Doi 10.1093/bioinformatics/btu033

Sterflinger K, de Hoog GS, Haase G. 1999 - Phylogeny and ecology of meristematic ascomycetes. Studies in Mycology 43, 5-22.

Sterflinger K, Prillinger H. 2001 - Molecular taxonomy and biodiversity of rock fungal communities in an urban environment (Vienna, Austria). Antonie van Leeuwenhoek 80(3-4), 275-286. Doi 10.1023/A:1013060308809

Su L, Guo L, Hao Y, Xiang M et al. 2015 - Rupestriomyces and Spissiomyces, two new genera of rock-inhabiting fungi from China. Mycologia 107(4), 831- 844. Doi 10.3852/14-305

Suija A, Kaasalainen U, Kirika PM, Rikkinen J. 2018 - Taitaia, a novel lichenicolous fungus in tropical montane forests in Kenya (East Africa). Lichenologist 50(2), 173-184.

Doi 10.1017/S0024282918000026

Suija A, Zhurbenko MP, Stepanchikova IS, Himelbrant DE et al. 2020 - Kukwaea pube scens gen. et sp. nova (Helotiales, incertae sedis), a new lichenicolous fungus on Cetraria islandica, and a key to the lichenicolous fungi occurring on Cetraria s. str. Phytotaxa 459(1), 39-50.

Doi 10.11646/phytotaxa.459.1

Summerell BA, Laurence MH, Liew EC, Leslie JF. 2010 - Biogeography and phylogeography of Fusarium: a review. Fungal Diversity 44(1), 3-13. Doi 10.1007/s13225-010-0060-2

Summerell BA, Leslie JF. 2011 - Fifty years of Fusarium: how were nine species ever enough? Fungal Diversity 50, 135-144. Doi 10.1007/s13225-011-0132-y

Summerell BA, Leslie JF, Liew EC, Laurence MH et al. 2011 - Fusarium species associated with plants in Australia. Fungal Diversity 46(1), 1-27. Doi 10.1007/s 13225-010-0075-8

Sun JZ, Liu XZ, McKenzie EH, Jeewon R. 2019 - Fungicolous fungi: terminology, diversity, distribution, evolution, and species checklist. Fungal Diversity 95(1), 337-430.

Doi 10.1007/s13225-019-00422-9

Sun W, Su L, Yang S, Sun J et al. 2020 - Unveiling the hidden diversity of rock-inhabiting fungi: Chaetothyriales from China. Journal of Fungi 6(4), 187. Doi 10.3390/jof6040187

Sutton BC. 1980 - The Coelomycetes. Fungi imperfecti with pycnidia, acervuli and stromata. Commonwealth Mycological Institute, Kew.

Tamura K, Stecher G, Peterson D, Filipski A et al. 2013 - MEGA6: molecular evolutionary genetics analysis version 6.0. Molecular Biology and Evolution 30(12), 2725-2729.

Doi 10.1093/molbev/mst197

Tanaka K, Hirayama K, Yonezawa H, Sato G et al. 2015 - Revision of the Massarineae (Pleosporales, Dothideomycetes). Studies in Mycology 82, 75-136.

Doi 10.1016/j.simyco.2015.10.002 
Taylor JE, Hyde KD, Jones EB. 1999 - Endophytic fungi associated with the temperate palm, Trachycarpus fortunei, within and outside its natural geographic range. New Phytologist 142(2), 335-346. Doi 10.1046/j.1469-8137.1999.00391.x

Taylor JW, Jacobson DJ, Kroken S, Kasuga T et al. 2000 - Phylogenetic species recognition and species concepts in fungi. Fungal Genetics and Biology 31(1), 21-32.

Doi 10.1006/fgbi.2000.1228

Tedersoo L, Bahram M, Põlme S, Kõljalg U et al. 2014 - Global diversity and geography of soil fungi. Science 346, 1256688. Doi 10.1126/science.1256688.

Tedersoo L, Bahram M, Puusepp R, Nilsson H et al. 2017 - Novel soil-inhabiting clades fill gaps in the fungal tree of life. Microbiome 5, 1-10. Doi 10.1186/s40168-017-0259-5.

Tedersoo L, Mikryukov V, Anslan S. et al. 2021 - The Global soil mycobiome consortium dataset for boosting fungal diversity research. Fungal Diversity 111, 573-588.

Doi 10.1007/s13225-021-00493-7

Tedersoo L, Anslan S, Bahram M, Kõljalg U, Abarenkov K. 2020 - Identifying the 'unidentified'fungi: a global-scale long-read third-generation sequencing approach. Fungal Diversity 103(1), 273-293. Doi 10.1007/s13225-020-00456-4

Tennakoon DS, Gentekaki E, Jeewon R, Kuo CH et al. 2021 - Life in leaf litter: Fungal community succession during decomposition. Mycosphere 12, 406-429.

Thambugala KM, Wanasinghe DN, Phillips AJ, Camporesi E et al. 2017 - Mycosphere notes 1-50: grass (Poaceae) inhabiting Dothideomycetes. Mycosphere 8(4), 697-796.

Doi 10.5943/mycosphere/8/4/13

Theissen F, Sydow H. 1915 - Die Dothideales. Kritisch-systematische originaluntersuchungen. Annales Mycologici 13(3-4), 147-746.

Thines M, Crous PW, Aime MC, Aoki T et al. 2018 - Ten reasons why a sequence-based nomenclature is not useful for fungi anytime soon. IMA fungus 9(1), 177-183.

Doi 10.5598/imafungus.2018.09.01.11

Tibpromma S, Bhat J, Doilom M, Lumyong S et al. 2016 -Three new Hermatomyces species (Lophiotremataceae) on Pandanus odorifer from Southern Thailand. Phytotaxa 275(2), 127 139. Doi 10.11646/phytotaxa.275.2.4

Tibpromma S, Hyde KD, Bhat JD, Mortimer PE et al. 2018a - Identification of endophytic fungi from leaves of Pandanaceae based on their morphotypes and DNA sequence data from southern Thailand. MycoKeys 33, 25-67. Doi 10.3897/mycokeys.33.23670

Tibpromma S, Hyde KD, McKenzie EH, Bhat DJ et al. 2018b - Fungal diversity notes 840-928: micro-fungi associated with Pandanaceae. Fungal Diversity 93(1), 1-60.

Doi 10.1007/s13225-018-0408-6

Turland NJ, Wiersema JH, Barrie FR, Greuter W et al. 2018 - International Code of Nomenclature for algae, fungi, and plants (Shenzhen Code) adopted by the Nineteenth International Botanical Congress Shenzhen, China, July 2017. Regnum Vegetable 159, 1-254.

Doi 10.12705/Code.2018

Udayanga D, Castlebury LA, Rossman AY, Chukeatirote E et al. 2014a - Insights into the genus Diaporthe: phylogenetic species delimitation in the $D$. eres species complex. Fungal Diversity 67, 203-229. Doi 10.1007/s13225-014-0297-2

Udayanga D, Castlebury LA, Rossman AY, Hyde KD. 2014b - Species limits in Diaporthe: molecular re-assessment of D. citri, D. cytosporella, D. foeniculina and D. rudis. Persoonia 32, 83-101. Doi 10.3767/003158514X679984

Udayanga D, Liu X, Crous PW, McKenzie EH et al. 2012 - A multi-locus phylogenetic evaluation of Diaporthe (Phomopsis). Fungal Diversity 56(1), 157-71. Doi 10.1007/s13225-012-0190-9

Van Niekerk JM, Groenewald JZ, Farr DF, Fourie PH et al. 2005 - Reassessment of Phomopsis species on grapevines. Australasian Plant Pathology 34(1), 27-39. Doi 10.1071/AP04072

Vilgalys R, Hester M. 1990 - Rapid genetic identification and mapping of enzymatically amplified ribosomal DNA from several Cryptococcus species. Journal of Bacteriology 172, 4238-4246. Doi 10.1128/jb.172.8.4238-4246.1990 
Wanasinghe DN, Jeewon R, Jones EBG, Boonmee S et al. 2018b - Novel palmicolous taxa within Pleosporales: multigene phylogeny and taxonomic circumscription. Mycological Progress 17, 571-590. Doi 10.1007/s11557-018-1379-4

Wanasinghe DN, Phukhamsakda C, Hyde KD, Jeewon R et al. 2018a - Fungal diversity notes 709839: taxonomic and phylogenetic contributions to fungal taxa with an emphasis on fungi on Rosaceae. Fungal Diversity 89(1), 1-236. Doi 10.1007/s13225-018-0395-7

Wang X, Chen G, Huang F, Zhang J et al. 2012 - Phyllosticta species associated with citrus diseases in China. Fungal Diversity 52(1), 209-224. Doi 10.1007/s13225-011-0140-y

White JR, Maddox C, White O, Angiuoli SV, Fricke WF. 2013 - CloVR-ITS: automated internal transcribed spacer amplicon sequence analysis pipeline for the characterization of fungal microbiota. Microbiome 1(1), 1-11. Doi 10.1186/2049-2618-1-6

White TJ, Bruns T, Lee J, Taylor SB. 1990 - Amplification and direct sequencing of fungal ribosomal RNA genes for phylogenetics. In: Innis MA, Gelfand DH, Sninsky JJ, White TJ (eds) PCR protocols: a guide to methods and applications. Academic, San Diego 315-322.

Wijayawardene NN, Hyde KD, Wanasinghe DN, Papizadeh M et al. 2016 - Taxonomy and phylogeny of dematiaceous coelomycetes. Fungal Diversity 77(1), 1-316.

Doi 10.1007/s13225-016-0360-2

Wijayawardene NN, Bahram M, Sánchez-Castro I, Dai D-Q et al. 2021a - Current insight into culture-dependent and culture-independent methods in discovering Ascomycetous Taxa. Journal of Fungi 7, 703. Doi 10.3390/jof7090703

Wijayawardene NN, Hyde KD, Anand G, Dissanayake LS et al. 2021b - Towards incorporating asexually reproducing fungi in the natural classification and notes for pleomorphic genera. Mycosphere 12(1), 238-405. Doi 10.5943/mycosphere/12/1/4

Wijayawardene NN, Phillips AJL, Pereira DRS, Dai DQ, Aptroot A. 2021c - Forecasting population dynamics reflecting the number of species of asexually reproducing fungi. Fungal Diversity (submitted).

Wijayawardene NN, Rajakaruna S, Dai DQ, Jayasekara S et al. 2021d - Necessity of a National Fungarium and a Culture Collection for Fungi in Sri Lanka. Chiang Mai Jounal of Science (accepted).

Wikee S, Udayanga D, Crous PW, Chukeatirote E et al. 2011 - Phyllosticta - an overview of current status of species recognition. Fungal Diversity 51(1), 43-61.

Doi 10.1007/s13225-011-0146-5

Wollenzien U, De Hoog GS, Krumbein W, Uijthof JMJ. 1997 - Sarcinomyces petricola, a new microcolonial fungus from marble in the Mediterranean basin. Antonie van Leeuwenhoek 71(3), 281-288. Doi 10.1023/A:1000157803954

Yeshitela K, Fischer E, Killmann D, Sérusiaux E. 2009 - Aspidothelium hirsutum (Thelenellaceae) and Caprettia goderei (Monoblastiaceae), two new species of foliicolous lichens from Ethiopia and Kenya. Bryologist 112(4), 850-855. Doi 10.1639/0007-2745-112.4.850

Zalar P, Novak M, de Hoog GS, Gunde-Cimerman N. 2011 - Dishwashers-a man-made ecological niche accommodating human opportunistic fungal pathogens. Fungal Biology 115, $997-$ 1007. Doi 10.1016/j.funbio.2011.04.007

Zhaxybayeva O, Gogarten JP, Charlebois RL, Doolittle WF et al. 2006 - Phylogenetic analyses of cyanobacterial genomes: quantification of horizontal gene transfer events. Genome Research 16(9), 1099-1108. Doi 10.1101/gr.5322306 